Portland State University

PDXScholar

1988

\title{
Limited horizons on the Oregon frontier : East Tualatin Plains and the town of Hillsboro, Washington County, 1840-1890
}

Richard P. Matthews

Portland State University

Follow this and additional works at: https://pdxscholar.library.pdx.edu/open_access_etds

Part of the History Commons

Let us know how access to this document benefits you.

Recommended Citation

Matthews, Richard P., "Limited horizons on the Oregon frontier : East Tualatin Plains and the town of Hillsboro, Washington County, 1840-1890" (1988). Dissertations and Theses. Paper 3808.

https://doi.org/10.15760/etd.5692

This Thesis is brought to you for free and open access. It has been accepted for inclusion in Dissertations and Theses by an authorized administrator of PDXScholar. Please contact us if we can make this document more accessible: pdxscholar@pdx.edu. 
AN ABSTRACT OF THE THESIS OF Richard P. Matthews for the Master of Arts in History presented 4 November, 1988.

Title: Limited Horizons on the oregon Frontier: East Tualatin Plains and the Town of Hillsboro, washingtor county, $1840-1890$

APPROVED BY MEMBERS OF THE THESIS COMMITTEE:

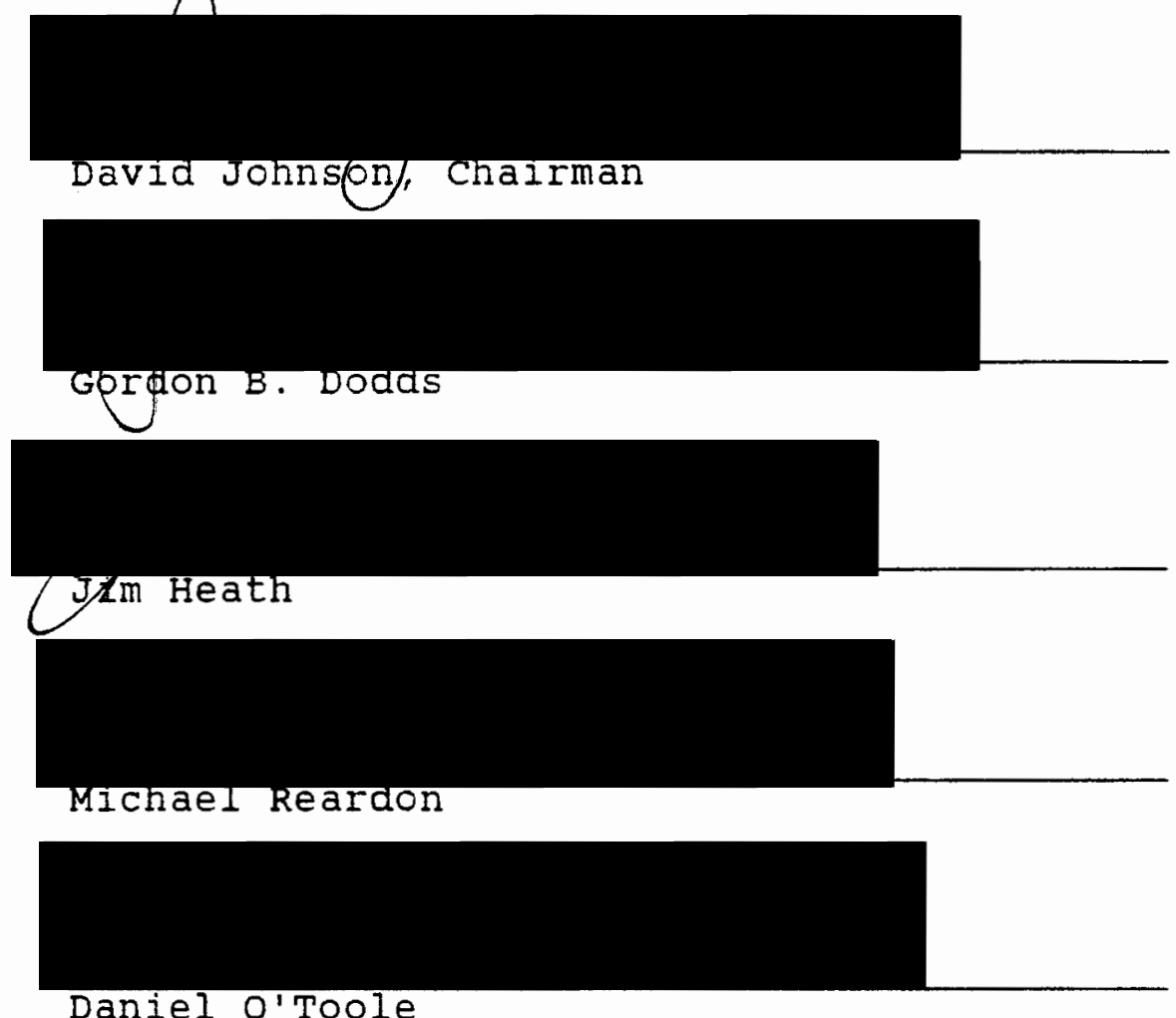

The evolution of the small towns that originated in Oregon's settlement communities remains undocumented in the literature of the state's history for the most part. Those 
accounts that do exist are ofter amateurish, and fail to establish the social and economic links between oregon's frontier towns to the agricultural communities in which they appeared. The purpose of the thesis is to investigate an early settlement community and the small town that grew up in its midst in order to better understand the ideological relationship between farmers and townsmen that helped shape oregon's small towns.

A thorough history of East Tualatin Plains does not exist. A profile of the community had to be constructed from census records, diaries and letters, land claim survey maps, social and religious organizational records and newspapers. The historic record of Hillsboro is even more impoverished. The early history of the town had to be pieced together from real estate transactions, credit records of early businesses and newspapers. After incorporation, the town records were helpful, along with newspapers and the surviving records of a few of the town's social and religious organizations.

Analysis of census, real estate and financial data along with a quantified interpretation of diaries and other personal information revealed an enlightening profile of farmers and townsmen. The community of East Tualatin Plains and its town of Hillsboro was inhabited by persistent settlers whose economic aspirations were greatly limited by closely held common social values. Family, church and 
community were much more important than economic gain to the people of East Tualatin Plains and Hillsboro. They worked together for over 100 years to insure the preservation of those values. 
LIMITED HORIZONS ON THE OREGON ERONTIER:

EAST TUALATIN PLAINS AND THE TOWN OF HILLSBORO, WASHINGTON COUNTY, $1840-1890$

by

RICHARD P. MATTHEWS

A thesis submitted in partial fulfillment of the requirements for the degree of

\author{
MASTER OF ARTS \\ in \\ HISTORY
}

Portland state University

1988 
TO THE OFFICE OF GRADUATE STUDIES:

The members of the committee approve the thesis of Richard P. Matthews, presented 4 November, 1988.

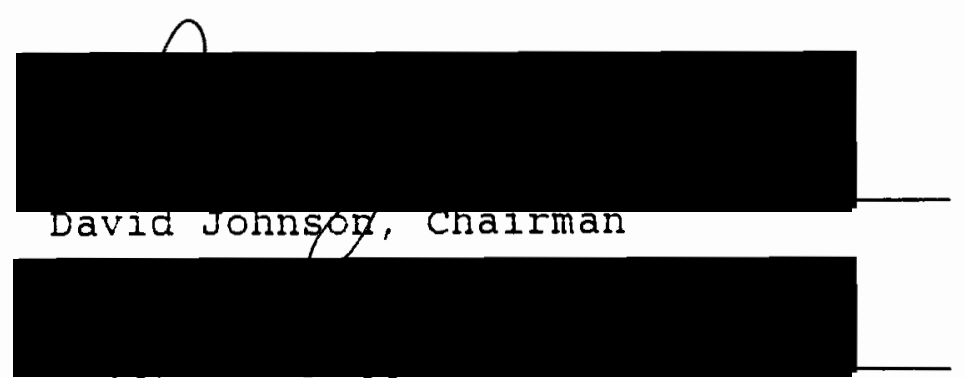

Gord $\phi$ n B. Dodds

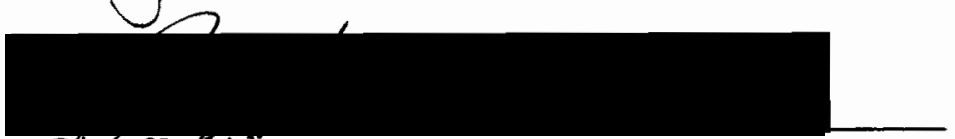

Jizn Heath

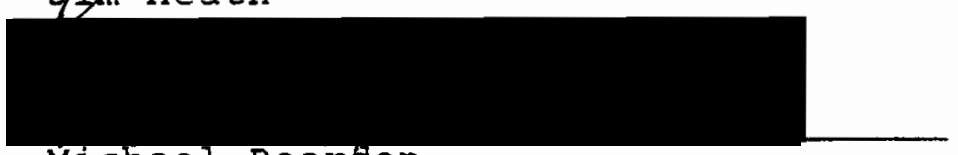

Michael Rearaon

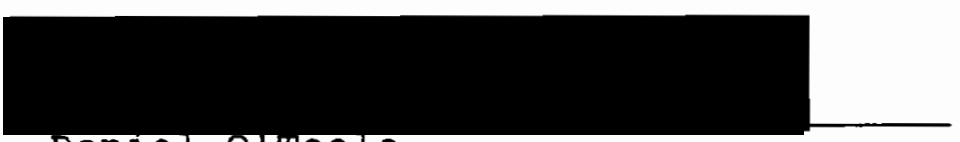

Daniel orroole

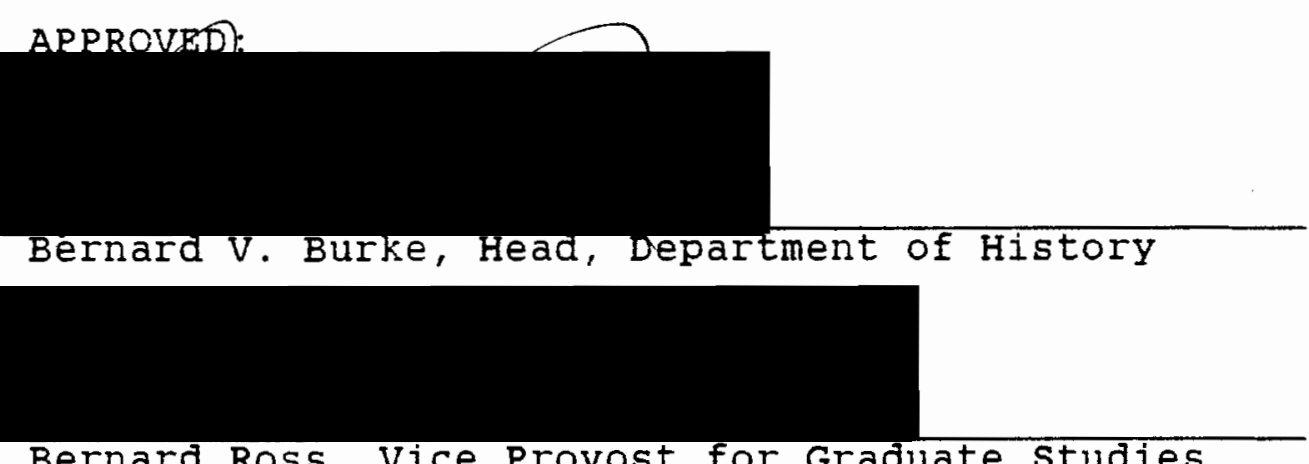

Bernard Ross, Vice Provost for Graduate studies 
TABLE OF CONTENTS

PAGE

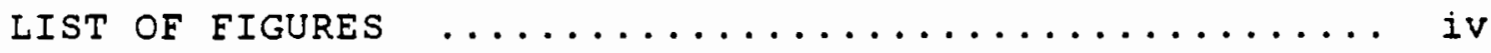

LIST OF TABLES $\ldots \ldots \ldots \ldots \ldots \ldots \ldots \ldots \ldots \ldots \ldots \ldots \ldots \ldots \ldots \ldots$

CHAPTER

I INTRODUCTION $\ldots \ldots \ldots \ldots \ldots \ldots \ldots \ldots \ldots \ldots$

II THE HISTORIC LANDSCAPE OF THE TUALATIN VALLEY . 6

III THE SETTLEMENT OF EAST TUALATIN PLAINS $\ldots \ldots \ldots 16$

IV SETTLEMENT CLUSTERING AND THE DEVELOPMENT OF EAST TUALATIN PLAINS NEIGHBORHOODS ........ 39

$\mathrm{V}$ LAND AND COMMUNITY AT EAST TUALATIN PLAINS $\ldots 52$

VI THE ECONOMY OF EAST TUALATIN PLAINS $\ldots \ldots \ldots 77$

VII COUNTY SEAT AND PIONEER TONN: HILLSBORO,

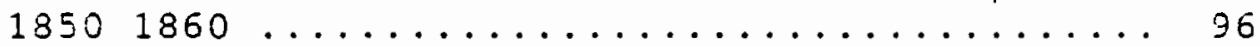

VIII HILLSBORO'S LIMITED AMBITIONS: $1860-1890 \ldots 115$

IX CONCLUSION ..................... 134

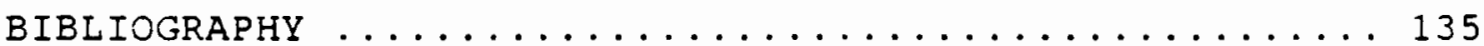




\section{IIST OF EIGURES}

FIGURE

PAGE

1. East Tualatin Plains Prairie and Swamplands .... 11

2. Willamette valley, $1851 \ldots \ldots \ldots \ldots \ldots \ldots$

3. Donation Land Claim Patterns, East Tualatin Plains,

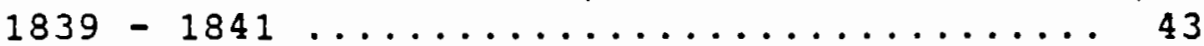

4. Donation Land Claim Patterns, East Tualatin Plains,

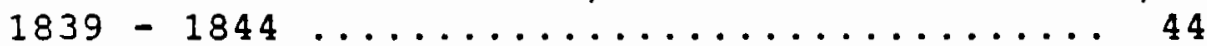

5. Donation Land Claim Patterns, East Tualatin Plains,

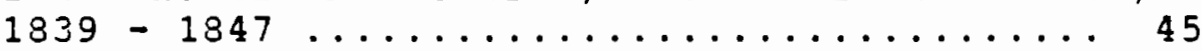

6. Donation Land Claim Patterns, East Tualatin Plains,

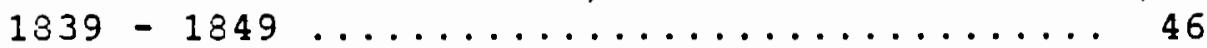

7. Donation Land Claim Patterns, East Tualatin Plains,

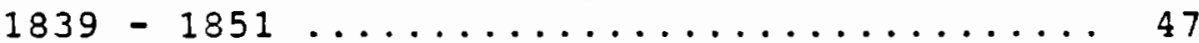

8. Cultirated Land and structures, East Tualatin

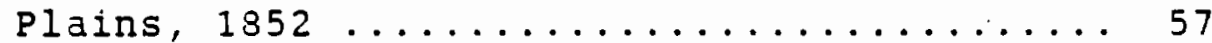




\section{LIST OF TABLES}

TAELE

PAGE

1. East Tualatin plains Population in $1850 \ldots \ldots 32$ 
CHAPTER I

INTRODUCTION

The relationship between rural communities and the towns that grew up in their midst during the settlement era in the Northern willamette valley has yet to be explored in deta1l. The early history of one of these communities, East Tualatin Plains and its town of Hillsboro, provides a measure of understanding as to how the economic and social needs of a rural farming community during the settlement era related to the growth of commerce in the larger context of oregon's urban frontier.

Historians of the frontier have focused on the role of the city in the development of the west, but not as much on the small town. ${ }^{1}$ Earl Pomeroy, in his classic work, The Pacific slope, stated that urban easterners and their cities dominated the west. They established an extractive colonial economy based on a few cities which they built and ran. Southerners and middle westerners dominated the rural areas. The degree of independence of the rural areas from the urban

${ }^{1}$ Earl Pomeroy, "The Urban Frontier of the Far west", The Frontier Challenge, ed. J.G. Clark (Lawrence, Kansas, 1971). Gerald D. Nash, The American west in the Twentieth Century. A short History of an Urban oasis, (Albuquerque, N.M.: University of New Mexico Press, 1977). Richard C. Wade, The Urban Erontier. The Rise of western Cities, 17901830, (Cambridge, Mass.: Harvard University Press, 1959). 
easterners depended on the relative autonomy of their local economies.

Small towns played an important role in connecting the urban and rural frontiers. Barbara Ruth Baily's study of the development of small towns in Eastern oregon is one of the first surveys to address the subject in terms of oregon history. Her book provides a useful definition of a frontier or pioneer town:

...an unplatted community is considered a town if it contained a post office, a store, a cluster of houses and several streets. In other words, it had to be a center with commercial and service functions, a resident population and something resembling the layout of a town. ${ }^{2}$

Baily goes on to divide pioneer towns into two categories, those that serviced travelers and those that supplied local residents. Baily further observed that the settlement distribution of a given region did not directly determine the location of supply-oriented pioneer towns. ${ }^{3}$ The actual location of pioneer towns appears to have been more a matter of circumstance than a natural outgrowth of a focused rural population center and its related needs. This was certainly the case with the founding of Hillsboro.

Hillsboro was founded at East Tualatin Plains, washington County, oregon. East Tualatin Plains was an

${ }^{2}$ Barbara Ruth Baily, Main Street. Northeastern Oregon. The Founding and Development of Small Towns, (Portland, Or.: oregon Historical society, 1982), 39.

${ }^{3}$ Baily, Main street, 41. 
isolated settlement community in the Tualatin valley in the 1840s. The early economic isolation of East Tualatin Plains was mitigated by its abundantly productive land. Farmers were eventually compelied to seek outlets for their surplus produce. The businessmen of Portland were eager to provide these outlets. Between 1845 and 1849 , the new settlement that was to become the city of Portland attempted to forge a commercial link with the Tualatin Valley hinterlands. The pioneer town of Hillsboro was eventually to become East Tualatin Plains' link between farm and market.

Robert Dykstra, in his work on the cattle frontier, provides an interpretive theme for examining how small frontier towns evolved. He calls this theme the urban impulse. The existence and force of the urban impulse is predicated on the purpose of the town. If a town's purpose is economic, and its economic organization is based on commerce rather than agriculture, then the urban impulse is stimulated, and the town grows. In such a town, the urban impulse creates a dichotomy between the Jeffersonian dream of isolated self-sufficiency and capitalist growth, a split between country and town."

Hillsboro never responded to the urban impulse. Its original purpose was to be the seat of local government and to serve the needs of the surrounding agricultural community. The frontier was longer-lived in the hinterlands

-Robert Dykstra, The Cattle Towns, 
of the Northern willamette Valley, due in large part to the limits of the transportation system. The relative isolation of the agricultural community of East Tualatin Plains from the willamette ports until the advent of rail service in 1871 isolated Hillsboro from commercial development for over twenty years. Those formative years determined the town's fate and set a tone which precluded substantive commercial development.

William G. Robbins, in his studies of Roseburg, oregon, has documented the evolution of a small town economy from agriculture to commerce. Roseburg had a history similar to Hillsboro in that it was platted as a county seat in 1854 and remained an agricultural service center until the arrival of the railroad in 1872.5 Robbins documents a slow transition from agriculture to commerce. Roseburg grew, but mostly in terms of farm-related occupations and businesses. It was not until the arrival of the railroad that the town became a true center of commerce. ${ }^{6}$

The railroad, the symbol of nineteenth century entrepreneurial capitalism, made the difference to some of the small towns of the oregon frontier, but not all. The

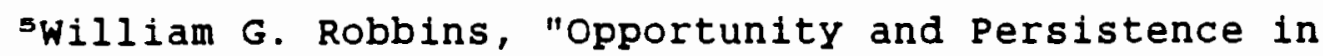
the Pacific Northwest: A Quantitative study of Early Roseburg, oregon," Pacific Historical Review, 34(1970), 283.

'William G. Robbins, "Social and Economic Change in Roseburg, Oregon, 1850-1885," Pacific Northwest Quarterly, $64(1973), 81-82$. 
nature of the settlement communities that gave birth to such towns as Hillsboro determined the response to the urban impulse. The East Tualatin Plains community was populated by settlers antipathetic to commerce. The urban impulse was thwarted in Hillsboro because the townsmen who settled there held a small town version of the same antipathy.

The rural frontier community that developed at East Tualatin Plains in large part defined the town of Hillsboro. The relationship between East Tualatin Plains' settlement and its historic landscape will be examined in the following chapters in order to understand that community. Hillsboro's early character depended not so much on who founded it as why it was founded, who populated it and the town's relationship to the surrounding community. 


\section{CHAPTER II}

\section{THE HISTORIC LANDSCAPE OF THE TUALATIN VALLEY}

At the end of the west, ringed round by outliers of America's last mountains, the coast Range, lies a sheltered plain of fertile soil. Mainly it is open land. Under its spectacular sunsets that gloss a thousand miles of open oceans, its grassy stretches gleam. In the month of May they glisten with the skyblue flowers of the wild hyacinth, the camas plant. It is a shining country.?

The above passage is by the foremost amateur historian of washington county. It was written as an introduction to the only comprehensive historical overview of the history of Washington county in existence. It is fitting that its author chose to introduce his subject as a historic landscape. An understanding of the geography of the Tualatin Plains is important to a discussion of the evolution of the frontier agricultural community that was established there between 1840 and 1870 .

The Tualatin Plains are located in the center of the Tualatin Valley, a branch of the Northern willamette valley. The Chehalem and Tualatin Mountains extend across its western lowlands to almost completely encircle the 200

"Robert L. Benson, "The Glittering Plain," Land of Tualaty, Vol.1 (Hillsboro, Or.: Washington County Historical society, 1976) 1 . 
square mile Tualatin Valley. The Plain consisted of some 50,000 acres of the finest farmland in the west. It was very level, varying only between 175 and 230 feet. ${ }^{10}$ The actual plain can be roughly defined as oval in shape, extending from the present day community of Banks in the northwest to the community of orenco to the east, with scattered sub-prairies to the southeast. In terms of the cadastral survey, the bulk of the Tualatin Plains can be found in Township 1 North, Range 2 West, Township 1 North, Range 3 West, Township 1 south, Range 2 west. For the sake of the discussion, Township 1 South, Range 3 west is also being included, in order to include all of the area around the future town of Hillsboro.

The valley, and its plains, are named for the Tualatin River which runs through it. The Tualatin River constitutes a boundary line delineating the Tualatin plains to the north and east of its path through the four townships. Its various tributaries, that is, the west and east forks of Dairy Creek, and Rock Creek, serve to further delineate the

'William A. Bowen, The Willamette Valley. Migration and settlement on the oregon Frontier. (Seattle, Wa.: University of Washington Press, 1978) 6 .

'Robert L. Benson, "Aloha's Donation Claims," Mss.220, washington County Museum, Washington County, Oregon.

10Benson, "The Glittering Plain", 1. 
Plains into smaller prairies. ${ }^{11}$

The water levels of the Tualatin River and its tributaries were similar to other waterways in the Northern willamette valley. They were lined with dense timber that could be one-half to three miles in width. The water levels were subject to dramatic seasonal flooding, creating marshes and small lakes. In between these belts of timber lining the streams, the valley floor was open and diversified, with large tracts of prairle and oak (or oak and fir) savanna alternating with groves or small forests of oak and fir.12 The open plains were a product of human settlement. As William Bowen has observed:

From their earliest days of exploration most travelers ascribed the prairies' existence to Indian burning. During the dry season each year, the natives purposely set large fires in the grass and woodlands. ${ }^{3}$

This was done to hundreds of square miles, for food management purposes.

Perhaps the best overall historic description of the

${ }^{1}$ Robert $w$. Keeler, "Observations and Predictive Hypotheses on Archaeological site Locations, washington County, oregon." Cultural Resources Management Program, survey report, 13 October, 1980. CRM collection, washington county Museum, washington County, oregon.

${ }^{2}$ Henry B. Zenk, "Contributions to Tualatin Ethnography: Subsistence and Ethnobiology." Master's Thesis, Portland state University, 1976.

13 Bowen, The willamette Valley, 60; see also Zenk, "Contributions to Tualatin Ethnography: Subsistence and Ethnobiology," 22-24, for detailed discussion and citation of early nineteenth century sources regarding Native American use of field burning. 
Tualatin Valley is one provided by John Work, an employee of the Hudson's Bay Company, in 1834:

On reaching the plains some oak of a middling size fringe the edges of the woods. There are also some ash and other trees. The country on getting out of the woods has a beautiful appearance. It is a continuation of plains which commence here and continue on to the southward, separated by narrow strips of timber, bounded to the east by the strip of woodland which occupy the banks of the willamet[sic]; and the westward by the woods which occupy the base of the Killymaux[Tillamook] Mountain[= Coast Range].

The soil is a rich blackish mould covered (but not with a close thick sward) with grass \& other plants, among which are considerable quantities of strawberry plants, now well furnished with fine fruit. Not a stone \& scarcely a shrub to interrupt the progress of the plough which might be employed in many fields with little more difficulty than in a stubble field.

The open country here is of an irregular form, as points of woods jut out into the plains from both sides. . . The open ground here may be about 3 or 4 miles wide from E.S.E. to W.N.W...

John S. Griffin, a settler of 1841 , has left a lyrical description of his swn land claim on East Tualatin Plains:

The clain was entirely destitute of timber, except a fow ash troes which arew $a$ long the margin of the swal?s. The plain was bealutifil and was divided from the plains adjoinino by Iiving streams of water flowing from the mountains. the banks of which streams were skirted with fir and white cedar timber. The surface of this plain was gently undulating, barely sufficient for drainage. The land on both sides of these swales being clear prairie, the rows of green ash in summer gave the plain a beautiful appearance." $1 \mathrm{~s}$

Another period source provides a full inventory of the

1 aenk, "Contributions to Tualatin Ethnography: subsistence and Ethnobiology." 28-29.

1sHarvey E. Tobie, No Man Like Joe (Portland, or.: Binford and Mort, 1949) 96 . 
kinds of trees and other plants that composed the many woods that broke up the prairies. They included fir, pine, oak, cedar, hemlock, white oak, alder, ash, cottonwood, dogwood, cherry, maple and hazel. In addition, berries of all kinds grew wild in the woods. ${ }^{20}$

It is not difficult to see how both settler and scholar alike could come to the conclusion that more than any other aspect of the physical landscape, the prairies determined the location of settlement in the center of the Tualatin Valley. ${ }^{17}$ (see figure 1: prairie and swamp lands)

The landscape of the Tualatin Plains was therefore not just a natural tableau awaiting the Euro-American settler. It was a historic landscape that had been shaped in part by centuries of human use. Scholarship has tended to minimize the overall import of the Native American presence in the Tualatin Valley, due to the demise of these people through epidemics prior to substantial Euro-American settlement. ${ }^{10}$ However, it would be inappropriate to gloss over their prehistoric and historic presence. The Native American population of the Tualatin valley did have a considerable presence during the early settlement years, from 1840 to 1855. Their legacy to the Euro-American settlers included a

${ }^{16}$ Kenneth L. Holmes, Covered wagon Women. Diaries and Letters from the western Trails, 1840-1890. Ed. K. Holmes. 4 Vols. (Glendale, Cal.: Arthur H. Clark, Co.,1983) 108.

17 Bowen, The willamette Valley, 61 .

19Bowen, The willamette Valley, 59. 
11

TIN.RSW

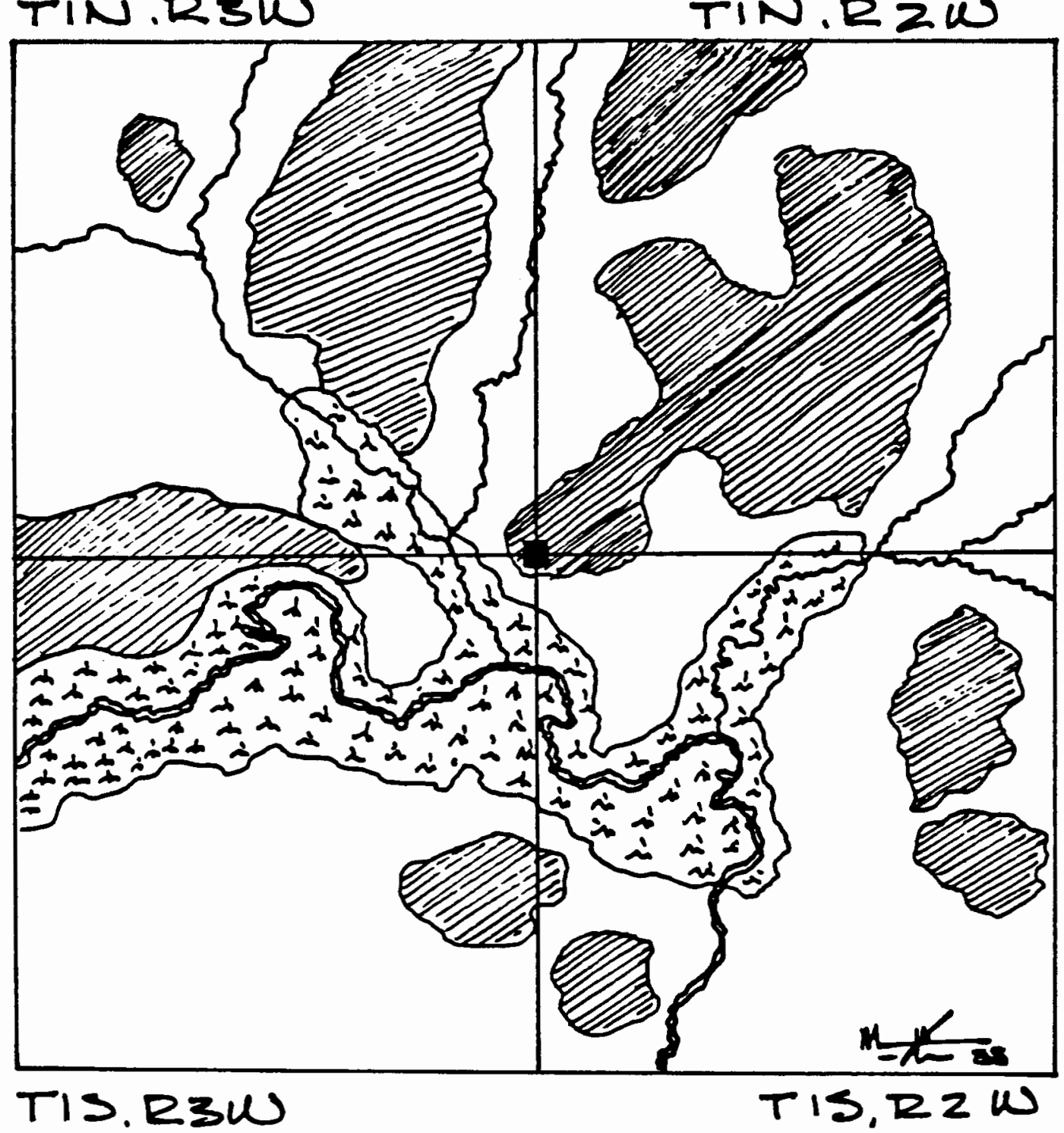

Praíí

( ) SuAmp/tatromLand

- hilgsoreo

Figure 1. East Tualatin Plains Prairie and Swamplands. 
network of trails, open prairies and a sense of habitat that facilitated their settlement.

The Atfalati presence in the Tualatin Valley was a long one, at least five to eight thousand years.19 They were a dialectic "band" of a Kalapooian linguistic stock. The Kalapooian dialects were spoken throughout a large portion of the western side of the Northern willamette valley. The exact meaning of their name is not known. ${ }^{20}$ Much folklore exists as to various meanings but none of it has been substantiated by anthropologists. The Atfalati were preliterate, and could only communicate orally with the EuroAmerican settlers. The result was a range of pronunciations for the Atfalati's name as it was filtered through English and perhaps other languages. Many spellings of this phonetically developed name appear in the early records: Falatine, Twalatin, Twalati, Faladin, Twalitine, Tuality, Tualatin. 21

The early Euro-American settlers, perhaps with the aid

1 'Harold Mackey, The Kalapuyans. A Sourcebook on the Indians of the Willamette Valley. (Salem, or.: Mission Mill Press, 1974) 1. Also, Native American artifacts contained in the collection of the Washington county Museum have been evaluated by archaeologists as being between five to eight thousand years old.

zomackey, The Kalapuyans. 8-9.

${ }^{2}$ one anthropologist, Henry Zenk, Ph.D., is of the opinion that the closest approximation in correct pronunciation of Atfalati is T-fal-iti, the "A" being silent, the "T" being pronounced softly, with the accent being placed on the last two syllables. If that is so, then the many spellings of the name are understandable. 
of chinook jargon, did manage to associate the name of the Atfalati with the river in the valley. Thus the river, the valley and the central plains all bore the name of the original Native American inhabitants. 22

A time-proven knowledge and use of the landscape of the Tualatin Valley was well established when Euro-American settlement began. The valley was not a dense, virgin forest but a well-used human habitat of open prairies, laced with internal trails and linked to the surrounding Northern willamette valley by trade routes. All the reconnaissance and some of the development necessary for efficient settlement and land use had been accomplished long before Euro-American settlement.

While the Atfalati had a presence in the Tualatin valley during the early settlement period, it was but a shadow of the culture as it had existed in earlier centuries. The entire Native American population in the lower columbia region suffered horrendous losses from epidemics. A major smallpox epidemic raced through the area in 1782-83 brought by contact with Euro-American maritime exploration. Venereal disease was also a problem, from the same source. By far the most devastating was the malaria

$2{ }^{2}$ Chinook jargon was patois devised by the chinook people for trade purposes that was used as a common language by Native Americans and Euro-Americans alike. It evolved during the late pre-historic period in the Pacific Northwest and flourished during the historic period of Euro-American contact, picking up borrowings from English, spanish and French. 
epidemic of 1830-33 that was borne west from the Mississippi valley via Native American contacts.23 In 1833 , an official of the Hudson's Bay company estimated that

since the year 1829 , probably $7 / 8$ ths if not, as Dr. Mcloughlin believes, 9/10ths of the native population in the willamette valley have been swept away by disease... whole and large villages have disappeared. 24

By the time the first few Euro-American settlers began arriving in 1838-39 in the Tualatin Valley, the Atfalati were significantly reduced in number. Not so much as to go unnoticed, however.

The natives were generally helpful to the newly arrived immigrant. In exchange for beads and utensils and other coveted articles, they brought fish, wild meat and skins. 25

Joseph Gale, an early (1838) settler in the Tualatin Valley, encountered many Native Americans in his area, and reported that he had regular contact with them. He spoke of the Atfalati as a sensitive people, poetic about their environment. 20 Another early settler, A.T. Smith, mentioned seeing a large group of Indians on the Plain in $1841 .{ }^{2}$

The settlement community's perception of the Atfalati

${ }^{23}$ Harold Mackey, The Kalapuyans. 20.

24 Stephen Dow Bechham, The Indians of Western Oregon. This Land Was Theirs. (Coos Bay, Or.: Argo Books, 1977) 109.

2 Tobie, No Man Like Joe, 112.

25Mackey, The Kalapuyans, 18-19.

27Alvin Thompson Smith, Diary, 1840-1853. A.T. Smith papers, Mss.8, oregon Historical Society, Portland, oregon. 35 . 
changed as the competition for land increased during the latter part of the 1840s. Frontiersmen Gale's appreciation for the Native Americans was supplanted by an official perspective that was far less tolerant. In a report dated 22 october 1849, Governor Joseph Lane stated the view of the Territorial Government.

The Tualatene Indians occupy that portion of the country west of the willamette River. They are a degraded, worthless and indolent people. They are poorly armed and entirely inoffensive. They live on roots, fish and berries. They number about $60 .{ }^{28}$

By 1851 treaty negotiations were underway with the Atfalati, the intent being to remove them to a reservation in the Tualatin Valiey centered on their winter village concentration around Lake wapato. (see figure 2) The Atfalati were willing to co-exist with the whites on the basis of mostiy cordial relations. 29 The proposec treaties of 1851 were rejected by the Federal government. By the time a new treaty was negotiated in 1855 , settrement in the Tualatin Valley precluded the viability of the proposed reservation. The remaining Atfalati, some sixty in number, were removed to the Grande Ronde reservation in Yamhill county. The Atfalati continued to pass through the valley in small groups for years after removal, but were never much more than a curiosity or occasional nuisance to the

\footnotetext{
$2{ }^{8}$ Mackey, The Kalapuyans, 84 .

29Mackey, The Kalapuyans, 105. See Benson map on page
} 16 re location of reservation. 


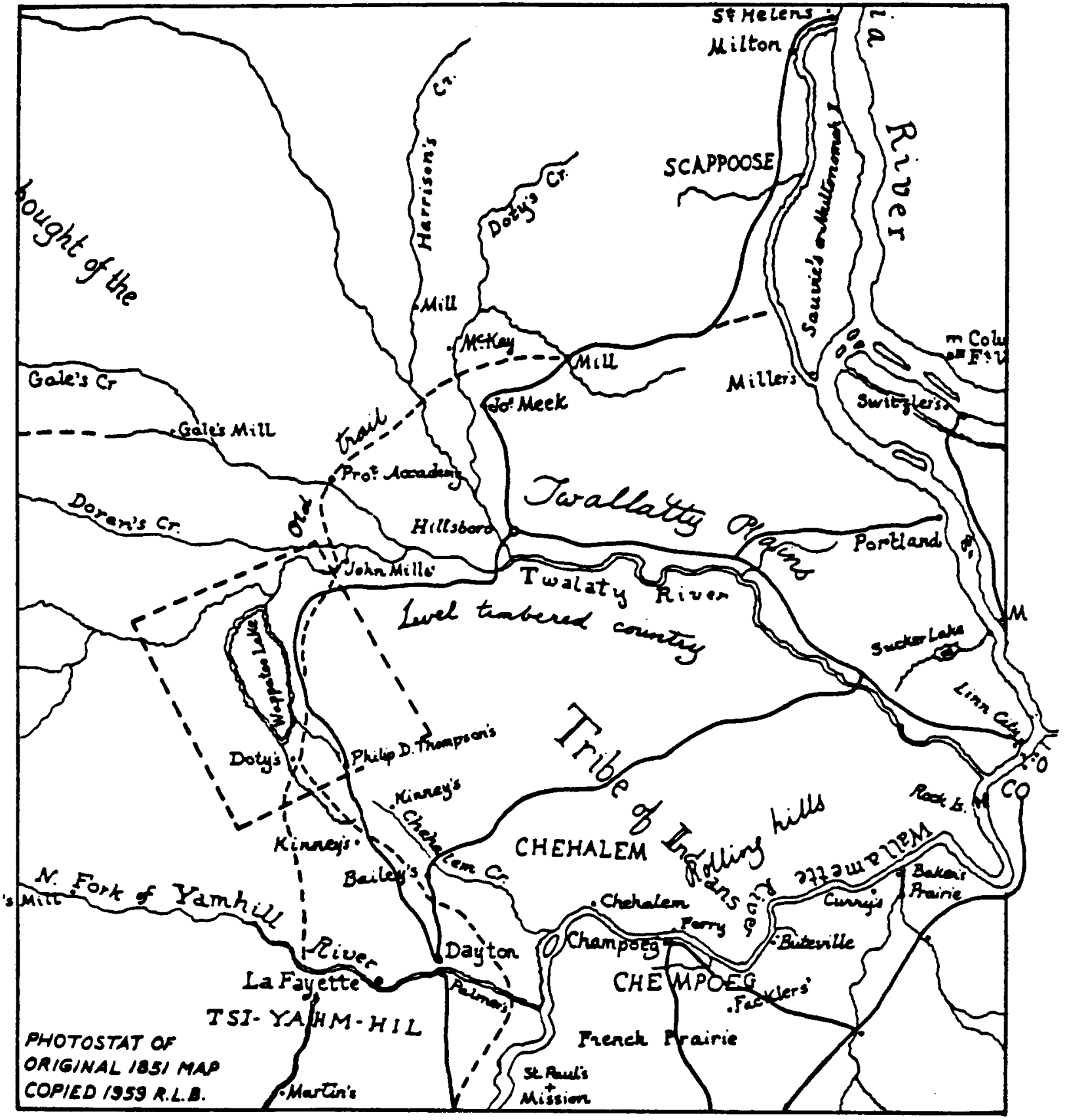

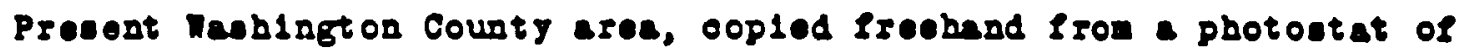
Yap 195, Tubo 458, ouppl lod by Nat lonal Areblres, Neablagton, D. C. 800 photontat at WeshIngton County unoum, H1lloboro. OnItt od abore aro (1) auob of a diagonal pbrace terrltory bougbt of tbe twallaty Band of the Callapoora Tribe of Iadlana; (2) Reservat 1 or of the Tralaty Band of the Callapooga Tribe," In the onolooure eurroundiag Deppat oo Lare; (3) blll obadinge.

Figure 2. Willamette Valley, 1851. 
settlement community. 30

soInventory of the county Archives of Oregon, No.34. washington County, oregon. (Portland, or.: oregon Historic Records survey, Works Progress Administration, 1940) 6-7. 
CHAPTER III

\section{THE SETTLEMENT OF EAST TUALATIN PLAINS}

The history of Euro-American settlement in the Tualatin Valley as a whole is beyond the scope of this work. The valley includes several settlement foci, each with its own unique history. Having introduced the historic landscape of the Tualatin plains, the balance of the discussion will be focused on that part of the Tualatin Plains known between 1840 and 1850 as East Tualatin Plains. It was there that the pioneer town of Hillsboro was eventually founded. The East Tualatin Plains settlement community included several distinct groups of immigrants. Tracing who settled East Tualatin Plains chronologically provides a framework for understanding the agricultural community that surround the future town of Hillsboro. The nature of that community greatly influenced the evolution of the town.

The Plains were early divided into two geographic components by virtue of settlement clustering: West Tualatin Plains and East Tualatin Plains. These distinctions were reflected in postal addresses, diary references and the general usage of the day.31 The two settlement clusters

31 John Smith Griffin, Record Book for the First Congregational Church of the Tualatin Plains, Griffin Papers, Mss. 1075, Oregon Historical Society, Portland, 
were based in part on religion. Among the earliest settlers were several independent American Congregational misstonaries and their famllies. One group centered on Alvin Thompson Smith's clalm on the western edge of the plain, while the other centered on J.S. Griffin's claim on the eastern edge. The full import of the role of religion in such settlement clusters is discussed below. 32

The focus of initial settlement on edges of the Plains is not coincidental but reflects a clustering tendency exhibited on earlier frontiers.33 The tendency is based on common sense. Immediate access to fuel and building materials in proximity to open agricultural land made the wooded fringes of open grassland the place to settle rather than the open prairie itself. Access to water for drinking, cooking, washing and transport was also a factor, and the wooded areas of the Tualatin Plains coincided with fresh water.

By 1845 the agreed upon dividing line between the two

Oregon. See entry for 17 March, 1845.

32 The independent congregational missionaries did not operate with the support of the missionary bureaucracy of the Congregational church. They believed in a personal missionary responsibility, and pursued it with considerable zeal. See steve Richardson, "John Smith Griffin, Independent Missionary to the Indians and Tualatin plains Pioneer." Master's Thesis, University of oregon, 1986.

${ }^{33}$ see John Mack Faragher, Sugar Creek. Life on the Illinois Prairie. (New Haven, Conn.: Yale University Press, 1986) 67, for a discussion of similar settlement patterns on the IIlinois frontier, 1830-1850. 
settlement communities on the Tualatin Plains was the west bank of Dairy Creek. 34 The agreement was based on common sense. One half of the tiny congregation that met at Griffin's claim on East Tualatin Plain had to travel the six miles from west Tualatin Plain at least once a week, over dirt tracks that were mostly mud six to eights months a year. It was obviously easier to meet religiously as well as socially closer to home.35

Travel for purposes of business and politics was another matter, as many of those requirements had to be addressed outside the Tualatin Plains. Thus, the rigors of travel coupled with the practical convenience of the frontier combined to produce an orbit for settlement communities on the Tualatin Plains of about three to four miles. This norm is reflected in the development of settlement clusters with the East Tualatin Plains, and the rise of Hillsboro after 1850. Recent scholarship on this clustering effort substantiates the conclusion. 36

There are no hard and fast boundaries for East Tualatin Plains as a study area. While the general boundaries of

$$
\begin{aligned}
& \text { 34Griffin, Diary, } 17 \text { March, } 1845 . \\
& \text { 3ssteve Richardson, "John Smith Griffin, Independent }
\end{aligned}
$$
Missionary to the Indians and Tualatin Plains Pioneer," Master's Thesis, University of Oregon, 1986.

${ }^{35}$ Paul F. Bourke and Donald A. Debats, "The structures of Political Involvement in the Nineteenth Century: A Frontier Case." January, 1987. Mss. collection, Washington county Museum, washington County, oregon. 
East Tualatin Plains are not neatly square, the four townships Iisted in Chapter 1 include most if not all of the Tualatin Plains, and allow for a cartographic presentation of the study area. (see figure 1)

The Tualatin Plains was not the first part of the Northern willamette Valley to be settled. It was somewhat off the path of the Hudson's Bay Company's routes along the Willamette to its stations upriver, and also somewhat out of the orbit of the Methodist mission to the south. The valley was not completely unknown to the Company. The Hudson's Bay Company did pasture cattle in the Tualatin Valley in the 1830s. Presumably there were herdsmen's camps during the summer grazing months, located along the western slope of the Tualatin Mountains at the base of the trails made by the Native Americans. These trails would have been used to herd cattle into the valley from Fort Vancouver, via sauvie Island. 37

As a known but unsettled area, the Tualatin plains was ideally situated, the right place at the right time, to become home to a rather disparate lot of early settlers. The overall settlement population of the oregon country was highly homogeneous. However, the settlement of the Tualatin Plains indicates that while the frontier population may have

37 Robert $w$. Keeler, "Introduction and Guide to An Existing Data Inventory of Archaeological Resources in Washington County, oregon," Cultural Resource Management Program, survey report, 10 october, 1980. CRM collection, Washington County Museum, Washington County, oregon. 
been homogeneous by 1850 , it was not always so at the outset in specific areas. The initial diversity of East Tualatin plains' settlement played a distinctive role in the evolution of the East Tualatin Plains community.

Four distinct groups settled the Tualatin Plains between 1840 and 1850: retiring American independent fur trappers, independent American evangelical protestant missionaries, disgruntled Hudson's Bay Company employees from the failed Fort Nisqually venture -- commonly referred to as the Red River Canadians --, and immigrant farmers from the ohio and Mississippi river valleys.

The American fur trappers entering the willamette Valley were few in numbers. They were the remains of the independent American brigades that had worked the Rockies for the previous twenty years until changes in fashion and the depletion of the furs combined to drive them out. William Bowen has described them as a rough lot. "They were free men from the western states, potentially violent, uncouth vagabonds."30 Even by the standards of the day such an assessment is probably reasonable. One author described them as "poor, prodigal, not always industrious."ss

The most famous of this group, Joseph L. Meek, confessed a lack of focus when he settled his claim on the

3 Bowen, The willamette Valley, 12.

39 Frances Fuller Victor, The River of the west, (Hartford, Conn.: Columbian Book Co., 1870) 295. 
East Tualatin Plains in $1841 .^{\circ}$ As settlers, however, they were as good as any other. They brought their own special skills of leadership born of long independence and considerable self-confidence. During the early days of settlement, Meek and others were instrumental in mitigating conflicts with the Klicitat Indians who were raiding through the Tualatin valley. The mountain men used their experience with Native American diplomacy gained during the fur trade to good effect. ${ }^{4}$

Rough they may have been, but they had their own role to play apart from being farmers. Many of these men also had Native American wives, something that set them apart from other settlement groups, and which would become a social issue later in the development of the community.

The independent protestant missionaries were opponents of the Amertcan Board of Commissioners for Foreign Missions (Presbyterian and Congregational) as well as the Methodist Mission Board. They lacked both the financial support and the moral respectability of the establishment missionaries. ${ }^{2}$ The various members of this group who settled on the Tualatin Plains did so out of desperation. They had no place else to go. Their missionary efforts had failed elsewhere in the oregon country. Their leader, John

\footnotetext{
-Tobie, No Man Like Joe, 98.

-1Tobie, No Man Like Joe, 193.

"2R1chardson, "John Smith Griffin", 1.
} 
Smith Griffin, dreamed of a new American society built on Christian ideals. They hoped to find enough Indian souls to serve as a foundation of that society. The Atfalati's numbers and interest levels were insufficient to effect such a plan. The Griffins, and missionaries who arrived later, turned to building their dream society amongst themselves and the Americans who followed them.3 This group of settlers exerted a moral and social influence on the Tualatin plains well beyond their modest numbers.

The Red River Canadians were another group of early settlers who came to the Tualatin Plains after having falled elsewhere on the frontier. This group was composed of British subjects as well as Anglo-Metis from the Red River settlement of the Hudson's Bay Company in what is now Manitoba, Canada. The Anglo-Metis are a less well know version of the French-Metis, men and women of mixed French Canadian and Native American origins. The French Metis had long been a source of labor for the Hudson's Bay Company throughout their empire. The Anglo-Metis tended to be of mixed Scots and Native American origins. The mixed blood of the Anglo-Metis settlers, such as Charles and Letitia McKay, would later become a social issue on the East Tualatin Plains, as would the Native American wives of the retired fur trappers.

The Hudson's Bay Company had previously recruited the

"Richardson, "John Smith Griffin", 32-33. 
Red River Canadians for the Puget Sound Agricultural Company venture at Fort Nisqualiy. This was a subsidiary effort aimed at an agricultural colonization of the territory north of the Columbia. The colony was established in the fall of 1841. Free land to the south of the colony, coupled with poor pay and poor weather conditions, combined in the 1840 s to draw the disgruntled settlers to the Tualatin plains and points south.*

The numbers involved in the Red River Canadian immigration were significant. One hundred and sixteen people, composing twenty-one families settled at Nisqually. By the fall of 1843 all of these people had settled in the willamette valley.4 There is some question as to dates of arrival. The reminiscences of William G. Flett, son of a Red River Canadian David Flett, who settled on the East Tualatin plains present a different accounting. William G. Flett was born in 1842 on the northern fringe of East Tualatin plains. In 1892, he remembered eighty-four people in the Red River immigration who had come south in 1842 . However, it is unclear from his comments as to how many initially settled on the Tualatin plains and remained.40

-4Bowen, The willamette Valley, 11.

4 John S. Galbraith, The Hudson's Bay Company As An Imperial Factor, 1821-1869, (Berkeley, Calif.: University of California Press, 1957), 212.

${ }^{40}$ William G. Flett, Reminiscences, Mss. 335, Oregon Historical Society, Portland, Oregon. 
Another account, by an unknown member of the Thomas Tounge family, places at least one of the Red River settlers, Thomas Otchins, on the East Tualatin Plains by September of 1841.7 Given the eventual number of land claims on the East Tualatin Plains taken out by Red River Canadians (6), it would appear that many moved on between 1842 and 1851-2, when the General Land office survey maps showing Donation Land claims were drawn. It may be that these families drifted south as circumstances permitted and arrived on the Plains between 1841 and 1843 .

The Red River Canadians brought an early British presence to the Tualatin Plains, but not as official representatives of the crown. The presence perhaps served to leaven the American dominance on the Plain and provide a degree of cultural diversity.

The final category of settlers on the East Tualatin Plains consisted of American overland immigrants. The initial representatives of this group arrived in 1841 . They were Isaiah Kelsey, David Hill and Richard "Irish Dick" williams. ${ }^{4}$ The first Americans came alone. They were,

4 Tounge family history, Mss., washington county Museum, washington county, oregon. The Tounge family was related to the otchins family, both having originated in England.

4 Tobie, No Man Like Joe, 100. These arrivals are also confirmed by a letter from a correspondent in the 15 November, 1846 edition of the oregon spectator, cited above. 
according to Charles Carey, "American stragglers."4 Elijah White's wagon train brought about 100 immigrants to the willamette Valley in 1842 , but most settled around oregon city. A few may have found their way to the Tualatin Plains. It was not unt1l the Great Migration of 1843 , numbering about 800 immigrants, that the American population on the East Tualatin Plains began to grow. 50

An American naval officer commented briefly in an 1846 report on his impressions of the American overland immigrants. "They come generally from the poorer classes of the western states, ... with the design of improving their fortunes."si A later scholar would characterize this group a bit more critically.

In a few words then, the oregon settlers as a class, were plain, respectable, common people, in moderate circumstances, many of whom were fairly well educated but few of whom could be called cultivated. They were independent, resolute, aggressive, national and with a gift for politics. They were scrupulously honest, fairly progressive, not usually given to overwork. 52

Another contemporary account put it this way.

The fact is, this country - and it will surprise you little if you are not aware of it - is settled by a very steady people, and it was settled by families; a very moral people as a rule. ${ }^{33}$

- Charles H. Carey, A General History of oregon, 2 vols. (Portland, ore.: Metropolitan Press, 1935), 369.

soBowen, The willamette valley, 12 .

sxCarey, A General History of oregon, 405.

52 W.C. Woodward, "The Rise and Early History of Political Parties," Oregon Historical Quarterly 11(1910), 330 . 
The general motivations for the westward movement have been thoroughly discussed by recent scholars, although not all are in agreement on why people went to oregon. According to John Mack Faragher, the immigration was based on economic reasons. Most immigrants wanted new land.s There were several factors, including economic ones, behind the westward migration: the Panic of 1837 , rising land prices, reaction to slavery and its impact on free labor and the market economy, religious zeal, manifest destiny and a general spirit of adventure.ss The most recent scholarship also suggests that matters of health may have been amongst the prime motivations.so A recent study of an Illinois frontier community, sugar creek, confirms the unhealthy nature of the Mississippi Valley, especially Illinois, which one old settler referred to as a "graveyard". 57 Many overland immigrants to oregon came from

su John Mack Faragher, Men and Women on the oregon Trail, (New Haven, Conn.: Yale University Press, 1979), 13.

${ }^{55}$ Woodward, "The Rise and Early History of Political Parties," 324-326. See also Dorothy o. Johansen, "The Land Base of Oregon's Economy," Genealogical Materials in the Oregon Donation Land Claims, Vol.2 (Portland, or.: Genealogical Forum of Portland, 1959), 4; Arthur L. Throckmorton, Oregon Argonauts. Merchant Adventurers on the oregon Frontiers, (Portland, Or.: Oregon Historical society, 1961), 31; Dorothy O. Johansen, "A Working Hypothesis For the study of Migrations," Pacific Historical Review, 31 (Feb. $1967), 1-12$.

sobowen, The willamette Valley, 18 .

s7John Mack Faragher, Sugar creek. Life on the Illinois Prairie (New Haven, Conn.: Yale University Press, 1979), 8990. 
such communities as sugar creek in the 1840s.50

one example of the concern for health matters can be found amongst the settlers' letters. Rachel Fisher Milis commented upon the better health climate on the Tualatin Plains in an 1848 letter.so Another, earlier settler, Peter Burnett, stated the following purposes for going to oregon.

1. to assist in the building of a great American community of the Pacific Coast. 2. to restore the health of Mrs. Burnett. 3. to be able to pay my debts.50

Burnett wrote this in later years. As a politician he can perhaps be forgiven in placing Manifest Destiny before his wife's health, or his debts.

Robert Newell, one of the American fur trappers who initially settled on the Tualatin Plains, wrote from there in 1841 that "this country is not so good as supposed, as the climate is not so healthy. I have had some sickness and so has my family."61 It may be that the American immigrants came west in search of healthier climes, but the Tualatin plains during the rainy season may have appeared to some to be less than they had hoped for.

In terms of the overall immigration to oregon between

58 M.L. Wardell, "Oregon Immigration Prior to $1846, "$ oregon Historical Quarterly 27(1926), 57.

59 Holmes, Covered Wagon Women, 105

oopeter H. Burnett, "Recollections and opinions of an old Pioneer," oregon Historical Quarterly, 5(1904), 183.

s'Tobie, No Man Like Joe, 101. 
1840 and 1850 , the western border states of Arkansas, Iowa and Missouri formed the single most important region, generating almost $23 \%$ of the total population. Missour 1 was especially prominent. Illinols, Ohio and Indiana provided another $21 \%$ to the total. of the south central states, Kentucky ranked fourth, and Tennessee tenth, for a total of $9 \%$ of the 1850 population. While two thirds of the U.S. population resided in the Atlantic and Gulf states, only 19\% of the 1850 oregon population came from these regions. New England and foreign born, mostly Anglo-saxons, each represented about $4 \% .62$

W.C. Woodward established that most of the overland immigrants came west in a series of moves, usualiy in three stages. For example, New York - IIlinois - Iowa, and then on to oregon. ${ }^{3}$ It appears that the earlier immigrants to the willamette valley tended to have made fewer previous moves than the later ones.

An analysis of the 94 households that established land claims on the East Tualatin Plains by 1851 seems to bears this out. These settlers averaged two moves per household, although many had three. The reason for the sightly fewer

$6{ }^{2}$ Bowen, The willamette Valley, 24.

" Woodward,"The Rise and Early History of Political Parties," 328. See also Bourke and Debats, "The structures of Political Involvement in the Nineteenth Century: A Erontier Case," 14 .

-Bourke and Debats, "The structures of Political Involvement in the Nineteenth Century: A Frontier Case," 14. 
moves for the East Tualatin Plains settlers may lie in their origins. A breakdown of the total adult population of the East Tualatin Plains as of 1850 reveals some interesting anomalies compared to the overall population of the territory. (See Table I, page 32.)

The foreign born population was three times the territorial average, and was almost exclusively English or Canadian. The New England population was double that of the territorial average. Only the middle Atlantic and the south had representation on the East Tualatin Plains in rough proportion to the territorial average. Of the individual states, Kentucky and ohio had significantly higher representatives than Missouri, which is often credited as home to many of the overland immigrants.

There appears to have been a great deal more mobility amongst the settlers who arrived between 1840 - 1845 than those who arrived between 1845-50. Of that population, many came and went without establishing permanent claims, for example, the Red River Canadians already discussed. Some of the American fur trappers and other early Americans moved on, such as Robert Newell, Peter Burnett, George Mccarver.os Others, such as Flett. died.

There are no complete census figures for oregon as a whole until the 1845 census. Unfortunately, that census

"Benson, "The Glittering Plain", 
TABLE I

EAST TUALATIN PLAINS POPULATION IN 1850

\section{PERCENTAGES BY REGION}

1. Ohio and Mississippi River valley:

147 (53\%)

2. Middle Atlantic:

$36 \quad(13.5 \%)$

3. South:

$31(11 \%)$

4. Foreign Born:

$30 \quad(11 \%)$

5. New England:

$22(8 \%)$

STATE ORIGINS BY NUMBER RANKED BY FREQUENCY

1. Kentucky:

2. Ohio:

3. foreign:

4. Missouri:

5. New York:

6. Virginia:

7. Tennessee:

8. Pennsylvania:
$47 \quad(16 \%)$

37 (12.5\%)

$30 \quad(10 \%)$

24 (08\%)

19 (06\%)

15 (05\%)

13 (04\%)

$12(04 \%)$

NOTE: Population of East Tualatin Plains in 1850 was 295. only 266 are attributable to a birthplace. Census tracts for the 1850 census do not exist for the area known as East Tualatin plains. The population for that locale in 1850 was arrived at by correlating information abstracted from the Donation Land Claim applications with the 1850 census. The population analyzed only includes those settlers with established claims, that is, the landed population. 
does not 1 ist census districts, and thus we only have the raw figures for Tualaty District.* For this reason we have no way of knowing how many of the people listed in the 1845 Provisional Government census were actually residing on the East Tualatin Plains in that year, other than to match the 1850 Federal census data and information from the Donation Land claim abstracts with the 1845 census. Out of such a match we can place 23 households on established claims on the East Tualatin Plains, with a rough population estimate of approximately 130 people. One hundred and thirty people constitute eighteen percent of the Tualaty District census of 775 people. We do not know how many people beyond the 130 known settlers may also have been there. It is an important question, for it would indicate the level of transients in the community during the early years of settlement. We do know that East Tualatin Plains had approximately 396 settlers, or twenty percent of the 2,000 people in washington County in 1850. Thus settlement levels remained fairly consistent between 1845 and 1850 .

The bulk of the overland immigrants were overwhelmingly farming families, especially those from the western states. Amongst these 908 of the adult males were farmers. Six out

-omalaty District, later Tualaty county (1846), still later washington County (1849), was one of four administrative districts estabilshed by the Provisional Government in 1843. Tualaty District covered significantly more territory than washington County did in 1849, so the population figures for this district are misleading vis a vis the Tualatin Plains. 
of ten household heads were farmers.67 Therefore $30 \%$ of the adult males were single farmers, and $10 \%$ were tradesmen and laborers. Tradesmen were probably not highly represented in the first few years of settlement on the East Tualatin Plains, as the community could not support them. Tradesmen could command $\$ 5.00$ a day vs. $\$ 1.00$ a day for unskilled labor during this period.68

The earliest of the East Tualatin Flains settlers were economically self-sufficient people such as the American fur trappers. They had only limited reed of tracesmen during this early phase, as they could and did tend to most of their needs themselves. We could assume that the laboring population of early East Tualatin Plains to be somewhere in the range of $13+$ adult males, that is, $10 \%$ of the approximately 130 known residents in 1845 . However, a close look at the 1845 censlis records reveals 34 adult males lover 21) on the East Tualatin. Plains who were not heads of households.

Even allowing that some of these mer were the adult sons of the settiers, the number suggest a higher proportion of non-head-of-household adult males than one might expect or such a frontier. Forty percent of the male populatior were head-of-household farmers, while $60 \%$ were not. We do

- Faragher, Men and women on the oregon Trail, 16.

6o James Henry Gilbert, Trade and Currency in Early oregon, (New York: AMS Fress, Inc., 1967), 72 . 
not know who in that $60 \%$ were single farmers without land claims vs. laborers.

It is possible that most were sirgle non-landed farmers. We know from the 1850 census that there were 54 non-lanced adult maies on the East Tualatin Plains who were listed as laborers, or who had no occupation nor family association and, therefore, might be assumed to be laborers. That number constitutes $18 \%$ of the population of East Tualatin Plains in 1850. We also know, by comparing the names of these men with the 1845 census, that they ali came to East Tualatin Plains after 1845. Thus, it would appear that the need for such labor grew in proportion to the expansion of population. If that is so, then the smailer settlement population of East Tualatin Plain between 1840 and 1845 would have had less laborers, say $10 \%$ ( 13 plus) mentioned above. That would have left approximately 20 single young men at East. Tualatin Plains in 1845 who were probably farmers, but who elected to move on to another part of the county or territory prior to marrying and staking out a claim.

Such as assumption would make sense given what we know of the nature of the overland immigrants. The immigration that cocurred in the 1840 s was primarily carried out by families."s The bulk of that immigration came after 1843, and on the East Tualatin Plains, after 1845. Therefore, if 
most of the family immigration occurred after 1845, then a lack of persistence among a signiflcant proportion of the earlier population of East Tualatin Plains is understandable.

It has also been suggested that the age of settlers was an important factor in forming a distinct community identity, vs, transferring an older community from elsewhere. ${ }^{70}$ Analysis of the census shows that the mean age of the fanilies who settled on East Tualatin Plains in 1850 was 38 for husbands, and 34 for wives. The average number of children in these families was three. By assuming that a proportion, approximately 25\%, of these families were on the plain in 1845, then the mean age may have been ca. 33 for the husbands and ca. 29 for the wives.

It is possible that the establishment of the East Tualatin plains community did not take on serious proportions until there were a sufficient number of young families in place to give it substance. Such would also indicate a higher degree of transiency on the East Tualatin Plains between 1840 and 1850 than in later years. This transiency appears not to have been based on a lack of opportunity, as there was a great deal of land avallable between 1840 and 1847. Rather, it appears that there was not a sufficiently established community to either require

Topaul F. Bourke and Donald A. Debats, "The structures of Political Involvement in the Nineteenth Century: $A$ Frontier Case," 10-11. 
the labor of, nor offer soctal opportunities to single young men.

Such a conclusion is supported by Faragher's recent study of Sugar Creek, Illinots. Faragher identified two groups co-existing with each other. One was highly mobile, in that it farmed for a short while and then moved on. The other constituted a core of permanent landed families who supplied the continulty of community institutions. ${ }^{71}$ Faragher's findings suggest that the formation of the East Tualatin Plains community was perhaps as much a function of the settlement of a certain kind of immigrant rather than the mere numerical accumulation of population. Dorothy 0 . Johansen agrees with this point. She suggests that economic and environmental factors are less important than psychological factors, and that the differentiating factors of pioneer communities were rooted in the nature of the early population. A community's character, so formed, was then perpetuated by a continuing process of selective migration. 72

The nature of that immigrant has been defined above in terms of the sheer numbers involved. They were, by 1850, predominantly from the western states, especially the border states. They were predominantly farming families, composed

71 Faragher, Sugar Creek, 45.

72 Dorothy 0 . Johansen, "A Working Hypothesis for the study of Migrations," 36(Feb.,1967) 5 . 
of mature adults with an average of 3 children. Thus we have a profile of the bulk of East Tualatin Plains population by 1850 . What that profile belles, however, are the anomalies of the population, both in terms of its relationship to the entire northern willamette valley and the actual chronology of the settlement patterns of the Tualatin Plains between 1839 and 1850. The anomalles vis a vis the overall settlement of the willamette valley primarily relate to origins. While the western and border states composed the single largest block of the population of East Tualatin Plains, other groups are found there in surprising numbers. These anomalous settlement patterns had a significant impact on the early society of East Tualatin plains. For example, the greater number of New England and foreign born settlers arrived early, between 1839-1843. Given that these New Englanders consisted primarily of protestant missionaries, and, further, that the foreign population was composed of men and women traditionaliy outside the pale of New England society, it is quite likely that the seizure of the social and moral high ground on the East Tualatin Plains as a whole by the New Englanders was greatly facilitated by the "outsider" status of many of the forelgn-born and American mountain men. Even the arrival of American "stragglers" between 1841-43 did little to counter that dominance, as with the exception of farming there was little in common culturally. The 
agricultural nature of East Tualatin Plalns was indeed 1 ts major bond. It is necessary to look beyond that common bond to distinguish the patterns of development of East Tualatin Plains. 
CHAPTER IV

\section{SETTLEMENT CLUSTERING AND THE DEVELOPMENT OF EAST TUALATIN PLAINS NEIGHBORHOODS}

The settlement patterns between 1840 and 1850 reveal how the geographic distribution of the four groups related to the development of the East Tualatin Plains community. Examining settlement patterns is an approach that recent scholars have applied to the Northern willamette Valley as a whole, and washington county in particular. It remains to pursue the approach in terms of one specific community. 3

By 1850 the community of East Tualatin Plains was not a small one. It comprised more than three full townships, approximately 70,000 acres. East Tualatin Plains was in fact composed of several neighborhoods, which were based on the clustering patterns of its settlement. Bowen asserts that these neighborhoods are very important to an understanding of frontier communities such as East Tualatin Plains.

The neighborhood was one of the most basic associations of rural frontier life, a union of persons with similar backgrounds in small, fairly homogeneous communities, each slightly different from the rest. ${ }^{74}$

73 Bowen, The willamette Valley, 29; Bourke and Debats, "The structures of Political Involvement in the Nineteenth Century: A Frontier Case," 18.

${ }^{74}$ Bowen, The willamette Valley, 53. 
Bowen further holds that the growth of rural neighborhoods contributed to the development of two dissimilar frontiers. One was rural, composed of clans of westerners. The other was urban, composed of unmarried men of New England and foreign birth. ${ }^{3}$ The settlement patterns and the subsequent development of Hillsboro suggests that Bowen's dichotomy existed in microcosm on the East Tualatin Plains.

The clustering of the several groups discussed in Chapter 2 created a network of self-sufficient neighborhoods that did not immediately generate a rural version of the urban center, that is, a pioneer town. The town grew out of the aspirations of the same kind of men who built the larger cities in oregon, single men from the east coast of the United states.

It is worth noting at this point that the East Tualatin Plains claims were established under the terms of the Provisional Government's land claim legislation, which predated the Federal cadastral surveys of the Tualatin Valley in 1851-52. The terms of this legislation allowed each white male married or single a full square mile of 1 and. These claims were based on surveys of the individual settlers own device. They took their line sightings off any prominent landmark, especially Mount Hood. In so doing, they provided these early claims with a wide range of polygonal shapes that contribute to the patchwork effect of 
the maps of land claims between 1840 and $1851 .{ }^{76}$

The system left each settler free to configure his claim to his own convenlence, be it cohabiting in a cluster with kin or countrymen, or more important to subsequent settlement, avoiding the inclusion of inferior agricultural land. Thus, East Tualatin Plain was settled with less than efficient density, the first comers taking the best $\mathrm{land}$ and leaving the less desirable to those who would come later. The Provisional Government Iand claim legislation unwittingly allowed the early settlers to establish a kind of land-based oligarchy of first families that would ensure their economic well-being and social status as much on the basis of chronology as actual merit and hard work.

The clustering of claims on East Tualatin Platns is best shown by use of a series of maps drawn from the topographical survey carried out in 1851-52.77 (see fig. 3).

\footnotetext{
7sBenson, "DLC", Mss., Washington County Museum, Washington County, 1-2.

77The observations on the East Tualatin Plains community come from an analysis of the settlement patterns as revealed in the 1845 provisional Government census and the 1850 Federal census, as well as data abstracted from the Donation Land claim records. The claims are arranged in five chronological groups, each with its own distinguishing historic characteristics. These groupings are not intended to be precise. The lines between them are blurred, as much by inaccuracies in the records as by a somewhat arbitrary rationale in forming them. Nonetheless, they offer a means of looking at settlement patterns that demonstrate how the clustering of neighborhoods developed.
} 


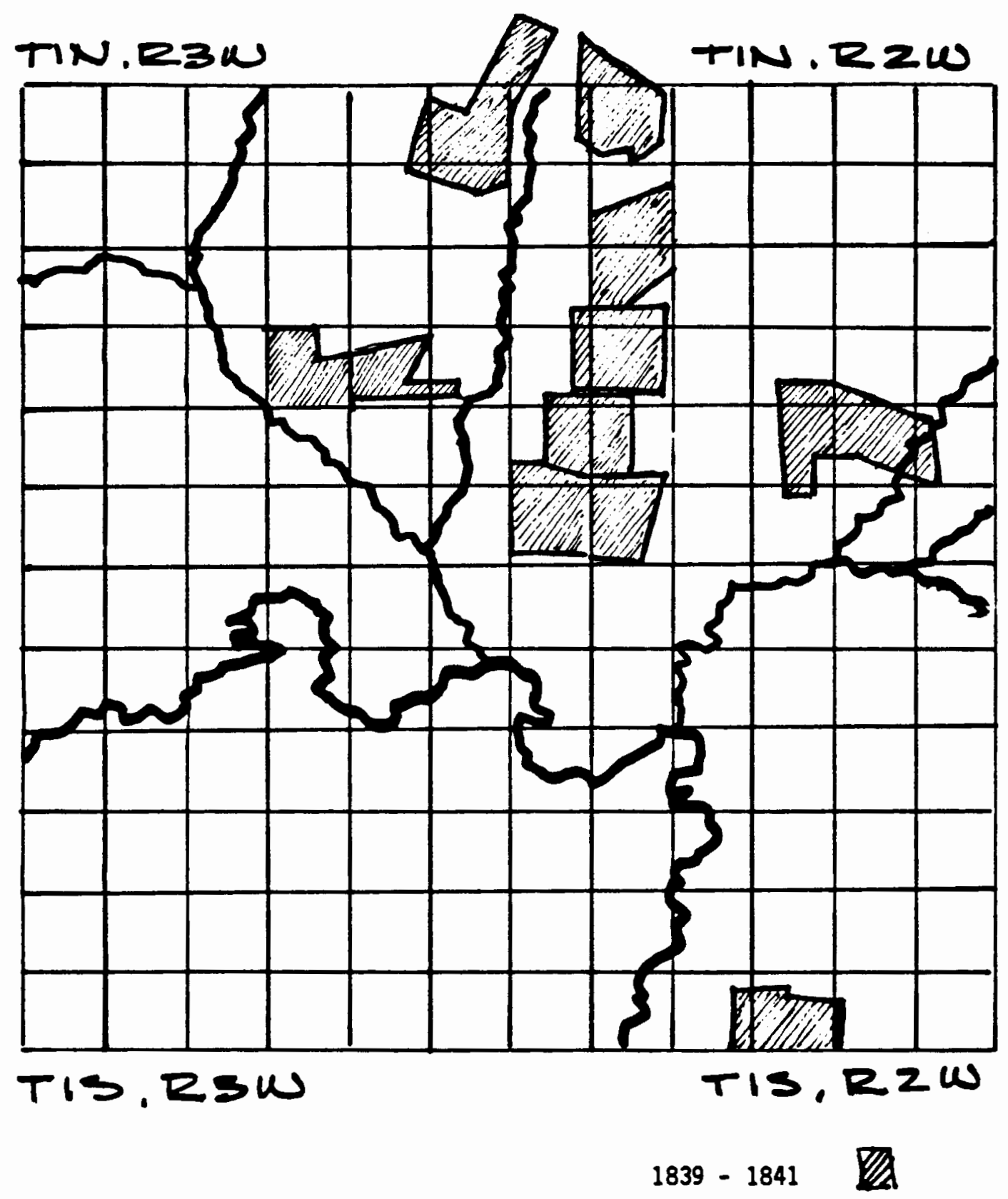

Figure 3. Donation Land Claim Patterns, East Tualatin Plains, 1839 - 1841 . 
44

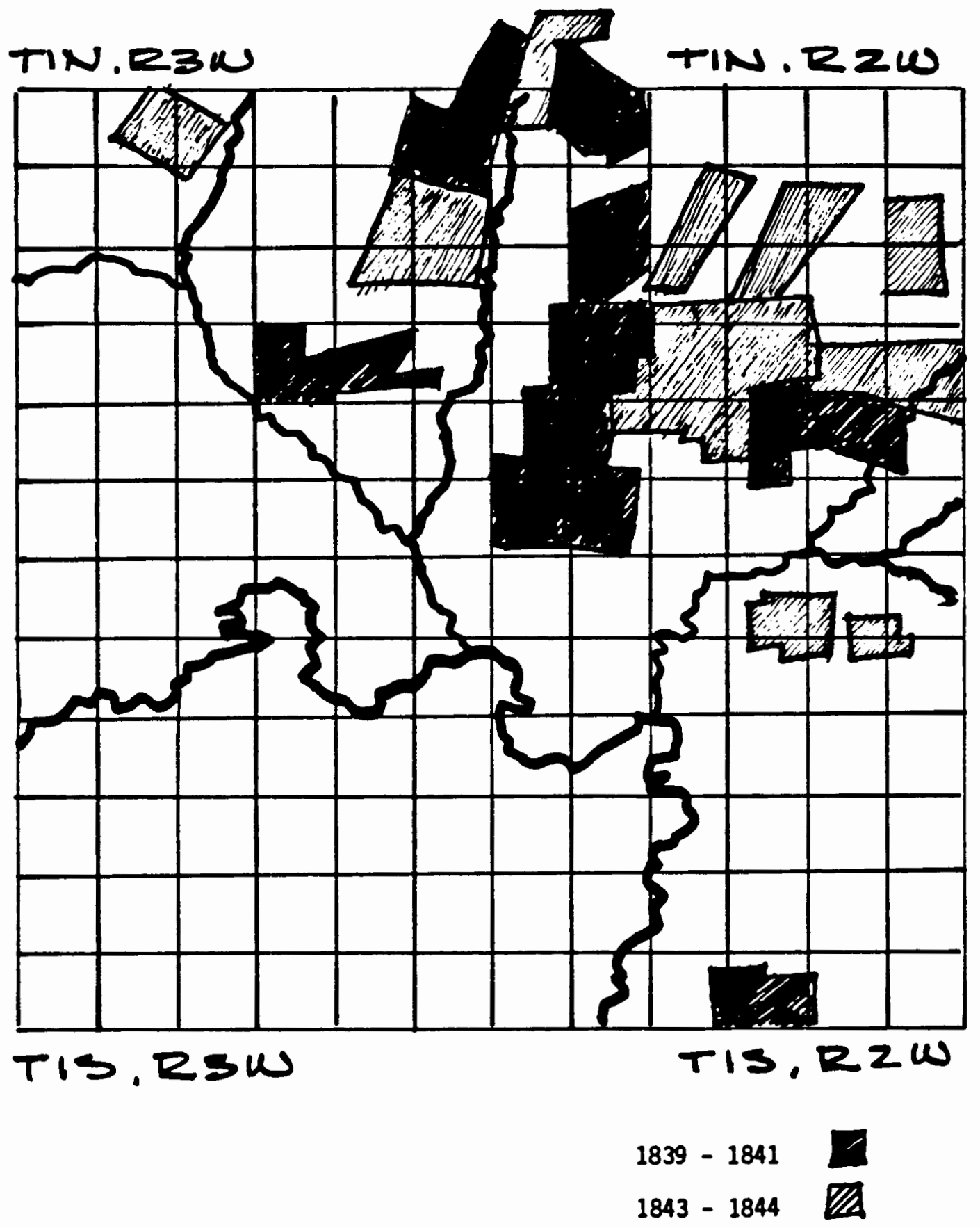

Figure 4. Donation Land Claim Patterns, East Tualatin plains, $1839-44$. 

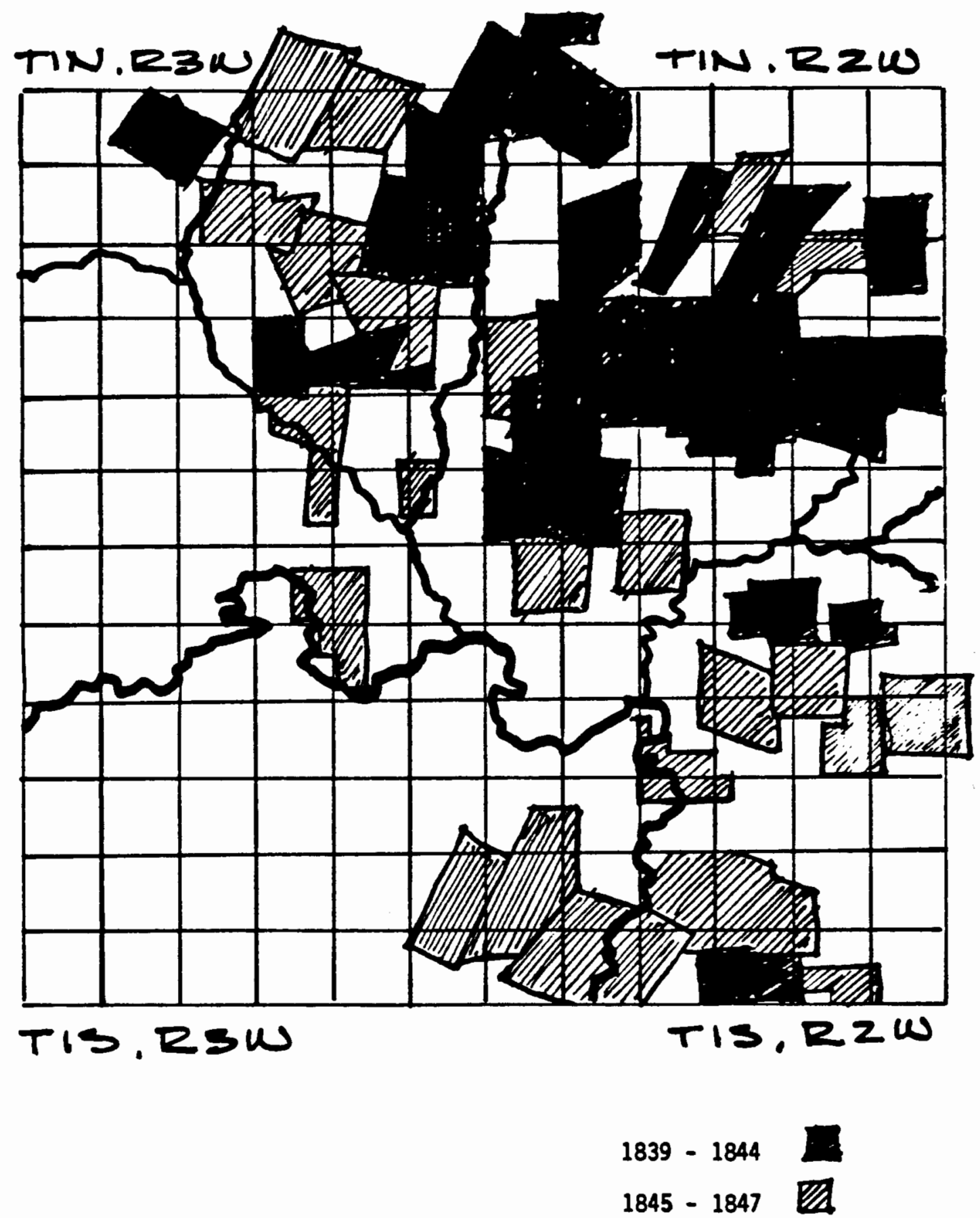

Figure 5. Donation Land Claim Patterns, East Tualatin Plains 1839-4 7 . 


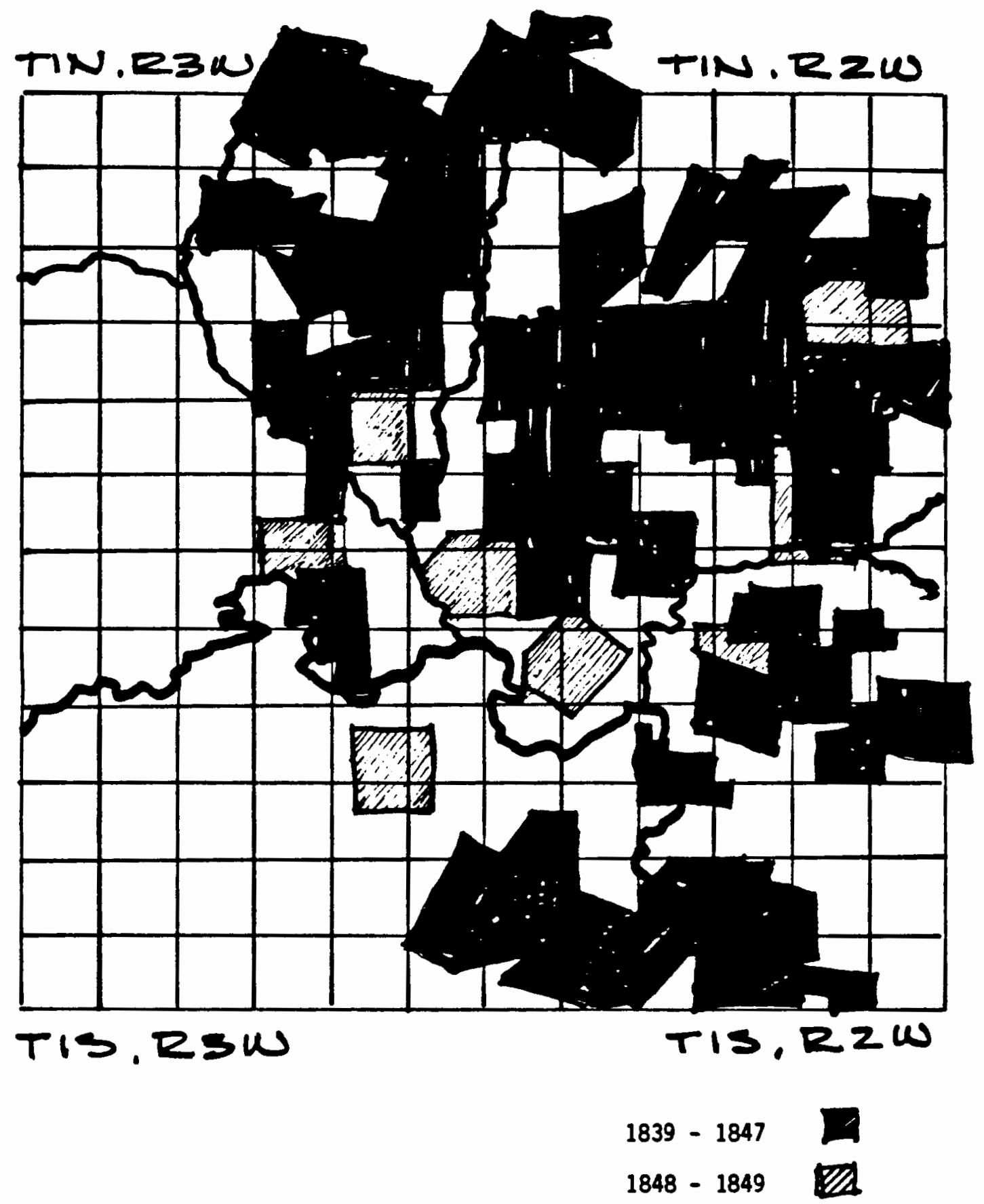

Figure 6. Donation Land Claim Patterns, East Tualatin Plains 1839-1849. 

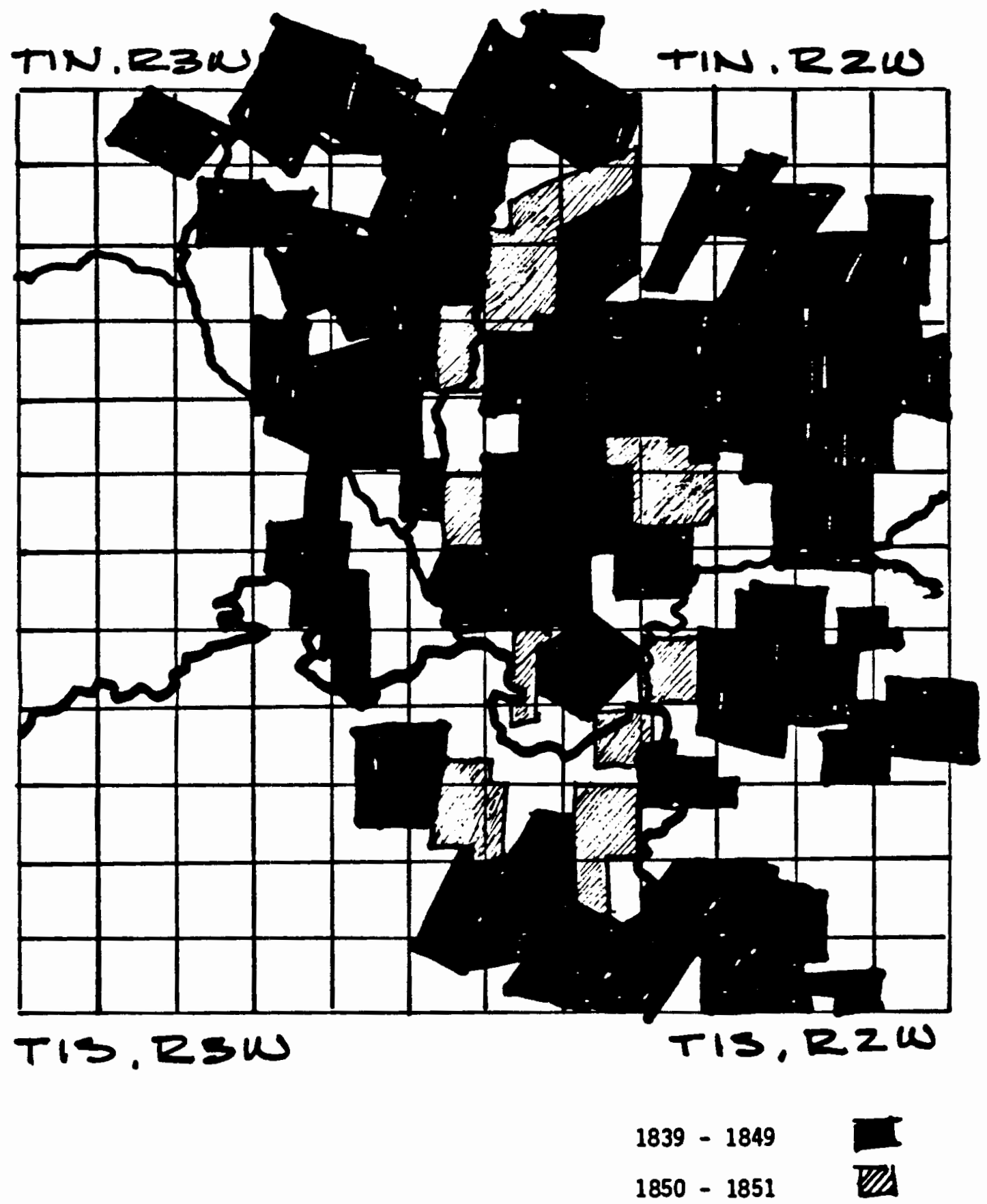

Figure 7. Donation Land Claim Patterns, East Tualatin Plains, $1839-1851$. 
$1839-42$

The first group of claims represents the initial settlement of the East Tualatin Plains during the years 1839-1842. These were the years during which three of the area's four principal groups settled for the most part: the American fur trappers, the independent protestant missionaries and the Anglo-Canadians from Puget sound. There were fourteen claims established in this period on the East Tualatin Plains, five by the fur trappers, six by the Anglo-Canadians, one by a New England missionary and three by American stragglers.

Some of the claims of the American fur trappers were arranged piimarily in the northeast township of East Tualatin Plains, located along the western edge of a level prairie just east of the east fork of Dairy Creek. Others were on the opposite side of the prairie, to the southeast along Rock Creek. These settlers conformed to the predilections of their western state origins in settling on the edge of prairies, such as at sugar creek.

The American fur trappers called theit claims the Rocky Mountain Retreat in honor of their former occupational habitat. ${ }^{\text {B }}$ It was the earliest neighborhood cluster on the East Tualatin Plains. It may have determined in part how subsequent settlement would fill in the rest of East Tualatin Plains. J.S. Griffin, the congregational minister, 
settled immediately south of Meek, and the American

"stiagglers" settled to the south of Griffir, establising a clain of claims running north-south along the east fork of Dairy creek, an edge of the single largest prairie at East Tualatin Plains. The Anglo-Canadians arrived somewhat later than the American fur trappers. They established claims along the eastern and western ecige of the next prairie to the west of the Americans, located between the west and east forks of Dairy creek. These claims followed the same settlement patterns of the Americans. That is, they clustered on the edges of prairies.

\section{$1843-44$}

The Great Migration of 1843 brought the first significant American immigration to the oregon country. Approximately 800 people arrived that year. 79 The migrations of 1843 and 1844 produced a total of thirteen claims on the East Tualatin Plains, alcng with one more Anglo-canadian from the Puget sound venture. of the thirteen claims, two were established by families from England. The others were of settlers from kentucky, Arkansas, and New York. There was also a New Englander from Massachusetts. 80

79 Bowen, The willamette Valley, 12.

oone of the settlers who established a claim in this period remains unidentified as to origins. 
Eight of the new claims were taken in the center of the largest prairie already settled by the American fur trappers and others. These were the first of the claims to begin filling in the open agricultural land on the plains. The discernable clustering during this period consists of the three New Yorkers who established their claims close to one ancther, and the Englishman settling next to a countryman who had arrived earlier. The remaining claims were scattered to the northwest, on the western prairie, and to the southeast, along the edges of Rock Creek and its tributaries.

\section{$1845-47$}

The greatest number of arrivals in the 1840 s accrued between 1845 and 1847 . In 1845, approximately 2,000 came, in $1846,1,000$, and in 1847 as many as 5,000. It was the last sizeable immigration to oregon prior to the events of the whitman Massacre and the California Gold Rush, which affected the direction and scale of subsequent settlement. ${ }^{\mathrm{a}}$

The impact of the 1845-47 immigration on East Tualatin Plains was dramatic. Twenty-six claims were established in three years, 10 in 1845,6 in 1846 , and 8 in 1847 , almost a doubling the number of claims established in the preceding five years.

The settlement that occurred between 1845 and 1847 
produced the first real evidence of significant clustering on East Tualatin Plains. Perhaps the most interesting consisted of three Kentuckians and two North Carolinians who settled along the portland-Lafayette road near what later became the Harris ferry over the Tualatin River. The Portland-Lafayette road was a major roadway during this phase of settlement, located on the southern edge of East Tualatin plains. The road, and later the ferry crossing, served as a magnet for a cluster of settlers with common kin or states of origin. slightly to the northeast of this area, another roadway cluster formed along a northern branch of the same road. It was a less related crouping, with representatives from four different regions of the United states. It was a disparate cluster that, notably, produced social strife in the future. az

To the northwest, on the western prairie, two Kentuckians and a Missourian joined another Kentuckian already there. All three of these newcomers shared a common family name. Two other west prairie newcomers added a midAtlantic leavening to this cluster, coming as they did from Pennsylvania and Maryland. The final clustering took place at the southeast corner of east prairie. Two New Yorkers and one Englishman settled to provide a mid-Atlantic foreign born presence to balance the Kentucky and North

- Bourke and Debats, "The structures of Political Involvement in the Nineteenth Century: A Frontier Case," 1718. 
Carclina families already there. This development fcreshadowed a distinctiveness for this particular nezghbo:hood that also manifested itself in the next few yeara.

After the immigration of $1845--1847$, the northeast prairie was almost full, while the southeast township, a mix of prairie and marshy botton land, was beginning to fill. $B y$ the end of 1847, fifty-two claims had been established. two thirds of the entire number of claims settled by 1851 . These fifty-two claims were found in the best and most desirable agricultural land in the Northern willamette Valley. ${ }^{\text {s }}$

\section{$1848-49$}

only eight settlers established claims on the East Tualatin Plains during 1848-49. All of these were equaliy cistributed in the four townships as in-fill. There was no significant new clustering of any of the settlers arriving during this period, merely the reinforcement of earlier clusters. For example, a Missourian and a Kentuckian joined the north road cluster of fellow countrymen in the southeast township. Also, a second claim was established on the smaller and less desirable southwest township. The combination of the river and the large amounts of marshy 
bottomland made this part of East Tualatin Plains a poor second even to the other townships. By 1850 the existing settlement patterns determined the location and number of neighborhood clusters at East Tualatin Plains. New clusters were no longer possible.

Perhaps the most noticeable aspect of who settled at the end of the 1840s are the three additional kentuckians, the largest state grouping of the period. Kentuckians constituted an abnormally high percentage of settlers at East Tualatin Plains, followed by Ohioars. The German settler constituted an even rarer anomaly, a non-English foreigner. One other item of interest occurred in this year. David Hill, whose claim was established in 1842, died leaving his wife Lucinda as heir in 1849. She soon married Wheelock simmons, who subsequently took Hill's claim in his own name.

The new law did have an effect on East Tualatin Plains. It altered the way all claims, existing and new, were established, and placed the emphasis on married rather than single men. All claims established before 1850 had to be re-submitted under the new law. It also required new claims to conform to boundaries established by the Federal cadastral survey, commenced in June of 1851. Thus, all claims after 1850 had the handicap of having to conform to much more restrictive boundaries while trying to accommodate 
themselves to the remaining open land on the plains. ${ }^{4}$

$\underline{185.0-51}$

Even with the new law, there was not a massive rush to East Tualatin Plains in the years following. There were eleven claims established, all as somewhat evenly aistributed infill between the existing claims. In geiseral, this infill fed the clustering already in place. Another New Yorker joined the cluster in the neighborhood of the future town of Hillsboro. Another Missourian joined the northern roadway cluster in the southeast township.

All the land in the Tualatin Valley was said to be claimec by 1851. That was certainly the case by 1855, a fact confirmed by the surveyor-general's report of 1857.85 East Tualatin Plains was largely settled in terms of the best open land by 1847. Such would support the claim that oregon probably would have been settled almost as rapidly without the benefit of the Donation Land Law, only with different settlement patterns.86

The clustering effects on East Tualatin Plains as a result of settlement between 1840 and 1850 are as follows. The northeast prairie had clusters of American mountain men

\footnotetext{
* Robert L. Benson, "Donation Land Claims," Mss. collection, hashington county Museum, Washington county, oregon.

es Johansen, "The Land Base of Oregon's Economy," 1 .

swilliam G. Loy, et al, Atlas of Oregon, (Eugene, or.: University of Oregon Press, $19 \overline{7(t), 9 .}$
} 
and Anglo-Canadians and mid-Atlantic/New England farmers, more or less oriented to their own immediate area of claims. The northwest prairie had clusters of Missourians and Kentuckians, as well as Anglo-Canadians. These too were somewhat self-contained within their own prairie. The smaller prairies to the southeast had two clusters, both oriented along major roadways that acted as magnets to the clustering. Most of these farmers were from kentucky and Missouri, with a few southerners and others thrown in. Again, these appear to have been self-contained rural neighborhoods, distinguished by little more than a ferry or local school house. ${ }^{3}$, only the southwest prairie areas, very limited by the topography of this township, resisted any significant clustering patterns. There is no real pattern here, as it was the least desirable location at East Tualatin Plains.

For the purposes of this study, the cluster around what would become Hillsboro, at the southwest corner of the northeast prairie is most interesting. It was a split cluster composed of a Kentuckian (Isaiah Kelsey) and a North Carolinian (Richard williams), balanced by three midAtlantic states settlers, two from New York (Dr. Ralph

TThe 1851-52 General Land cffice survey maps of the four townships composing East Tualatin Plains show the location of actual cultivated tracts of land, house, schools, mills and ferries. The location of these features reflects the clustering along roadways and at road intersections. See figure 8 . 


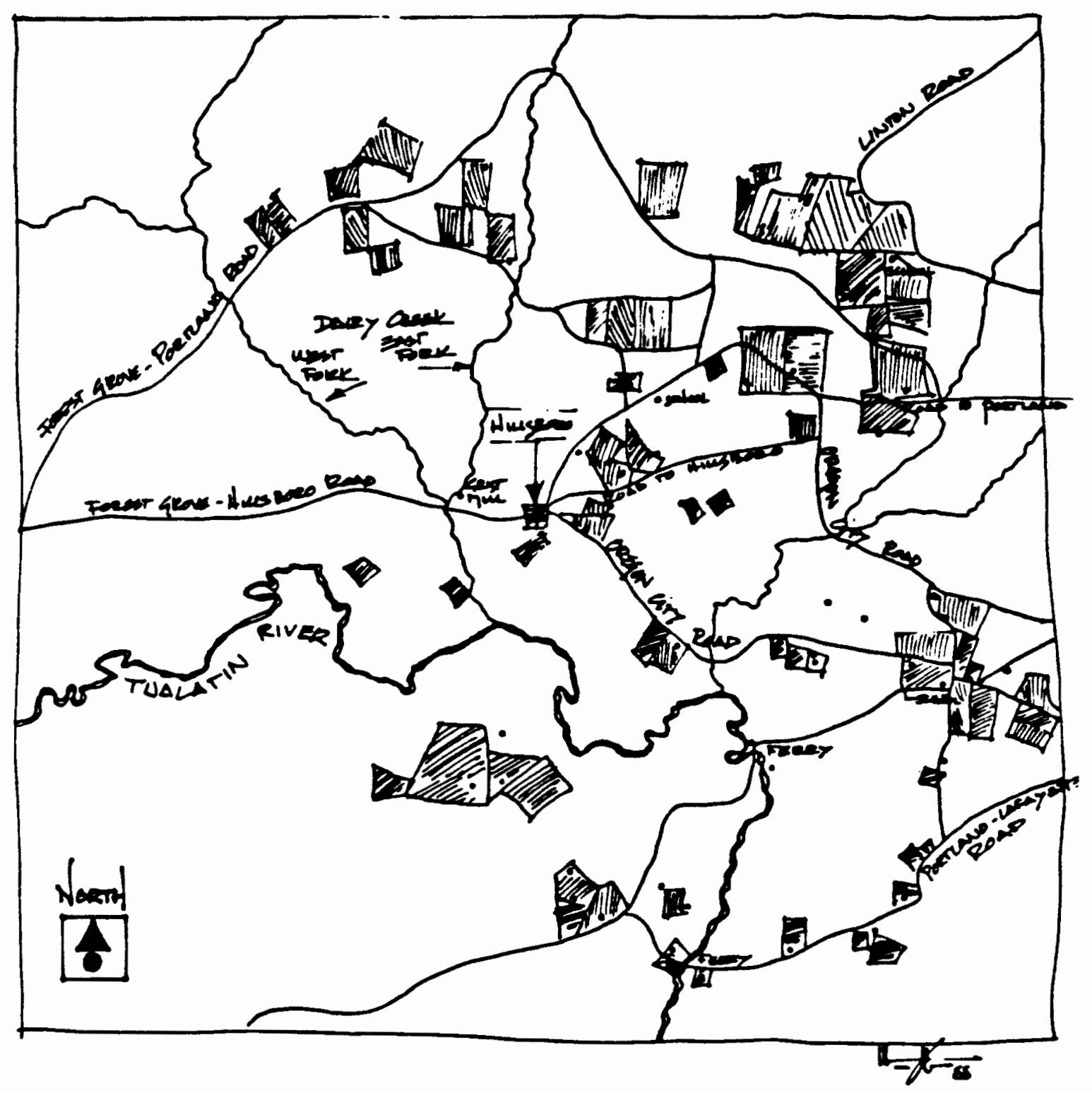

Figure 8. Cultivated Land and structures, East Tualatin Plains, 1852. 
Wilcox, C.D. Wilcox) and one from Pennsylvania (Wheelock Simmons). ${ }^{8}$ Another Pennsylvania man, Abraham sulger, was also a part of this cluster by virtue of establishing his general store in its midst. His land claim, however, was located some three miles to the southeast.

The importance of this particular cluster relative to all the others is that it is the one which fell heir to the county seat. The combination of settlers in this cluster is an odd mix. It is not urique, even at East Tualatin plains, but it was not as homogeneous as some of the others, nor located on any major trans-valley road or waterway. If one looks at the origins of settlers immediately adjoining the cnes just mentioned, that is, extend the cluster a bit, two more New yorkers and two Englishmen are included. It then becomes a significantly different cluster from any of the others.

It is dangerous to put too fine an edge on this particular cluster's composition, as it is impossible to identify these clusters with any precision other than by the refererces cited earlier about distance and neighborhoods and common sense. However, there does appear to be a link between the establishment of the county seat in the midst of this particular cluster and Bowen's discussion of the townbuilding proclivities of New Englanders and foreign-born

sosimmons acquired the land claim of David Hill, who was from Connecticut. The mid-Atlantic connection was maintained. 
men.

The establishment of the county seat in the midst of a cluster dominated by Mid-Atlantic settlers with more than substance farming as their goal is more than coincidence. David Hill ard Abraham sulger appear to have been central to the establishment of a towr. and county seat. Simmons, Wilcox and others were town pillars-in-waiting, men who would assume leading economic and professional roles once the town was founded. There is no proof that Hill invited Sulger to establish his store in the cluster. But as sulger's own land claim was three miles to the southeast at a potentially lucrative ferry crossing on the Tualatin River, he had to have a reason to move to Hill's claim. That reason was provided by the town-building spirit of Hill and others in the neighborhood. The civic aspirations of Hill's neighborhood will be further examined in chapter 6. 


\section{CHAPTER V}

\section{LAND AND COMMUNTTY AT EAST TUALATIN PLAINS}

A key issue relating to the East Tualatin Plains is the basis for its economy: 1 and. This was an agricultural frontier, and as we have seen, wealth and position in the community was based on land; who got how much and when. In looking at the effects of clustering relative to the rise of Hillsboro, it is worth considering some of the legal and social aspects of how the settlement community was based on the land. A consideration of those parameters will put the establishment of the town of Hillsboro into sharper focus relative to the pioneer town as a link between the urban and rural frontiers.

Recent scholarship concerning the rise of towns on other frontiers has established that many of them were speculative ventures. Robert Dykstra's account of five towns on the cattle frontier points out that these towns were the result of a speculative effort by the entrepreneurs who acquired massive land grants, platted towns and promoted them in order to reap the profits from promoting commercial and residential real estate. On other western frontiers, 
the pattern was the same. " In these instances, the central figure was the frontier entrepreneur-speculator. They were the key to fostering an urban impulse and eventually isolating the frontier farmer.

This interpretation, however, does not fit oregon. speculation on the oregon frontier was affected by unique characteristics of the territory. Oregon was far removed from the nation, and thereby it escaped the historic pressures that limited the duration of those frontiers to five to ten years. 90 As a result, here the pre-urban frontier lasted a good deal longer. The frontier isolation of East Tualatin Plains/Hillsboro lasted at least thirty years, from 1840 to 1871 , when the rallroad arrived. The duration of such isolation had a profound impact on the evolution of the town. Even with the advent of rail service, and incorporation as a city, Hillsboro never became a commercial center. The duration of Hillsboro's isolation as a farm-to-market town precluded it every becoming a speculative boom town.

East Tualatin Plains' history had two phases. The first was settlement, 1840 to 1850 . The second

9Robert Dykstra, The Cattle Towns, (New York: Alfred A. Knopf, 1968). See Also, Don Harrison Doyle, the Social order of a Frontier Community. Jacksonville, Illinois, 18251870, (Urbana, Ill.: University of Illinols Press, 1983).

o Merle Curti, The Making of An American Community, (stanford, Calif.: stanford University Press, 1959). 
significantly longer, even protracted, phase encompassed the creation and evolution of the town of Hillsboro, from 1850 to 1890. The first phase was characterized by the saturation of settlement on the best agricultural land by the first comers, and the platting of the town. The second phase was characterized by the growth in population of the settled agricultural community and the slow emergence of the town of Hillsboro as a farm-to-market town.

Within the first phase, it is important to establish the role speculation played, or did not play, in the economy of the agricultural community. The evolution of the pioneer town of Hillsboro differed from other frontier towns in that it reflected a lower-key form of speculation in keeping with the values of the dominant agrarian society.

The oregon frontier was populated in large part by those who fled the encroachment of the highly competitive market economy of evolving nineteenth century capitalism. Land speculation and town boosting were perceived by the agrarian settlers who immigrated to oregon as twin evils to be avoided on the new frontier. The sizeable and lucrative land claims of both the Hudson's Bay Company and the established Methodist Mission, already in place at the time major American immigration began, were good examples of such evil. The early settlers acted to control speculation through the mechanisms of a provisional American government, established in 1843. 
In 1844, the Provisional Government's legislative committee amended its original land act to eliminate the special mission grants, and also required that all claimants make improvements in order to establish a bona fide intention of occupation and cultivation. Further amendments to the land act were made that same year. These required formal adult occupancy of all established claims as a remedy to the previous practice of holding land in children's names. 1 Furthermore, provision of a new organic Act in 1845 prohibited settlers from laying claim to whole townsites. This measure aimed at John McLoughlin of the Hudson's Bay Company and his town at oregon City.92 The effects of these legislative restrictions circumscribed outright speculation. In addition, land claimants were prohibited from selling their claims until they had established clear title. Clear title, or "proving up" was accomplished by making the improvements required by law over a given period of time.

Thus restricted, settlers arriving after 1845 had to resort to illegalities in order to acquire farms. Many settlers did indeed purchase their claims from other settlers, only by the subterfuge of buying the improvements and not the land. The buyer simply assumed responsibility for proving up on the original claim. Between 1843 and

\footnotetext{
-1Carey, A General History of Oregon, 343 .

2Throckmorton, Oregon Argonauts, 33.
} 
$1850,25 \%$ to $33 \%$ of the overland immigrants purchased their claims in the Northern willamette Valley. Illegal Iand transfer become so rampant that, by 1842 , the oregon Spectator warned against 1 and and town speculation." $3 Y$ 1847, most of the good open land had been claimed at East Tualatin Plains.

The real issue concerning available land was perhaps less one of speculation and more an open competition between the early settlers and those who arrived later. After 1844, when the western American farming settlers began to arrive in large numbers, there was a growing resentment concerning both the size of the early claims versus the amounts actually in production, and also the kind of people who held those claims.9.

Most claims were 640 acres, but due to labor and technological limitations, the nature of the frontier economy and society, most claims usually had less than 100 acres in production during the early phase of settlement. Thus it appeared that the first settlers had more land than they reeded. In addition, the claims staked out under the Organic Act of the Provisional Government were, for the most part, neither surveyed nor fenced. As a result, just what land belonged to whom was not always clear. To further compound the matter, some of the early settlers who held

sBowen, The willamette Valley, 71.

94 Tobie, No Man Like Joe, 200. 
large claims, especially on the East Tualatin Platns, were foreigners of mixed blood, or Americans married to Native Americans. The later arriving western Americans did not hold such settlers in high regard. All of these factors combined to create a resentment among the later arriving settlers.

David Lenox, a New York settler of 1844 left a succinct example of that attitude:

As to the population of the country, it is a mongrel set but fast receding. The Hudson Bay Company men have nearly all married Indian women, and some of our old American mountain hunters have also taken Indian women. The country is filling up with white families. 95

The increasing competition for land, compounded by the other factors discussed above, led to extra-legal action on the part of some settlers. Claim-jumping became a problem on the oregon frontier, including Tualatin Plains. As William Bowen has observed:

During his first ten years of residence on the Tualatin Plains, A.T. Smith had to warn off trespassers on two separate occasions. So serious did the problem become on the plains that his neighbors on at least one occasion gathered at the Methodist meeting house for an anti-claim jumping party.9s

Since claim jumping appears to have been the concern it was, it is possible that on the Tualatin plains at least, there was less actual sale of surplus land or unwanted claims than the figures cited above for the Northern

osletter written by David T. Lenox to George Swan, in Rushville, Ill1nois, 9 March, 1845. Mss. 57, washington County Museum, Washington County, Oregon.

"Bowen, The Willamette Valley, 72 . 
willamette Valley. Those who settled East Tualatin Plains were persistent. They remained in place once the claim was established. There is no evidence that 1 and speculation was a major interest of the early settlement population.

While the land 1tself was the foundation of the community, there was from the beginning a distinct social order on the Tualatin plains that reflected the unusual mix of settlement groups discussed above.

on other frontiers, community was established by persistent families in association. 9 Many of the settlers who established claims on the East Tualatin Plains had common origins, but there are only a few example of families coming out and establishing clusters. The Cornelius family is one that did so. On a territory-wide basis at least $40 \%$ of the households in 1850 had kinship ties with one other household or more.9 This is not surprising, given that extended families often came west together, or followed in stages. It would appear that once in oregon, they did not cluster but spread out as circumstances warranted. Kinship on the East Tualatin Plains therefore developed not from extended family clustering but from marriage between the families of the earliest settlers.

Many of the early settlement families were large, including several older children of marriageable age. Some

97 Faragher, sugar Creek, 56.

sBowen, The willamette Valley, 52 . 
of the marriages between early settlement families can be attributed to the provisions of the Donation Land law of 1850 that allowed a married couple 640 acres versus 320 for a single man. But not all. Out of 94 persistent heads of households (those with established claims in 1850), only 17 were married in the oregon Territory, and 12 were married prior to the passage of the Donation Land Law.9.

Many of these marriages took place at East Tualatin Plains. J.S. Griffin, the congregational minister at East Tualatin plains, performed 16 marriages involving families with established land claims at that locale. Eleven of these marriage occurred before 1850.100 BY 1851 , at least 22 of the families living at East Tualatin Plains were married after arriving in oregon, one half of that number being married as a direct result of settling at East Tualatin Plains. Kinship ties may have existed between $40 \%$ of the households in oregon Territory by 1850 , but the percentage of kinship relations at East Tualatin Plains would appear to have been less of a factor in forming the immediate community than other factors, above all

sbased on an analysis of information abstracted from the applications of those settlers who submitted land claims under the Donation Land 1 aw of 1850 for East Tualatin Plains. Genealogical Material in Oregon Donation Land Claims. Abstracted from Applications, (Portland, or .: Genealogical Forum of Portland, 1957)

100 Records of Marriages by Rev. John Smith Griffin, Tualatin Plains, O.T., Record Book of the First Congregational Church of the Tualatin Plains. Griffin Papers. Mss. 1075, Oregon Historical Society, Portland, oregon. 
clustering.

Religion is another factor that played a central role in forming the society at East Tualatin plains, perhaps more so than kinship. Protestant revivalism provided a facet of cultural homogeneity that promoted community bonding on a broad scale. ${ }^{101}$ openly identified religious affiliation also offered a means of social prominence in an agrarian frontier society. Social leadership was provided by the religiously associated first settlers whose large claims provided them with the other leadership prerequisite, wealth. 202

In examining the religious orientation of East Tualatin Plains settlers, another anomaly surfaces regarding the nature of the settlement community. East Tualatin Plains had an unusual combination of denominations. In general, the rural frontier tended to be populated by Methodists and Baptists, while Presbyterians and Congregationalists dominated the urban areas. ${ }^{203}$ on the Tualatin Plains, however, a group of congregationalist missionaries headed by J.S. Griffin established a church in June of 1842. It was the first organized religious institution on the plains, and was initially centered on Griffin's claim at East Tualatin

101Faragher, Sugar Creek, 169-170.

102 Bourke \& Debats, "The structures of Political Involvement in the Nineteenth Century: A Frontier Case," 11. 103Bowen, The Willamette Valley, 96. 
Plains. ${ }^{30}$ Most of the early congregation was of New England stock. While these settlers were hardly urban in focus, they had less in common with their neighbors in terms of their religious faith. The Congregationalists were a devout lot, much given to daily prayer and the devotion of sundays to religious meetings. In addition, congregational settlers engaged in frequent camp meetings of several days duration. The diary of Alvin Thompson Smith, one of the stalwarts of the Congregational community, affirms that on average between 40 and 50 days a year were devoted to religious activities. ${ }^{105}$

The Congregationalists were among the first settlers, and the combination of religious fervor and relative wealth based on their early arrival provided them with a degree of social and moral leadership that had significant influence on the Plains. J.S. Griffin led an effort, for example, to get the American mountain men and the Anglo-Canadians to marry their Native American wives within the church. ${ }^{106}$ clear title to all the American claims depended on the establishment of a provisional American government. Griffin wanted a united, Christian American community on the

zoeJ.s. Griffin, Record Book for the First Congregational Church of the Tualatin Plains. 1.

108A.T. Smith, Diary, 1840-1853, Mss.8, Oregon Historical Society, Portland, Oregon.

$105 \mathrm{~J} . S$. Griffin, Marriage Records, Record Book for the First Congregational Church of the Tualatin Plains. Three such marriages are recorded in the fall of 1842 . 
Tualatin Plains to support the establishment of such a government. 107

It is also likely that Griffin and the other Congregationalists who were intent on building a new Christian society on the Plains could not accept cohabitation with Native American women as a feature of that new society.10 Their moral authority was strong enough that others dared not ignore it if they wanted to prosper in a social world that revolved around religlous meetings and services.

However, there were countervailing forces at work. J.S. Griffin's overzealous nature compromised the Congregationalist hold on East Tualatin Plains. He proved to be too righteous even for some of his own flock. By 1845, Griffin's congregation split, and a separate congregation was formed at West Tualatin Plains centered on the claims of Harvey Clark, Alvin Thompson Smith, and William Geiger. In addition to Griffin's zeal, the distance between his claim and the west Tualatin Plains members of the congregation was considered a hindrance to their regular worship. ${ }^{109}$ The Congregationalists were to flourish at west

${ }^{107 R i c h a r d s o n, ~ " J o h n ~ S m i t h ~ G r i f f i n, ~ I n d e p e n d e n t ~}$ Missionary to the Indians and Tualatin Plains Ploneer," 35. Griffin persuaded Joe Meek to marry his Native American wife Virginia with the argument that such a marriage would secure his land claim. Tobie, No Man Like Joe, 114.

100 Tobie, No Man Like Joe, 114.

109Richardson, "John Smith Griffin," 37-41. 
Tualatin Plains, founding an academy by 1849. They provided the dominant social and moral order for the pioneer town of Forest Grove that grew up around Tualatin Academy. ${ }^{10}$

other denominations existed at East Tualatin Plains in name if not in force. In July of 1843, a Methodist camp meeting was held on the plain.111 who actually organized the meeting is unknown. It would appear that many who attended were not Methodists, including A.T. Smith who speaks of it in his diary. Society was too limited to turn down a social occasion.

It was an ecumenical community (in a Protestant sense) at East Tualatin Plains. Even J.S. Griffin accepted a Methodist couple into his congregation in 1845 , on the understanding that the union was temporary until a Methodist congregation could be organized.112 The lack of such an congregation in 1845 indicated that the 1843 Methodist camp meeting was organized by an itinerant Methodist rather than any permanent representative of that faith.

on 25 May, 1844, a Baptist congregation was organized by five settlers clustered on the northeast edge of East Tualatin Plains. The principle members were David $\mathrm{T}$. Lenox

110 R.P. Matthews, "The cult of True womanhood and Women's Associational Activities on the Tualatin Plains, 1840 - 1880," 25 February, 1988.

121 Toble, No Man Like Joe, 114.

$112 \mathrm{~J} . \mathrm{S}$. Griffin, Record Book for the First Congregational Church of the Tualatin Plains. 
of New York and Henry Sewell of England.123

The Baptist records display a competitive tone between them and the other denominations.12. The Baptist's easygoing religious practices conflicted with the

Congregationalist's fervor. As J. Oliphant has observed:

Western Baptists were apparently content with a monthly church service, were not content to support adequately a gospel ministry, and were not trained to contribute generously to the missionary cause and to other benevolent enterprises of the day. ${ }^{13}$

Such attitudes would be more in keeping with many of the settlers at East Tualatin Plains who came from the western states.

While the founding members of the various denominations may have been in religious competition, it would appear it was based more on doctrinal variations than conflict over a spiritual dominion at East Tualatin Plains. The religious boundaries of East Tualatin Plains were not as sharply drawn in the minds of many of its protestant residents. This phenomenon of generic protestantism was commented upon by clergymen of the day. W.C.V. Johnson, an Episcopalian

$113 \mathrm{~J}$. Oliphant, "Minutes of the west Union Baptist Church," Oregon Historical Quarterly 1(1900), 247. The Baptist congregation left the most detailed records of the early religious groups at East Tualatin Plains. Those records, coupled with the clustering of the Baptists in one part of East Tualatin plains provide a sense of how religion played a central role in forming the community. Church," 249.

110liphant, "Minutes of the West Union Baptist 1xsoliphant, "Minutes of the west Union Baptist Church," 251. 
teacher from New York, referred to the communities on the Tualatin Plalns as "nothingarians," in that all the various congregations were too small for anyone to dominate. ${ }^{12}$ The various protestant congregations provided a framework for social cohesion amongst the neighborhood clusters based on a familiar and acceptable moral order.

The records of the West Union Baptist Church provide a sense of East Tualatin Plains moral order. In January and February of 1849 , J.Q. Zachary is mentioned as the focus of concern regarding his "waywardness." He was subsequently dismissed from the congregation for disorderly conduct and refusing the call of the Church. In August, 1850, sisters zachary and Constable appear in the records as having a contretemps that required the intervention of the congregation.117 By December, Sister Zachary, being considered disorderly and unworthy of fellowship, was expelled for slander against sister Constable. In January of 1851, Daniel Zachary is charged with dancing and frolicking at parties. In all such cases various members of the congregation, who were neighbors of the accused, were charged with visiting the wayward brethren and establishing the facts of the case for the entire congregation to decide

116Bourke \& Debats, "The structures of Political Involvement in the Nineteenth Century: A Frontier Case," 16.

117 The Zachary and constable claims adjoined each other, and were part of the Baptist cluster on the northeast prairie of East Tualatin Plains. 
on.11. Thus the entire community was no doubt aware at all times who was behaving properly and who was not. It was a moral order that transcended denominational distinctions.

There is other evidence of a pervasive moral order based on evangelical protestantism, ranging from civil law to community activities. In 1846 , for example, William Johnson was charged with selling liquor to Caleb wilkins. In the same year, Mary otchin was charged with "lewdness." In 1850, Joseph Meek, William H. Bennett, Caleb Wilkins, Benjamin Cornelius, Archibald Wilks, Anderson Smith, George Ebbert and Joe McNamee were all charged by the county court with gambling at cards at a Hillsboro store.11s Three of these men were retired mountain men who no doubt did not share the view that playing cards was sinful or illegal.

All of these charges reflect not only a community but a territorial concern for a fairly high moral standard. Drinking, gambling and charges of lewdness could be construed as serious crimes in any society, but given the size and nature of East Tualatin Plains, such charges were probably not so much indicative of a collapse of society as they were reflections of the power-political as well as religious--of evangelicals. That some of the community

1100liphant, "Minutes of the West Union Baptist Church," 258-261.

119 Inventory of the county Archives of oregon, No.34. washington County, oregon, (Portland, or.: Oregon Historic Records survey, Works Progress Administration, 1940), 15. 
would fall afoul of that moral order was to be expected. The easy-going westerners accepted the imperfections of man, knowing that the moral order always offered redemption. 120 The concern over alcohol was reflected not only in the law, but also in the broadcast non-denominational temperance activities that took place throughout the willamette valley. As early as November, 1846, a Tualatin Plains Temperance Society was organized by J.S. Griffin at East Tualatin plains. Griffin's intent was to form an oregon-wide temperance movement union. ${ }^{22}$ In 1847 , a Grand Temperance Movement meeting was held in Oregon City, at which Griffin's neighbor, Joseph Meek was elected an officer.122 By 1848, the washington Temperance society was organized and meeting in oregon City. Reverend Harvey clark and Peter Burnett are mentioned as the Tualaty county representatives.223 of the men who led the temperance movement on the Tualatin plains, three were from East Tualatin Plains: a minister, a lawyer

120 There is an anecdote about Joseph Meek, who needed a cow for milk for his family. It seems the owner of the cow Meek wished to acquire had concern for Meek's somewhat casual soul and told Meek he could have the cow if he would pray for the redemption of his soul. Meek needed the cow, and being a practical man, agreed to pray on his knees for one-half hour in exchange for the cow. In Meek's mind it was a fair trade, and no doubt he meant his prayers. Victor, River of the West, 299-300.

22112 November, 1846 , oregon spectator; 26 November, 1846 , oregon Spectator.

22230 September, 1847 , Oregon Spectator

1236 January, 1848, Oregon spectator. 
and a prominent political figure.12* Religion, morality and social prominence went hand in hand.

But what was the nature of day to day life at East Tualatin Plains? How did it reflect the values of a premarket agricultural community, based on land, persistence and a strong moral order? How did it reflect clustering in neighborhoods? Fortunately, the diary of Alvin Thompson Smith, a settler of 1841 at west Tualatin Plains, has survived. Smith's reflections provide a detailed record of life on the Tualatin Plains during the early settlement period. Smith was one of the Congregationalist missionaries associated with J.S. Griffin. He was a New Englander, educated and quite a successful farmer. He was socially active and a community leader. His farm business put him in regular contact with many of the Tualatin plains' persistent settlers. Smith's diary details sufficient contact with the established residents of East Tualatin Plains that we can deduce a pattern of daily life.

william Bowen relies heavily on smith's diary in his work on immigration in the Northern Willamette Valley.12s Bowen does not, however, dwell on the correlation between work and social data that smith provided. such a relationship is significant in establishing the nature of

124 Meek served as Sheriff under the provisional Government and as U.S. Marshal under the Territorial Government. 225 Bowen, The willamette valley. 
the pre-market agricultural society of the Tualatin Plains. An analysis of Smith's diary provides a sense of the relationship between personal profit and community.

In order to analyze smith's diary, it is necessary to establish categories of activities that could be examined systematically. ${ }^{206}$ These are:

A. construction: work on barn, house, fencing, pens and bridges.

B. chores: work about the house, for example, cutting wood, hauling water.

C. cooperative labor: working with neighbors on land, buildings and crops.

D. worship/sabbath readings, holding and attending meetings.

E. livestock: buying, selling, tending and slaughtering.

F. crops: plowing, planting, tending, harvesting.

G. business/social affairs: visits to nelghbors, trips to East Tualatin Plains, Fort Vancouver, Linnton, Willamette Falls and Champoeg. ${ }^{127}$

226I am indebted to Robert $w$. Keeler for his contribution of these analytical categories.

127 In establishing quantities for each activity, it was necessary many times to somewhat arbitrarily assign certain days to a given category. Smith would frequently do several things in one day, and it was impossible to know how much of the day was spent doing what. Thus there is a certain amount of guesswork in the analysis of the diary. Further, the analytical time frame was taken from fall to fall, not within a calendar year. Smith's diary for the Tualatin 
In order to develop a succinct frame of reference beyond the seven categories of activity they have been further reduced to two basic groups:

1. farmwork: construction, chores, livestock and crops.

2. community affairs: cooperative labor, worship, business/social affairs.

This grouping highlights a major division in the frontiersman's daily life: those activities focused on the economic well-being of his family and farm and those oriented towards community and society. Business was a necessary component of his farm's economic well-being, but it often transcended mere subsistence farming. Smith's business affairs took him all over the Northern willamette Valley, and he was a man of considerable means within the West Tualatin Plains community.22o

By graphing the percentages of the two categories of activities, an illuminating pattern emerges. The patterns reflect the parameters of the primary settlement of the Tualatin Plains, 1841-1847, as discussed above. Smith spent

Plains began in the fall of 1841. It seemed as conventent a time frame as any, and it has the added merit of reflecting the agricultural cycle of harvest to harvest rather than the calendar year. The intent of the analysis was not to achieve precise measurements but to establish a sense of the pattern of Smith's daily activities over a number of years.

220 for example, Smith acted as paymaster for the fledgling Tualatin Academy in the 1840 s and 50 s, honoring notes of payment to mechanics made out by the Board of Trustees. See Tualatin Academy, A.T. Smith Papers, Mss. 8, oregon Historical society, Portiand, oregon. 
over 60\% of his time in 1841-42 establishing his farm. By the next year, 1842-43, his allocation of time between farmwork and community affairs began to equalize. In the year 1843-44, and 1844-45, it was almost equal. It was in 1845-46 that his division of activity began to diverge again, with farm work taking on greater and greater shares of his time until his financial success allowed him to retire in the early 1850 s.

Several points can be inferred from such a pattern. Smith, like all settlers, had to focus primarily on the hard work it took to establish his farm. It was the common lot of all the early settlers on the Tualatin Plains.

other settlers spoke of the early difficulties in establishing themselves in their later recollections. Peter Burnett, for example, recalled that

we were a small, thinly settled community, poor and isolated from the civilized world. . . For the first two years after our arrival the great difficulty was to procure provisions. 22

Burnett went on to discuss the impact of the succeeding waves of immigrants on life on the Tualatin Plains. Each wave created more and more demands on the food supply. The relative destitution of the newer immigrants along with the increases to the population combined to throw the Tualatin Plains communities in on themselves. The communities, by

129 peter H. Burnett, "Recollections and opinions of an old Pioneer," 168-169. See also J.I. Meek's account of the first year in Frances Fuller victor, The River of the west (Hartford, Conn.: Columbian Book Co., 1870), 287. 
necessity, had to assist the newcomers out of a common decency and hospitality that were an integral part of frontier life. ${ }^{30}$ As a result, the settlers who arrived between 1840 and 1850 focused on establishing a community rather than solely pursuing the development of their own economic well-being.

On the frontier, moreover, cooperative community was essential to the survival of all. That reality bred a sense of obligation to one's fellow immigrants even though meeting that obligation was not always happily borne, if Burnett is any example.

The old settlers had necessarily to throw open their doors to the new immigrants, and entertain them free of charge. Our families were often overworked in waiting upon others, and our provisions vanished before the keen appetites of our new guests. They bred famine wherever they went. ${ }^{131}$

The establishment of community during the first decade of settlement was therefore perhaps more an obligatory effort rather than one of total selflessness. For example, A.T. Smith's activities between the years 1842-43 and 1844-45 were such that he devoted almost equal amounts of time to community affairs as he did to his own farm. As one of the earliest persistent settlers, and because of his role in the West Tualatin Plains Congregational church, he was a man of

\footnotetext{
130 Burnett, "Recollections and Opinions of an old Pioneer," 169 .

131Burnett, "Recollections and opinions of an old Pioneer," 169 .
} 
social prominence, a man of considerable note. He was obliged by his status to take a role in actively assisting with the establishment of the community.

By plotting the names mentioned in smith's diary according to their relative proximity to his claim at west Tualatin plains and counting the number of times they are mentioned, an almost predictable pattern emerges. Smith's diary reveals the relnforcing effects of clustering on social and business networks and provides insight into the formation of neighborhood communities.

Smith had dealings with settlers from both west and East Tualatin Plains throughout the decade. Between the years 1841 and 1846, he records less and less contact with settlers at East Tualatin Plains, while recording an ever increasing number of contacts within his own neighborhood at west Tualatin Plains.132 By the late 1840s, west Tualatin Plains had evolved into a sufficiently populated community that Smith's contacts with East Tualatin Plains diminished. The increasing population base on the Tualatin Plains as a whole provided Smith with a greater range of social and business contacts after 1846. However, even with this

132 many of the names smith mentions in relation to the community of West Tualatin Plains appear not to have established claims. Some are clearly identified as laborers. Others may have been settlers passing through on their way elsewhere. Smith's diary does show that there was a traffic through the Tualatin Plains that did not settle there, for whatever reason. It supports the discussion above regarding the comparative differences between the 1845 and 1850 census. 
increase, Smith's contacts with East Tualatin Plains remained Iimited.

Out of 20 East Tualatin Plains household names mentioned in his diary between 1847 and 1853,7 are mentioned only once, 3 are mentioned twice, and five are mentioned three times. Smith had regular contact with only 4 East Tualatin Plains households on the average of once a year or less. J.s. Griffin, the Congregational minister residing at East Tualatin Plains, is the only resident of that neighborhood with whom smith had anything approaching the frequency of contact he exhibited towards his west Tualatin Plains neighbors.

If the establishment of community on the frontier obliged everyone to assist one another, even at cost of their own economic well-being, neighborhood clustering would appear to have circumscribed that obligation somewhat. Charity begins at home, or in this case, in one's own neighborhood.

During the year 1846-47, Smith's attention to his farm increased dramatically, while his social activities declined accordingly. Throughout 1848 and 1849 he devoted over three-quarters of his time to farm-related activities. only after 1850 , as Smith began to lease out portions of his claim and enter into semi-retirement did his allocation of time begin to approach that of the period between 1842 and 1846 when the settlement community on the Tualatin plains 
was being established. An explanation of the increase in farm activity might be found in a combination of factors. Smith's neighborhood had grown sufflclently to particlpate in the increase in economic opportunities that were the result of the growing local population and expanding trade and transportation faclities. The new markets of the California gold fields also provided new opportunities for economic gain for those with established, producing farms. ${ }^{133}$

Smith's interaction with other persistent landed settlers of west and East Tualatin Plains would indicate that his use of time was not atypical. None of smith's activities were exclusive, but involved the active participation of each person mentioned. The primary variation in the life of the community would be chronological. The later arrivals, those coming after the Tualatin plains had been substantially settled (1847-48), no doubt had less need of devoting energies towards the establishment of the community. On the other hand, they probably devoted a good deal of time to fitting into the community already in place.

1330wen, The willamette Valley, 76. 


\section{CHAPTER VI}

\section{THE ECONOMY OF EAST TUALATIN PLAINS}

The community that evolved at East Tualatin Plains between 1840 and 1850 was one bound together socially out of economic necessity as much as cultural homogeneity. The rigors of establishing community on the frontier precluded selfishness as much as they promoted rugged individualism. The community of East Tualatin Plains was composed of those who prized a high degree of economic individualism based on a cooperative spirit that supported such individualism. subsistence farming and a barter economy were the foundations of the East Tualatin Plains community during its founding decade.

East Tualatin Plains was an agricultural community. Farming was the basis of its economy and therefore its society. The nature of the agricultural economy of the Northern willamette valley and East Tualatin Plains in particular affected the community's relationship to the rise of the town of Hillsboro.

By the early nineteenth century, farming had evolved into a business. It was becoming less and less the integrated way of life it had been in the previous century. The evolution of the market economy in New England fostered 
an immigration to the mid-west, where pre-market agricultural society could survive and acclimate itself to changes in the economy at a slower pace. A lack of adequate transportation created a self-sufficient domestic economy. Farm self-sufflciency depended on intense social intercourse, based on the small village. ${ }^{134}$

Until the $1860 \mathrm{~s}$, the means of production restricted mid-western farmers in large measure to self-sufficiency. Hand technology limited the development of acreage. Before the 1850s, most mid-western farms were limited to 40 - 50 acres under cultivation. ${ }^{23}$ The settlers who established claims at East Tualatin plains came from the self-sufficient agricultural traditions of the mid-west. Most managed to develop less than 25 to 50 acres of land within their first year or two. Most of the early effort was cooperative, in that development of land for cultivation, as well as harvesting, usually involved the assistance of neighbors, extended family or even hired laborers. 130

The bulk of the farming settlers at East Tualatin Plains by 1850 came from the western frontier, as has been

$$
\begin{aligned}
& \text { 134Faragher, Men and Women on the Oregon Tra1l, } 41 . \\
& \text { 135Faragher, Men and Women on the Oregon Trail, 41-44. } \\
& \text { 136Benson, "Aloha's Donation Land Claims,"; Bowen, The }
\end{aligned}
$$
Willamette Valley, 73; see also General Land office survey maps, 1851-52, T1N,R2W, T1N, R3W, T1S, R2W, T1S,R3W, which show amounts of acreage under cultivation versus size of claims. Only the earliest claims, 1841 to 1844 , have substantial areas under cultivation by 1851 . 
shown. Much of the early agricultural development of East Tualatin plains therefore reflected the farms of the midwest. For example, a typical farmstead on the Illinois frontier of the 1830 s consisted of approximately 60 cleared acres, producing ca. 1,000 bushels of corn, 100-200 bushels of wheat and oats, a small home-use garden, all surrounded with a worm-style fence. ${ }^{13}$ The prevailing attitudes generated by such frontier farming were based on getting by, not on market-economy production. Hunting was seen as far more necessary than agriculture in sustaining life. Even after ten years, subsistence farming on the Illinois frontier had not changed appreciably. An average farm in the 1840 s consisted of approximately 80 acres, with ca. 50 to 60 acres under cultivation, producing 1,100 bushels of corn, 150 bushels of oats, 50 of wheat, with 40 to 60 hogs, 12 cattle, sheep and poultry, vegetables, flax and root crops. ${ }^{338}$

On the oregon frontier this pattern of subsistence farming was repeated. The 1850 agricultural census indicated that most farmers had improved less than 80 acres, less than one quarter to one eighth of their claim depending on size. The farmers, limited in technology and hindered with a multiplicity of tasks, were restricted to a subsistence level of agriculture with its corresponding

\footnotetext{
137 Faragher, Sugar Creek, 71.

138Faragher, Sugar Creek, 97-98.
} 
limitations in land development.130

Despite the limitations of subsistence agriculture, the opportunities of the new frontier were such that the early arrivals could not help but succeed provided they persisted. As early as 1840 , Lt. Charles wilkes was impressed with the economic well-being in the oregon country as compared to the United states.

In comparison to our own country, I should say that the labor required in this territory for subsistence and to acquire wealth is in proportion of 1 to 3 , or in other words, a man must work through the year 3 times as long in the United States to gain like compensation."1*0

The quality of the land and the climate combined to produce surpluses of the main cash crop, wheat. Wilkes spoke of the capacity of the willamette valley to produce bountiful crops of this commodity.

The wheat of this valley yields 35 to 40 bushels for one sown, or 20 to 30 bushels to the acre, its quality is superior to that grown in the united states and its weight near 4 pounds to the bushel heavier. The above is the yield of new land, but it is believed that it will greatly exceed this after the 3 rd crop, when the land has been broken up and tilled.141

The Tualatin Plains was less specialized with regard to wheat production. For example, it produced only 30,000 bushels as compared to 60,000 bushels in Champoeg county to

1390owen, The willamette Valley, 73.

140Lt. Charles wilkes, "Report on the Territory of oregon, 1838-1842," Oregon Historical Quarterly, 12(1911), 285. $1842, " 285$.

14'Wilkes, "Report on the Territory of Oregon, 1838- 
the south in 1847, when much of Twality county's land was already settled and cleared. ${ }^{142}$ In the Tualatin Valley, cultivated crops and livestock played equal roles in supporting the community. Proximity to the urban markets of the willamette caused the farmers of the Tualatin valley to direct slightly more attention towards market gardens, but overall, little preference was shown for any particular item. $1 * 3$

The agricultural economy imported to the Tualatin Valley from the earlier western frontiers included barter as the means of exchange. Barter was the standard way of business before the late 1840 s. Most crops were too bulky to transport, due to bad roads and high costs of freight. 14 Barter was so central to the economy of oregon in the mid1840 s that the Provisional Government established wheat along with treasury drafts and approved orders on solvent merchants - as lawful tender.14s The rate of exchange was fixed at $\$ 1.00$ per bushel.146

Barter retarded the economic development of the region by virtue of the insularity of the currency. Subsistence agriculture inherently insured against a rapidly developing

1427 January, 1847, oregon spectator.

1.3Bowen, The Willamette Valley, 94.

14 Faragher, Sugar creek, 103.

2.5ilbert, Trade and Currency in Early oregon, 47.

146Bowen, The Willamette Valley, 68 . 
economy. ${ }^{147}$ It was not until the late $1840 \mathrm{~s}$, with greater immigration and the Gold Rush that the economic isolation enforced by a barter economy began to wane. By that time subsistence agriculture had been in place for almost a decade, and would have a lasting effect on the shape of communities such as East Tualatin Plains. Dominated by a preponderance of subsistence-oriented settlers, it was less likely to be in the forefront of the evolving economy.

Another factor that contributed to the retention of old customs was the dominance of the Hudson's Bay Company in the area. The Hudson's Bay Company's presence in the oregon country prior to significant American immigration facilitated the establishment of the agricultural economy once large scale settlement got under way. The Hudson's Bay Company assisted the early settlers with loans of seed and equipment. As early as 1844 , some 4,000 settlers were indebted to the company to the tune of 100,000 dollars. In addition, the Hudson's Bay company controlled the trade market to the point of dominance, at least until 1848.140

East Tualatin Plains was not immune to the influence of the Hudson's Bay Company. Early settlers were "encouraged" by John McLoughlin to settle on the Tualatin Plains in order to facilitate company policies. ${ }^{49}$ once settled, farmers

14 7 Gibert, Trade and Currency in Early oregon, 57. 140ilbert, Trade and Currency in Early Oregon, 38-45. 149 Bowen, The willamette Valley, 12. 
such as Joe Meek were forced to do business with the Company at Oregon City due to the absence of other mills in the Tualatin valley. It was a four to six day effort to go to oregon city and back to grind wheat. ${ }^{3} 30$ The first mill in the Tualatin Valley was Joseph Gale's, established at Gale's Creek, west of West Tualatin Plains, ca.1844-45. East Tualatin Plains was not served by a mill until Henry Davis built his in 1848 on Dalry Creek. ${ }^{151}$ Even then such mills were probably run in the tradition of the subsistence agriculture that the western American settlers established on the plains in the 1840s. The milling operations of such communities did not pay, as they were built simply to accommodate the community.152

Even the more prosperous settlers on the Tualatin Plains were indebted to the Hudson's Bay Company. A.T. Smith had borrowed cattle from the company during the initial years of establishing his claim and by 1844 the Company was dunning him for their return.133 The company's influence even reached into the plains on a civil law basis. In 1844 James Douglas, a Company agent at Fort Vancouver,

1sovictor, The River of the west, 340 .

131Tozier papers, Mss. 1, Box C, file 6-7, washington county Museum, Washington county, oregon.

132 Faragher, Sugar creek, 68.

1s3letter from John McLoughlin, 15 May, 1844, A.T. Smith Personal Papers, Mss.8, Oregon Historical Society, Portland, oregon. 
ordered Thomas smith to return a misapproprlated mare to A.T. Smith and negotiate a settlement of the matter.1s* The relative ease of achieving agricultural success on the early oregon frontier proved to be as much a factor in undermining the dominance of the Hudson's Bay Company as it was in mitigating the negative aspects of subsistence farming. Within a few years of settlement, the farmers of East Tualatin plains were beginning to experience a level of prosperity that focused their attentions and aspirations on more than a subsistence living. By 1845 , even such nontraditional farmers as mountain man Joseph Meek could foresee his clain as the basis of wealth in the future. Meek also acknowledges the influence of the New England missionaries at East Tualatin Plains when he attributes its prosperity to the temperance of the community.iss

By 1846-47, agricultural production in the northern Willamette Valley was so great that produce could not be exported fast enough through the monopolized facilities then in place. Huge surpluses built up. ${ }^{156}$ It was the farmers of the Tualatin Plains who attempted to find a solution to the problems caused by their increasing agricultural

134letter from James Douglas, 8 May, 1844, Personal Papers, A.T. Smith, Mss. 8, Oregon Historical Society. Portland, Oregon.

15svictor, The River of the west, 367. See also Tobie, No Man Like Joe, 124. Meek provides a detailed accounting of his prosperity as a farmer in 1845 .

1s6Johansen, "The Land Base of Oregon's Economy," 3. 
productivity versus Hudson's Bay Company control. In 1846 and 1847, East Tualatin Plains men J.S. Griffin and Joseph Meek led farmers' meetings at the Methodist meeting house on the constable claim. The meetings agitated against merchant and shipper monopolies, that is, the Hudson's Bay Company and the American mission merchants. 157 The movement failed, for the same reasons such efforts falled on other frontiers. It lacked the very elements of the system it was opposing: capital, organization, a knowledge of business and the improvement of markets. 130

The anti-monopoly efforts of the Tualatin Plains farmers failed, in part, because of events outside their control. The discovery of gold in california created a market and nullified the surpluses of the early 1840s, consuming all that the willamette valley could produce. 139 By December of 1848 , flour had jumped from five dollars and fifty cents a barrel to twenty-five dollars a barrel in san Erancisco. Merchants who held wheat reserves got rich, but by 1849 willamette valley farmers were getting two dollars a bushel in lieu of the sixty-two cents a bushel of previous years. 100

1377 January, 1847, Oregon Spectator; 4 March, 1847, oregon spectator.

1seArthur L. Throckmorton, Oregon Argonauts. Merchant Adventurers on the oregon Frontier (Portland, or.: Oregon Historical society, 1961), 60 .

$139 \mathrm{Gilbert}$, Trade and Currency in Early oregon, 73.

160Throckmorton, oregon Argonauts, 94-95. 
By 1850 , the agricultural prosperity of the willamette Valley was at its peak. Some of the farmers of East Tualatin Plains were gradually forced out of subsistence level farming by the productivity of their land and the increased profits generated by $1 t .^{161}$

The economic impetus of the california gold rush era was not of sufficient duration to catapult the Northern willamette valley into the throes of a full market economy. one factor that can be used to measure the changes in the subsistence economy of East Tualatin Plains is the use of hired labor. An index is provided by the Illinois frontier. By the 1850s, the commercial era there had begun and hired labor was a necessity. For example, the average farmer in one Illinois community, sugar creek, had 2 hired laborers. As the original settlers grew more prosperous, tenant farming became another feature of commercialized agriculture. ${ }^{162}$ The era was characterized by changes in class relations - tenants versus owners - and increasing inequities in the distribution of property and advancing commercialism. ${ }^{163}$

During the early stages of a frontier, with free land and bountiful production, few men worked for wages. Labor

161 Johansen, "The Land Base of Oregon's Economy," 7 . With a few exceptions between 1851 and 1858 the economy of the willamette valley remained at the 1850 level until 1873 .

$$
\begin{aligned}
& \text { 162Faragher, Sugar Creek, } 187 . \\
& 163 \text { Earagher, Sugar Creek, } 225 .
\end{aligned}
$$


was therefore scarce and expensive. As a result, few farmers could afford hired hands, and families had to be relied on for labor.16* By 1850, labor prices in the Northern willamette valley had not declined to a point where everyone could afford hired hands. Or, put another way, the economic prosperity occasioned by the Gold Rush was not sufficient in volume or distribution to put hired labor within reach of everyone. In 1850, skilled labor was valued at 8-10 dollars a day, and unskilled at 4-5.16s

An analysis of the occupations of the landed households on the East Tualatin Plains in order to identify which farms employed laborers provides some sense of its economic wellbeing. Thirty-three non-landed residents of East Tualatin Plains listed their occupations as laborer in the 1850 census.166 of these, 32 were single males, the bulk - 20 of which were in the 20-30 year old age bracket. Two landed households employed 3 laborers each, accounting for 6 . Six landed households employed 2 laborers each, accounting for another 12. Thus, only 8 landed households out of 94 accounted for $54 \%$ of the hired labor at East Tualatin Plains in 1850 .

In addition, there are 44 other males over the age of

${ }^{264}$ Faragher, Sugar Creek, 99.

165 Johansen, "The Land Base of Oregon's Economy," 4.

260 the term non-landed here refers to individuals who did not have established land claims. They were listed as members of landed households in the census. 
18 with no occupation listed in the 1850 census. Twentyfour of these are etther sons of landed heads of households, or single heads of households with land claims but listing no occupation. The remaining 20 men may well have been laborers, or extended family members serving as laborers. Seven of these additional potential laborers worked for 2 landed households, 3 for one, and 4 for another. The balance, 13, worked as the sole laborer for landed households. If these additional men are included in, the distribution remains about the same as with the specifically identified laborers. Twenty-five of 53 , or about $47 \%$ worked for only 9 landed households. More significantly, one landed household with three laborers, that of william Chambers, gained three more from the second group of single young men listing no occupation. One other landed household, that of William Bennett, entered the list of large employers with the second group of young men, having had 4 in his household.

Thus, at East Tualatin Plains as of 1850 , only 3 landed households employed a number of laborers: Chambers(6), Bennett (4), and Pomeroy (3). Six other landed households employed 2 each. Of the three largest employers, 2 were relatively late arrivals. Chambers arrived in 1846, Bennett in 1849. Pomeroy, who employed the least laborers of the three, arrived in 1843. Nine households out of 94 can therefore be assumed to have had a greater degree of 
economic well-being than their nelghbors at East Tualatin Plains. The gold rush-insplred economic boom posstbly did not push a significant percentage of East Tualatin Plain's settlers into a level of farming that could be considered as commercial.

Perhaps the main economic limitation of the East Tualatin Plains economy was its distance from the centers of population and trade in the Northern willamette valley. On an undeveloped frontier, logistics are based on the path of least resistance. In the Northern willamette valley, that path was the river itself and 1 ts major tributaries. Major commercial centers developed along the willamette, principally Champoeg and oregon City during the early phase of settlement (1834-1846).

The settlement of the Tualatin Plains was encouraged by the Hudson's Bay Company in order to isolate as much as possible the unwanted American settlement from the Company's commercial operations. The Tualatin valley was isolated from the main willamette valley by mountains to the south, east and north. The only access was by crude trails, or through the break in Tualatin Mountains made by its river, through the Tonquin scablands.

The Tualatin River was a poor highway. It was prone to flooding, and frequently clogged with driftwood as a result. The floor of the Tualatin valley was cut up with a number of creeks, as well as swampy areas due to the soll types and 
high water table. Either river or land travel was very difficult as a result of these natural imitations. Alvin Thompson Smith relates in his diary that trips to East Tualatin Plains from west Tualatin Plains - a distance of about 6 miles - took a day to accomplish, while trips to oregon City at the willamette Falls took 2-3 days. Smith mentions a meeting in December of 1842 of Tualatin Plains settlers to discuss the construction of a road from the Plains to the willamette River. ${ }^{167}$

The settlers on the Tualatin Plains were eager to win their independence from the dominance of the Hudson's Bay Company and the Methodist Mission merchants. One of the keys to that independence was improved transportation. In 1844, Peter Burnett and Morton Mccarver, both of East Tualatin Plains, founded the speculative town of Linnton on the Willamette River, in an effort to break the Hudson's Bay Company monopoly on shipping. Joseph Meek and other Tualatin Plains settlers invested in the town. ${ }^{168}$ Linnton was to be a port for Tualatin Plains produce. The proprietors opened a road, but it was too difficult to haul produce in volume. Linnton's proprietors lacked the

167A.T. Smith, Diary, 1840-1853, Mss. 8, Oregon Historical Society, Portland, Oregon.

168 Tobie, No Man Like Joe, 111-112. 
resources to improve the road. The town failed.160

Another wagon road between East Tualatin Plains and the Willamette, at what was to become the speculative town of St. Helens, was constructed in 1847-1848.270

In 1848, transportation had become an issue for the new Territorial legislature. On 8 May, 1848, it began a comprehensive road bullding program. The washington county court was authorized to lay out a territorial road from Portland - then located in washington county - to the mouth of Mary's River to the south. In addition, road districts were established on the same day. East Tualatin plains was of sufficient importance as a community to warrant its own road district, and was of sufficient size and economic stability to warrant supporting its own road construction. Caleb Wilkins was appointed supervisor for the East Tualatin Plains district. On 9 May 1848, the County court ordered the district supervisors to institute a road construction program based on citizen labor in lieu of direct taxation. ${ }^{1>1}$

Warrant or not, it appears that little was done towards actually laying out or constructing any local roads in, around or from East Tualatin Plains for several years.

169Eugene B. Snyder, Early Portland. Stumptown Triumphant. Rival Towns on The willamette, (Portland, ore.: Binford and Mort, 1970), 127-129.

$1>0$ Snyder, Early Portland, 147.

171 Inventory of the county Archives of oregon, No.34, 124. 
Until 1855, substantial road construction was left to private efforts by the Territorial Government.172 The best example of this in the Tualatin Valley was the PortlandTualatin Valley Plank Road, which was opened in the fall of 1849. This road was a joint private venture capitalized by Portland businessmen and Tualatin Plains farmers. Both groups wanted a shorter route between the Tualatin plains and the willamette River markets. The farmers wanted greater ease of transport and greater flexibility in marketing their produce. The businessmen wanted to secure primacy for their new town of Portland as the export center for Tualatin valley produce. However, private enterprise was not up to the task. The road was poorly constructed over difficult terrain, and was virtually impassable during the rainy season. 173

open competition for the produce of the Tualatin plains is evidenced by several articles in the oregon spectator between 1851 and 1853 , encouraging the improvement and use of the Tualatin River for commercial navigation. In 1851 an editorial claimed improving the river would cut days off the farmer's hauling time over the plank road.17 That same

1720 scar osburn winther, The old oregon country. A $\frac{\text { History of Frontier Trade, Transportation, and Travel, }}{\text { (stanford, Cal.: Stanford University Press, 1950), } 124 .}$

173 See Balfour, "The Portland-Tualatin Valley Plank Road," for a detailed discussion of this road project.

170 Oregon spectator, 18 November 1851. 
year a rather pointed letter appeared in the oregon spectator from a Tuality Plain settler chastising oregon City merchants and their elected representatives for their sloth in not spending public money to improve the Tualatin River. The Tualatin Plains view was that oregon City needed them more than the Tualatin Plains needed oregon City. oregon City ought to champion the improvement of the Tualatin River or risk losing out to portland for its business.170 In 1852 the oregon spectator reported on a mass meeting at the washington county court house regarding commercial navigation of the Tualatin. A letter in the same issue discussed the prospect of a $60^{\prime} \times 12^{\prime}$ ' steamboat in the Tualatin to compete with the plank road if the river were cleaned out. ${ }^{1>7}$ It would seem that there was increasing interest on the part of oregon city to secure Tualatin Plains produce by way of the Tualatin River and thereby deprive portland of it. The Tualatin plains farmers were not interested in underwriting such a goal on their own.

The farmers of the Tualatin Plains had a clear sense of the limitations to their economic well-being due to a poor transportation system. Their frustration, however, was apparently insufficient to force the issue. It may well be that within the East Tualatin Plains community there were

\footnotetext{
176 oregon spectator, 2 December 1851. 17 oregon specator, 2 March 1852.
} 
not enough commercially viable farms to support a greater drive for Improvements to the transportation system. Hence the slang between editors and farmers, both looking to public expenditures for the solution. Such an approach is in keeping with the attitudes of settlers from the western United states, who frequently looked to state and national government for collective solutions to the problems of frontier development. ${ }^{17}$

The economy of East Tualatin Plains matured during the settlement decade of 1840-1850, but it did so within the limiting framework of the settler's traditional subsistence farming. The community filled with farmers from the Mississippi and Ohio River valleys. More crops were planted and harvested. However, a paucity of markets, a barter economy and poor transportation were both features and causal factors of the persistence of subsistence farming during the settlement decade. Outside forces were required to boost the economy to commercial levels. The ingrained nature of subsistence farming at East Tualatin Plains precluded the community actively seeking out and working with the outside forces necessary to change the economy. Inherent in East Tualatin Plain's limited economy were the mechanisms of its persistence. It is against the background of such a frontier farming community that the founding of

${ }^{17}$ W.T. Jackson, Wagon Roads West. A study of Federal Road surveys and construction in the Trans-Mississippi West. (New Haven, Conn.: Yale University Press, 1952). 
the town of Hillsboro must be viewed. 


\section{CHAPTER VII}

COUNTY SEAT AND PIONEER TOWN: HILLSBORO, 1850 - 1860

Hillsboro was created to serve as the seat of government for washington county. The location of the county seat at Hillsboro was due to the efforts of a very few men under the leadership of David Hill. As a community leader, Hill perceived a need for a county seat in order that the government might function more efficiently in serving the needs of the community. It is not known what Hill envisioned for his town beyond serving as a county seat. It is probably safe to say that neither Hill nor the surrounding community of East Tualatin Plains looked to Hillsboro as an eventual commercial center, capable of leading the economic development of the area. Hillsboro came into being because a center of government was needed in Washington county.

Government at the local level was not the answer to such developmental problems as transportation improvements. Local government created road districts, but the economic base was not sufficient to tax the community for actual construction. Even road maintenance was left to those who lived along the roadways to carry out. The role of local government in a subsistence-oriented agrarian community was 
fairly limited. Traditionally it consisted of a modest bureaucracy limited to a county sheriff, and the setting of prices at mills, ferries and taverns. Such further amenities as schools and road districts were citizen-based institutions, not government. 179

On the Tualatin plains, local government was composed of the officers elected from the community to carry out the functions described above. However, there were frequent, almost annual changes in office holders. The positions did not offer full-time employment, and no doubt the men who held office did so out of a sense of shared obligation rather than a desire for a career in politics. ${ }^{30}$

That there was a local government on the Tualatin plains at all is due to the active participation of its settlers in the formation of the Provisional Government between 1843 and 1845. Men such as David Hill and william Doughty were members of the first legislative committee of the Provisional Government. ${ }^{121}$ A court system was put in place in 1845 to administer the four districts of the government, Champooeg, Yamhill, Clackamas and Tualaty. The Tualaty District court met on the East Tualatin Plains in the meeting house located on the constable claim, in the

179 Faragher, Sugar creek, 137.

180 Inventory of the County Archives of oregon, No.34. washington County, Oregon, 14.

1'Carey, A General History of oregon, 332. 
center of the northeast prairie.3az The business of the courts was limited. In 1846 , the courts met only 2 days in four months. In 1851, a session of three weeks made the papers as an exceptional event in the Territory.10s

As the population increased throughout the 1840s, the business of the district court kept pace. East Tualatin Plains was a farming community with no fixed center, and the court was forced to convene where space could be had, such as the meeting house. The lack of a permanent meeting location for the district court apparently became a concern of at least one of East Tualatin Plain's earliest leading citizens, David Hill. Hill had been active in the formation of the Provisional Government. A native of connecticut, he was a New England settler who had broader civic and economic aspirations than some of his neighbors from the western states. He was a frontier variation of Earl Pomeroy's urban easterner, a man who carried to the frontier a desire to actively build a community and not just engage in subsistence farming.

Hill was not loath to promote his own neighborhood nor his own giaim. He styled his land claim as the town of columbus as early as $1846^{184}$. The Territorial Legislature

182Inventory of the County Archives of oregon, No.34. washington county, oregon, 14. The meeting holise on the constable claim is referred to as Methodist as well as presbyterian.

18319 February, 1846, Oregon Spectator; 11 November, 1851, Oregon Spectator. 
selected this location as the county seat in 1849 . We have no record of the county court's views on this action, but as its members were all neighbors, it is probable that Hill's intentions were at least known to the court. ${ }^{10 s}$

One reason to make that assumption is that Hill sold a 40 acre parcel of his claim and a log building located on it to the county court sometime during late 1849. The price of sale was 200 dollars. The court was to plat the parcel as the town of columbus, which was to serve as the county seat. The court was to sell lots in the town with all the proceeds to go into a county building fund. Hill's log building was to serve as the courthouse. ${ }^{186}$ Hill subsequently pursued a post office designation for the new town. Writing to samuel Thurston in January of 1850, he mentioned Columbus as the new county seat, and recommended Abraham sulgar, a young, single Philadelphia merchant who had a store at columbus, as the possible postmaster. ${ }^{37}$

1 ssetter from David Hill to samuel Thurston, 13 December, 1349, Letters, samuel R. Thurston Papers, Mss. 379, oregon Historical society, Portland, oregon. The name of Hill's would-be town is erequently mistakenly cited as Columbia, due to the handwriting in Hill's letter. Why Hill chose columbus as a name is not documented in the letter or anywhere else.

18s Inventory of the county Archives of oregon, No. 34 . washington County, oregon, 12-15.

187Letter to Samuel Thurston from David Hill, 6 January, 1850, Letters, Samuel R. Thurston Papers, Mss. 379, oregon Historical Society, Portland, oregon. Sulger apparently opened his store in December of 1849 or January of 1850. 7 February, 1850, Oregon spectator, ad for sulger's store in Columbus. 
Hill died in May of 1850. Local historians have credited the townspeople of columbus with having asked that the town be renamed in Hill's honour as Hillsborough.'o As the town consisted of sulgar's store and the log courthouse in 1850, it is unlikely that there were many townspeople to make such a request. It is more likely that Abraham sulgar, as postmaster, changed the name in honor of Hill's aspirations for a county seat on the East Tualatin plains. Sulgar may have viewed Hill's early political prominence and good name as an asset to a new town.

Hill's efforts to found a town as County seat may have been influenced indirectly by the impact of the california gold rush. The influx of gold in 1849 boosted the willamette Valley economy. Agriculture and business growth was stimulated, and many small villages and towns sprang up. 109 This was due to a large number of men from the willamette valley who went to california and returned during the winter months of 1848-49.190 while these men were among the first to arrive in california, those who remained behind often did much better financially because of the demands of the gold fields on oregon's agriculture. This would appear

19a.W. Moore, Mrs. and Joseph Lepschat, Mrs., "Early settlements of Washington County," Mss. 325, washington county Museum, Washington County, Oregon.

199arey, A General History of Oregon, 478; Robert $w$. Johannsen, Frontier Politics on the Eve of the Civil war, (seattle, wa.: University of washing Press, 1955), 6.

19oThrockmorton, oregon Argonauts, 88-89. 
to be the case for East Tualatin Plains. While it is estimated that as many as two-thirds of the men in the willamette valley went to the gold flelds in the fall of 1848, the number of men from East Tualatin Plains who went were far fewer.191

An analysis of the information regarding absence in the gold fields found in the abstracts of the Donation Land Claim records for East Tualatin Plains reveals that only two men went to the gold fields. Philip Harris, a carpenterfarmer from New Jersey, who later operated a ferry on the Tualatin River, and Richard white, an Englishman. Harris stayed one month, and white ten. West Tualatin Plains had four men who went to the gold fields, three of whom were New England or mid-Atlantic in origin. Only one westerner, a Kentuckian, went.

The Tualatin Plains -- east and west -- made only a token participation in the gold rush. Those who went were not the western subsistence-oriented farmers but those from regions more prone to entrepreneurial risks. It would appear that the vast bulk of East Tualatin Plains settlers were more intent on farming than prospecting for gold. Thus, how much of a factor the gold rush was in Hill's ambitions for his new town of columbus we do not know. From his comments to Representative Thurston, Hill may have been riding a wave of enthusiasm for growth and development

$191 \mathrm{Gilbert}$, Trade and Currency in Early oregon, 73-74. 
sparked by the gold rush, and wanted to insure that his community would share in that growth. Hillsboro's genesis appears to have been a combination of frontier civic pride and community need rather than outright speculation as was the case with such towns elsewhere. It was a speculative effort only to the extent that the government had to engage in real estate promotion in order to settle its debts with Hill.

Sometime prior to the platting of Hillsboro in March of 1850, Isaiah Kelsey donated rather than sold another 40 acres to the county court. Kelsey was the Kentucky member of the Hillsboro cluster. His reasons for the donation and its exact date are not recorded. The donation was made in an informal manner, as the court had to secure a proper instrument of conveyance from Kelsey in July of 1853.192 Local tradition has it that Kelsey's donation was for the purpose of providing land for a courthouse.193 It is more likely that Kelsey was moved by a spirit similar to Hill's, if less profit-oriented, and wanted to participate in the founding of the new town. A courthouse could have been built anywhere on Hill's original forty acre parcel. Kelsey's donation provided a balance of land to the new

192 Board of Commissioners Journals, Washington County, oregon, Vol. 2,5 July, 1853,35 .

193 Moore and Lepshat, "Early settlements of washington County," 4. The fact that the public square of the town was located in Kelsey's donation probably gave rise to the tradition that he donated the land for that purpose. 
town, in which a public square was incorporated into the center of an square eighty acre plat.

Abraham sulger, the mid-Atlantic merchant, was probably the leading force behind the speculative aspects of Hillsboro's founding. The plat of the town was filed on 1 March 1850 with the county Court. 19.4 within days of the plat being filed, sulger's advertisement in the oregon spectator revealed his interest in the new town. The name "Columbus" had been changed to Hillsboro, and the ad stated that a plan of the town with lots for sale was on view at his store. ${ }^{19 s}$ In May 1850, sulger's advertisement was still promoting town lots in Hillsboro, and also mentioned that the town was soon to be served by a rail line from pacific City to Lafayette. ${ }^{190}$ No record exists of such a proposed line. It is likely that sulger was using the mention of a possible rall line to promote sales in the town.

It may be that sulger was repeating the speculative rumors of the day with the intent of promoting growth in Hillsboro. By October of 1850 Sulger's advertisement had changed yet again, reflecting similar promotional overtones. It utilized the name washington county in lieu of Tualatin Plains, acknowledging Hillsboro's status as the new county

1oeplat of Hillsboro, 1 March, 1850, washington county Surveyor's office, Hillsboro, oregon.

1937 March, 1850, Oregon Spectator

19516 May, 1850, Oregon Spectator 
seat. It solicited a blacksmith with his tools for a shop in the county seat. It utilized promotional rhetoric in connection with the promotion of town lots. "The advantages of locating in this healthy spot are too well known."197 sulger may not have been the only promoter of Hillsboro but, as the only advertising merchant in town, he was the most visible. That the county court would use his store as a real estate marketing device was in keeping with the informal nature of the East Tualatin plains community.

The first actual sales of town lots occurred at auction on 5 March, 1850. The auction produced limited sales, but it revealed much about who was behind the new town. The plat contained twenty-nine blocks of eight lots each, ninety-nine feet by one hundred ninety-eight feet. There was also one block dedicated as a public square. At the March auction, only 12 lots were sold out of one hundred twelve available.190 From the sales, a profile emerges of who invested in Hillsboro. Merchant Abraham Sulger bought three lots, Dr. Wilcox bought two, and neighboring farmer Moore bought one. The amount of land purchased suggests the relative interest of the local settlement cluster in the

19717 October, 1850, Oregon spectator. The role that health played in attracting settlers to the Tualatin valley is reflected in this kind of statement. The very first "marketing" of Hillsboro was in terms of quality of life and not financial gain.

198 Not all the blocks in the plat had numbered lots in 1850, hence the lower number of available lots as measured against the number of blocks. 
town's founding. It is not surprising that sulger purchased more land than Moore did.190

The balance of the purchases were made by prominent men in the Tualatin plains community. A.T. Smith bought two lots, William Geiger, Sr, and Jr. each bought one lot, as did George Ebberts and David Lenox. It may be that these men, who were outside the Hillsboro cluster, purchased lots for speculative gain as well as to contribute to the establishment of the county seat. Such motivations would be in keeping with Hill's original interest in the town and the nature of the Tualatin Plains settlement community. 200

The location of the initial sales also illustrates the nature of Hillsboro. The purchased lots were primarily located to the west and east of the public square, in the style of the New England town common. Forest Grove, located six miles to the west of Hillsboro, would later develop in a

199 Deed Books, Washington County, Oregon, 1849-1882, Books $B, C, D, \& E$.

$200^{\circ}$ oth David Lenox and A.T. Smith served as judges on the county Court during 1851-52. William Geiger served as Clerk during the same period. Their respective public service ambitions probably also influenced their interest in property in Hillsboro. Lepshat and Moore, "Early settlements in Washington County," 6. A.T. Smith in particular was not above speculation. In December of 1850, he bought a share in the steamboat "Goldhunter" for one thousand dollars, paying three hundred thirty-five dollars down at an investment meeting in Hillsboro. A.T. Smith Diary, 18 December, 1850, A.T. Smith Papers, Mss. 8, Oregon Historical society, Portland, oregon. 
similar pattern.201 The grouping of the initial sales around the public square indicates the lack of a dedicated main street as a center of trade. Most of the land was sold to prominent farmers, who never established businesses or residences on their lots. Only Merchant sulger and Dr. Wilcox were townsmen.

Barbara Bailey, in her study of eastern oregon, has found that pioneer oregon towns elsewhere had established merchants in place by the time of their platting. ${ }^{202}$ Main street played an important role in the development of pioneer towns. Bailey found that most towns in her study included a main street in their plat. Such streets were usually laid out to coincide with an existing road that ran through the town plat. The selection of a town's main street was central to town planning. Without a main street, there was no town. It was the essential ingredient, the center of trade. 203 Hillsboro's plat did not show a main street until 1860 , when the town was resurveyed. ${ }^{20}$

${ }^{201}$ History of Forest Grove, washington County Cultural Resource Survey and Inventory Project, 1984. Washington county Museum, washington County, oregon.

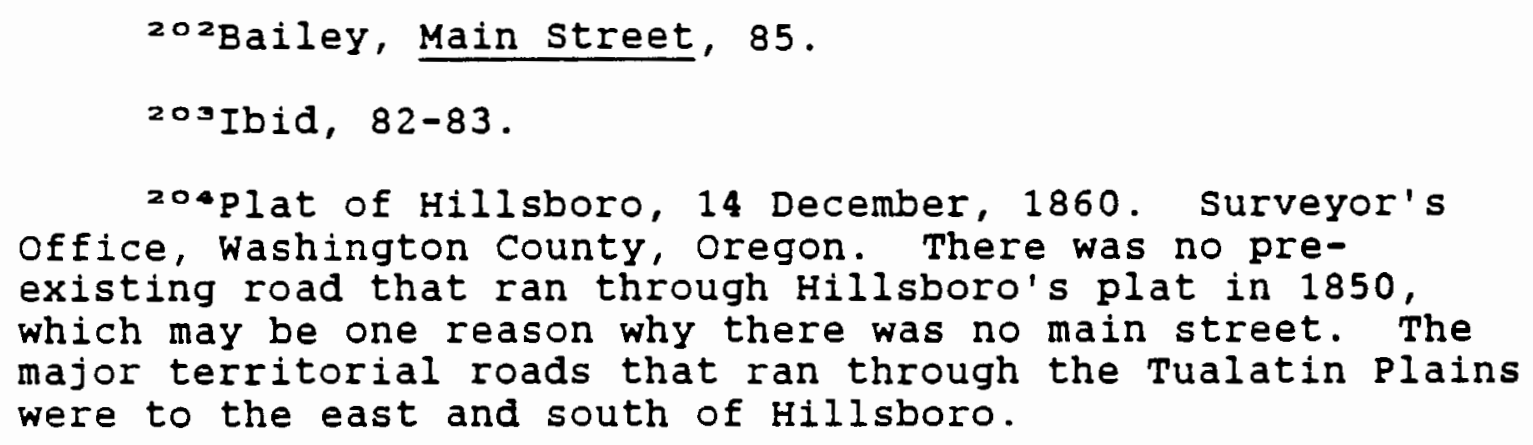
office, washington County, oregon. There was no preexisting road that ran through Hillsboro's plat in 1850, which may be one reason why there was no main street. The major territorial roads that ran through the Tualatin plains were to the east and south of Hillsboro. 
In pioneer towns with dedicated main streets, the prime commerclal lots sold quickly. The turnover in lots indexed the rise of the town. The values increased due to demand and the construction of buildings on the lots.20s After the first sales in March of 1850, few lots sold in Hillsboro for some time; between June 1850 and December 1859, only six additional lots were sold. The sale price remained the same as it had been at the first auction, approximately fifty dollars per lot. The price of lots remained between thirty and fifty dollars for over twenty years, even when property changed hands from one private owner to another. ${ }^{20 s}$

Some of the first purchasers apparently had difficulty even paying for their land. By December of 1852, the county court was forced to order the sheriff to collect on balances due on lots sold.207 It is likely that after the first blush of interest in Hillsboro that those who had invested initially lost interest and had other things to do with their money.

Hillsboro in $1850-51$ was probably not much to look at, despite its land sales. T.J. Dryer, in his "Birds-eye View

20sBailey, Main Street, 85.

206 Deed Books, 1849-1882, B.C.D. \& E, washington County, Oregon. Commissioner's Journals, Vol. 2, 1852 It would appear that many of the lots purchased in the first auction were not built upon by their owners, as they often were sold for the same price or lower in the $1860 \mathrm{~s}$ and $70 \mathrm{~s}$.

207 Commissioner's Journals, Vol. 2, 18. 
of oregon," described it as follows.

Hillsborough, the county seat of washington County, is yet a small town, situated 18 miles west of Portland, in the midst of one of the most beautiful agricultural regions we have ever seen, on what is called the Tualatin Plains.20

Dryer was being kind. The field survey notes for the Federal cadastral survey carried out in May, 1851 provide the earliest description of what the surveyor called the "village" of Hillsboro. It consisted of four structures, a log prison, a log court house and two other houses.200 In a later reference, the surveyor provides more specific identities and approximate relative locations for these structures. The description and locations provided by the surveyor indicate that all the structures were located on Hill's donated property and not Kelsey's, and that their location did not conform to any platted town street grid. 210 There is no mention of the town plat of Hillsboro in the survey notes, nor the properties purchased in March of 1850. Most of the Iand purchased at the 1850 auction came from Kelsey's donation and not Hill's. By May of 1851 at least, no one had rushed to make improvements on their newly

20819 December, 1850, Oregon spectator.

$209 \mathrm{Field}$ Survey Notes, Cadastral survey, General Land office, May, 1851, Vol. R-2, 18-20.

$210^{\circ}$ ield Survey Notes, Cadastral Survey, General Land Office, May, 1851, Vol. R-9, 197. The construction of the structures referred to in the field notes took place prior to the platting of the town, so it is not surprising that their locations do not conform. 
acquired property.

That Hillsboro failed to experience a rapid expansion in 1850-51 is not particularly surprising. Coupled with the nature of the East Tualatin Plains community and the somewhat limited purpose behind the town's platting, Hillsboro was not unique in stagnating after its establishment. Many of the towns founded in oregon during the flush of economic development founded on the california gold rush also failed to develop. 211

Even if Hillsboro was not, strictly speaking, a speculative town it still had its promoters. The key to its growth was transportation. The new towns platted during the early 1850 s were all oriented along rivers and aimed at transportation in order to achieve a primacy in shipping. 212 Hillsboro was not exactly located to take advantage of either river or land-based transportation, but its promoters did not balk at that. Merchant sulger had initially relied on a possible rail link for the new town in 1850. By 1852, sulger, along with two non-Hillsboro men, composed a committee of stock holders in the Portland and Valley Plank Road Company. Sulger apparently believed in the land route. 213

The river route was not without its advocates. A

$$
\begin{aligned}
& 211 \text { Bancroft, Vol. II, } 251 . \\
& 212 \text { Carey, History of oregon, 648-650. } \\
& 213 \text { Balfour, "The Portland and Valley Plank Road," } 4 \text {. }
\end{aligned}
$$


correspondent, going under the initials "MRB" regarded the plank road effort as a "humbug" and championed the Tualatin River in a letter to the oregon spectator. As in the 1840s, the problem with using the Tualatin was one of driftwood. If the Iiver could be cleared, according to "MRB", steamboat service was assured and would be a vast improvement over the crippling plank road.214

It was an argument that echoed similar ones from the 1840s. The 1852 correspondent was probably basing his case on the existence of the new town and the popular belief that it would make a difference in using the Tualatin River for commercial navigation. The Federal surveyor documented such opinion in his field notes: "It is proposed to improve the river up to this point (south of Hillsboro) for a small steamer that is being built near its mouth."21s

The low volume of land sales and related stagnation in hillsboro in the $1850 \mathrm{~s}$ may be due to the inability of either the community or the private sector to improve the town's links with the outside world. The primary purpose of the town had been to found a county seat and the resources were found to

2142 March, 1852, Oregon Spectator.

215Field Survey Notes, Cadastral survey, General Land office, May, 1851. Vol. R-9, 163. It is unknown as to who was constructing a steamer or proposing to put it into the Tualatin in 1851-52. The Tualatin River Transportation and Navigation Company was incorporated in 1856, and made efforts to open the river to navigation. The company was not successful in meeting that goal until 1866, when it put the steamers onward and Yamhill into service. Tualatin River Navigation study, $\overline{16-18}$. 
proceed with that limited goal. By July of 1852 , specifications for a two story cedar courthouse were published, and the building was in place by December of that year.216 In July of 1853, a jail was commissioned.217 The court met every two to three months for several days business. The limited nature of county government during this period precluded much business growth in the town beyond a blacksmith and a general store or two. The description of Hillsboro in 1859 by a traveler, Sara Lindsay, makes the point; she found it to be the poorest kind of apology for a village, noting that it was "...a very small place, containing about 12 houses, 3 or 4 stores, and courthouse and a blacksmith shop."220

Little else is known of the growth of early Hillsboro between 1853 and 1860. An analysis of the 1860 census confirms the image of a small, stagnant, county seat. There was some growth in population as well as businesses between

$$
\begin{aligned}
& 216 \text { Commissioner's Journals, Vol. 2, 1852. 6, } 17 \text {. } \\
& 217 \text { Commissioners Journal, Vol. 2, 1853. 35. The jail }
\end{aligned}
$$
was built in Block 18, several blocks away to the southeast of the public square and its courthouse. By the 1860 s this part of town would become residential, but the volume of growth necessary to push residential development that far from the public square was apparently not envisioned by the county government or anyone else in 1853. Growth may have been desired, but not anticipated.

22 Bourke and Debats, 27-28. 
1853 and 1860 , but not of a significant volume.219 By 1860 , the population of Hillsboro was approximately 64 people, comprising about 12 households. The town featured occupations typically found in a ploneer town: a lawyer, a doctor, a clerk, a bookkeeper, 3 merchants, 2 blacksmiths, 2 wagoners, 2 carpenters and a hotel keeper, as well as several laborers. The actual composition of the village indeed included the courthouse and jail, a blacksmith, at least 2 stores and a hotel. The doctor and lawyer probably operated out of their homes, as did the carpenters and laborers. There were probably only a dozen or so residences, accommodating a like number of families as identified above. Five of the households had one or more boarders, which accounts for the relatively large population for so few residences. 220

The actual location of many of the stores and residences in 1860 is unknown. Hillsboro's plat was resurveyed in 1860 , for the purposes of correcting some minor anomalies. A main street was identified on the new plat. However, since most of the privately owned lots in Hillsboro were located around the public square prior to the

219 It is difficult to locate individuals in the 1860 census specific to the town of Hillsboro, as no census precincts are listed. By comparing names and occupations found in the Deed Records, Commissioners Journals and the R.G. Dunn Company credit reports for Hillsboro, a rough estimate of population and businesses can be arrived at. 220 Census records, Washington County, oregon, 1860. 
naming of a Main street, some of the business activities came to be centered in part on Meridian street (later 2nd street) to the east of the square as much as they did on the new Main street. The rather haphazard development of businesses underscores Hillsboro's role as the county seat and secondarily a community- oriented service center. Hillsboro in 1860 was not a town deliberately pursuing a goal of commercial development.

The origins of the town's population in 1860 reveals the continuation of the microcosmic dichotomy between frontier townsmen and farmers that exhibited itself in the East Tualatin plains community as a whole at the outset of Hillsboro's founding. The merchants, professionals and many of the mechanics came from New England or mid-Atlantic states. The wheelwright and the hotel keeper were foreign born. The blacksmith, carpenters and laborers came from western states. The more commercial or professional one's occupation, the more likely one would be from the areas of the United states with longer urban traditions. Nine out of seventeen businessmen or professionals came from regions of the United states with such traditions. Hillsboro was not a speculative commercial venture in 1860 if. its population and business composition is any index. It was an evolving small pioneer town, the essential element being its status as a county seat.

At the end of the town's first decade of existence, 
little had been accomplished in terms of establishing anything resembling a commercial base. The town did not attract the kind of men who would push it from a sleepy county seat to boom town. This was so in large part because the surrounding community did not require nor want such a town in their midst. The kind of men who came to Hillsboro in the 1850 s and 1860 s understood East Tualatin Plains very well. They were the urban component of the Jeffersonian agrarian dream, the small townsmen of the rural frontier. 


\section{CHAPTER VIII}

HILLSBORO'S IIMITED AMBITIONS: 1860 - 1890

For the first ten years of its existence, Hilisboro was little more than a county seat located in the midst of an extremely small village. Few men of vision flocked to Hillsboro between 1850 and 1860 . The tone for Hillsboro's continued evolution was set by these first ten years. Hillsboro's tone was that of the small town businessmen who settled there. The leading citizens of Hillsboro were its professionals and businessmen. They were the kind of men who had an affinity for small towns like Hillsboro. Both the men and the town had limited growth potential, based on linited ambitions.

Hillsboro continued its slow development after 1860 . Between 1861-62, there was a burst of real estate activity in the town. Seventeen lots were purchased, mostly in the area of the public square. Presumably these lots were acquired for both commercial and residential purposes. Several of the new purchases were made by long-time established residents, the balance being bought by newcomers.221 This small burst of sales is hard to explain,

221 For example, Richard $E$. Wiley, the future grocer and saloon keeper, bought 2 lots from W.D. Hare, lawyer and merchant, who had acquired the lots he sold wiley from 
but it did not herald the beginning of a speculative era in the town's history. There were only two examples of relatively quick profit-taking out of seventeen sales.

only two of the purchases during this period were made by men who originally came from the surrounding East Tualatin plains settlement community. William Brown, a carpenter, was from New York. David Lenox, the Baptist minister, was also from New York. The temptations of town life were resisted by the western states settlers of East Tualatin Plains. Hillsboro's existence continued to depend upon the foundation established in the previous decade, a mixture of merchants and professionals from New England and the mid-Atlantic states and mechanics and laborers from the western states.

Until the end of the decade, little changed in the village. The flurry of lot sales between 1861-62 was followed by a hiatus similar to that of the 1850s. sales do not pick up again until 1869-70, and then the lot prices were much the same as before, thirty to fifty dollars each. The low price of lots and the lack of interest in Hillsboro they imply indicates that the town could not attract new residents or businesses in any volume. I.t is noteworthy that Hillsboro's business composition did not change appreciably for over twenty-five years. It kept the same

Abraham sulger. Such turnover in land ownership was unusual for Hillsboro if the Deed Records are any indication. Most lots went begging for between thirty to fifty dollars. 
inventory of one hotel, one blacksmith, and so on. some businesses did change hands, notably the hotel and general stores. Oddly enough, such businesses were sometimes run by local people who originated in the surrounding farming community and came to town to try their hand at a different way of Iife. Many failed. However, there did not seem to be any appreciable multiplication of various types of businesses in the $1860 \mathrm{~s}$, which also suggests limited growth. 222

People continued to arrive and set up shop in Hillsboro, but often they replaced a businessman who had moved on or had gone out of business. Hillsboro did experience some speculation in that regard, but of a limited type, that of lone hoteliers or merchants who tried their hand in Hillsboro, only to find success in business elusive. Those who stayed had to be patient and stay within the realm of limited horizons for their business.223

The sluggish growth of Hillsboro after the $1850 \mathrm{~s}$ and $60 \mathrm{~s}$ is related to the unsolved problem of transportation links with Portland. The plank road between portland and

222 R.G. Dunn \& Company Collection, washington county, oregon, Vol. 6. Baker Library, Harvard University Graduate School of Business Administration, Boston, Mass..

223 Riley cave is an example. He was one of the few businessmen of Hillsboro who came to the town from the surrounding settlement community of East Tualatin Plains. It took him three years of blacksmithing before he purchased a residential lot in town. Deed Records, 1849-1882. washington County, oregon. 
the Tualatin Plains was a fallure. It was planked only on the east side of the Tualatin Mountains to the summit, and was virtually impassable in the winter months. Improvements to the transportation system depended on private initiative. As a result, there was competition for the attention and money of those farmers at East Tualatin Plains who wanted improved links between their shipping point of Hillsboro and the Portland market. The split between those who wanted a land route and those who wanted a river route continued.

Abraham sulger had supported a planked road as early as 1852. The plank road solution had the consistent support of some of the Tualatin Plains farming community up to and even after the arrival of the railroad in Hillsboro in 1871.220 The debate over an improved land route revealed the level of commercial entrepreneurialism of the Tualatin Plains farmers. They wanted a better way of getting their produce to market, but they wanted someone else, preferable portland merchants, to pay for it. Nor were Hillsboro's merchants and businessmen able to underwrite an equal share of such a venture.22s Both the farmers and the townsmen apparently

224 Articles in The oregonian over a ten year period indicate that the plank road was the solution to Hillsboro's transportation problems that received the most interest in the public debate. 18 June, 1862, The oregonian; 4 March, 1867, The Oregonian; 11 December, 1867, The Oregonian; 19 February, 1872, The oregonian.

$$
225 \mathrm{An} \text { assessment of the pecuniary strength of }
$$
Hillsboro's merchants and businessmen in the $1860 \mathrm{~s}$ and $70 \mathrm{~s}$ based on the R.G. Dunn \& Company credit reports shows that the net worth of most was approximately 2.5 thousand dollars 
thought it was in Portland's interest to carry a greater share of the cost of improving the transportation links as they stood to gain more as the middlemen.

The river route was not developed however until the mid-1860s.23s Even then, it apparently was not viewed as the solution to the problem of transportation by the Hillsboro-East Tualatin Plains settlers. In 1868 The oregonian was still advocating navigation of the Tualatin River as the solution to the six month hiatus in agricultural produce shipping from the Tualatin valley caused by the bad roads.z27 For reasons unknown it appears that the merchants and farmers were still divided as to the best way to get their produce to market.

Hillsboro revealed its limited ambitions as well as means when the railroad made its appearance in the late 1860s. Joseph Gaston's Oregon Central Railroad was undercapitalized and threatened with a hostile takeover. Gaston

or less. Most had at best only a fair credit rating. Hillsboro was not a community of financially successful men prone to speculative investment. It can best be characterized as being composed of mostly honest men of good character, with limited business skills, ambitions and credit. R.G. Dunn \& Company Collection, Washington County, oregon, vol. 6 ..

$226 \mathrm{~A}$ steamboat served Hillsboro via a landing located immediately to the south of the town on the river by 1866 . Letter to A.T. Smith from J.S. Griffin, 16 November, 1866. A.T. Smith Personal Papers, Mss. 8. Oregon Historical Society, Portland, oregon.

227 James E. Farnell. Tualatin River Navigability Study (Salem, Or.: Division of state Lands, 1978) 19. 
had to appeal to the people of the communities he wished to serve with his railroad to rescue his venture with public funds. In essence, the governments of yamhill county and washington county were asked to levy a special tax to pay the interest on Gaston's oregon Central Railroad bonds so that he could complete his line. Washington county pledged to pay the interest on 50,000 dollars worth of stock, versus Yamhill county's pledge of 75,000 dollars. The level of support provided by the two counties reflected their respective tax bases. 220 More telling is the private investment response. Portlanders bought 50,000 dollars worth of stock, as compared to 25,000 purchased by Yamhill county citizens, and 20,000 purchased by washington county folk. 229

The railroad had come to town, but it was not received with open arms. Local land owners on the line directly to the south of Hillsboro refused to grant the railroad a subsidy of land for a station or make an addition containing such a station to the townsite. 230 The townsmen of Forest

228 In 1870, the assessed value of all property in washington County was 942,940 dollars; in Yamhill county the total assessed value of all property was $1,246,779$ dollars. By comparison, Multnomah County's total assessed value was $6,357,100$ dollars. Secretary of state, Biennial Report. 7 th Regular session, $1872,31$.

229 Joseph Gaston, "The Oregon Central Railroad," Oregon Historical Quarterly 3(December, 1902) 323.

23021 February, 1874, The Independent. The editorial did not name names, but wheelock simmons owned the land that the railroad right of way passed through. Simmons appears 
Grove exhibited a similar wariness towards being serviced by the railroad in such a manner. As a result, the railroad laid its lines to the south of the two towns, and founded the town of cornelius on their line between Hillsboro and Forest Grove. Cornelius was intended to challenge Hillsboro as the primary shipping point for Tualatin plains agricultural produce. Just for good measure, the railroad platted a public square in cornelius, in hopes of getting the county seat moved there as well.231

Cornelius ultimately proved to be less of a challenge to Hillsboro than was perhaps envisioned by the railroad. Thomas Cornelius had been enlisted by the railroad to serve on the Board of Directors as a local representative for the west side line. He took advantage of his inside position with the railroad by building a wheat warehouse in Cornelius. The railroad then refused to hire rail cars independently to valley farmers for shipping their wheat. Farmers were forced to ship their wheat through Cornelius' warehouse, with a charge of one dollar a ton. Cornelius' moropoly was deeply resented and many farmers refused to

to have been a sharp trader, in that he would not give something for nothing to the railroad, even though he and others eventually built a grain warehouse on the line. Such an attitude is not characteristic of an overt speculative adventurer but rather of a careful small town businessman of limited means and ambitions.

$231 \mathrm{History}$ of Cornelius, washington County Cultural Resource survey and Inventory Project, Phase II, Cities. (Washington County Museum, 1984). 
submit to his sharp practice. The Independent, a Hillsboro newspaper, took the side of the farmers and ralled against Cornelius' venture as unfair. Cornelius may have regard himself as an entrepreneur, but his neighbors regard him as a part of a monopolistic cabal.232

The farmers resolved to find an alternative way of getting their wheat to market, and the townsmen of Hillsboro supported them. One of its leading citizens, W.D. Hare, advocated the formation of yet another plank road company in 1871.233 Within days of the meeting at which Hare spoke, The oregonian was urging its readers not to be misled, that the plank road could not compete with the railroad.23. such outside opinion did not carry as much weight in Hillsboro as Hare's opinions did. Hare had served as county Clerk in the 1860s. Many of the leading men of the town had served in

\section{4 september, 1874 . The Independent. \\ 23319 Eebruary, 1872, The oregonian. East Tualatin} Plains farmers took revenge on the railroad for not building a station at Hillsboro by resolving to haul their wheat to Portland overland. Between 50 to 100,000 bushels were freighted overland in 1874 , costing the farmers approximately 1,000 dollars in time, but costing the railroad approximately 4,000 dollars in lost freight reverue. 21 February, 1874, The Independent. Hare and other Hillsboro leaders apparently sided with the farmers on this issue, hence the town support for a planked road. Such a position may not have been in the best interest of the town's businesses. However, Hare was not regarded as a wise businessman by those who prepared the credit reports for the R.G. Dunn Company in the 1870s. He was listed as having "limited business knowledge and bad debts." R.G. Dunn \& Company Collection, Washington County, oregon, Vol. 6, 171.

$$
23427 \text { February, 1872, The oregonian. }
$$


the county government from time to time. The county court was also the civil authority for Hillsboro, as it was an unincorporated jurisdiction. Men such as Hare spoke as much for the town as they did for themselves.

The conflict between the community and railroad precluded much immedlate commercial growth in Hillsboro in the early 1870s. Hillsboro did not have a station until after 1874.238 Lot sales to the southeast of the public square along with the construction of the first school in town in the same area in 1871-72 indicates that family population was growing. Men were purchasing residential lots near a school, a sign of a family town taking shape.z30 other small signs of change can be found. The businesses of the town began to evolve, to become more specialized.237 A sense of town pride began to evidence itself, albeit in

2337 May, 1874, The Independent. It is unclear exactly when Hillsboro received its station. A newspaper article refers to wheelock simmons donating land to the town for a park near the station, which is the first reference of a station made in the press since the railroad arrived in town. Somehow simmons must have come to terms with the railroad and the station was built. simmons offer of the park may have been an attempt to make amends with the town, as he had been criticized indirectly in the papers for being "greedy and selfish" in not working with the railroad to get a station built in 1871. However, in keeping with his apparent nature, simmons donation was conditional, that is, the town had to make improvements to the park and maintain them for ten years.

230 Commissioners Journals, Vol. 3, 1869 - 1876, washington County, oregon. 7 .

23'R.E. Wiley's grocery evolved into a saloon by 1869 . Riley Cave incorporated a line of hardware into his blacksmith shop. Tobie, No Man Like Joe, 265. 
modest form. 230

The coming of the railroad afforded the agricultural community surrounding Hillsboro increased access to outside markets. Several new businesses opened in the 1870 s that reflect the limited commercial development of Hillsboro with regard to agricultural export. By 1876. John Milne, a scot, had opened the Hillsboro Mill which produced oat meal, graham flour and cracked wheat. It was the first major commercial venture related to agriculture in Hillsboro. The bulk of the mill's production was sold to san francisco. In addition, wheelock Simmons and Robert and James Imbrie, who were in partnership with J.J. Morgan, operated a 1,000 bushel capacity wheat warehouse at the oregon central depot in Hillsboro. 230

An analysis of the growth of Hillsboro's businesses in the decade of the 1870 s reveals the same general business configuration it had in the 1850s. It was a town of livery stables, blacksmith shops, mechanics, hotels, and a few

$23^{8}$ Local merchants, led by Riley cave, petitioned the County court to purchase shade trees for the courthouse square. In March 1871,64 maple trees were purchased. June Benowitz, "From Log Cabin to Highrise," Washington County Administration Building Dedication Ceremony pamphlet, 17 April, 1988, 2 .

239 oregon state Directory. (Portland, or.: J.K. Gill Publishing Co. 1881) 557. The Imbries were prominent members of the early settlement community of East Tualatin Plains. Their partnership with townsman wheelock simmons and J.J. Morgan was exceptional as one of the few such commercial ventures between the farmers of the plains and Hillsboro's townsmen between 1850 and 1880 . 
lawyers and doctors. Within these categories, there was a degree of duplication which indicates a growing cliental as the local town and farming population grew. One of the more notable aspects of the growth of new businesses in Hillsboro throughout the 1870 s was the increase in small town amenities such as barber shops, candy stores, photographers, family groceries and a jeweller. such businesses catered to a family trade. They were not components of a commercial expansion of the town. 240

The oregon State Directory of 1881 also lists five carpenters in town in comparison to only one in the $1860 \mathrm{~s}$. such a number perhaps indicates that there was a market for their labor, including residential construction. The school population of the town stood at 175 in 1881 , which would indicate a considerable growth in families in Hillsboro during the 1870s. New families require new homes.242

It seems the railroad brought more to Hillsboro than it took away. More and more families moved to Hillsboro over the years, along with small town businesses to serve them. As the growth of the family population increased, the social infrastructure attendant to a family town evolved. Two new churches were established in Hillsboro in the 1860s, along with a newspaper and the school. By the mid-1870s, the town

240oregon State Directory, 557-558.

24 Oregon state Directory, 557. The Hillsboro school was built in 1870-71. 
had a Musical Society, a brass band and an opera house. 202 The concerns of the town were not on expanded commerce but on civilizing the community by eradicating the rougher aspects of its pioneer days and making it a place safe for families. The town incorporated in october of 1876 . Incorporation as a municipality gave it a measure of legal and social control lacking under the governance of the county court. The court had jurisdiction over Hillsboro only as a part of washington county as a whole. The court was not set up to provide municipal services, such as sidewalks, lighting, nor to regulate public behavior according to small town standards.

The town Trustees were mostly lawyers, doctors and other professionals, men who prided themselves on a high moral tone. The first ordinance the Trustees passed concerned drinking and disorderly conduct. Within the first ten years of the town's incorporated history they passed eleven ordinances dealing with alcohol and public conduct related to its consumption. The balance of the ordinances dealt with public improvements and hygiene. Hillsboro was called "Sin City" because of its saloons and hard drinking male population by its more sober neighbors in Forest Grove. Forest Grove was known in turn as "Piety Hill" because of its strong religious orientation. The town fathers of

$24{ }^{2}$ R.P. Matthews, "Sin to silicon. A Brief Chronicle of the City of Hillsboro, 1850 - 1960." Mss. 298, washington County Museum, Washington County, oregon. 5-8. 
Hillsboro labored to eradicate the "Sin City" image.243

The 1886 oregon state Gazetteer and Business Directory reflects a Hillsboro little changed from that of 1880 . The population stood at 500, a gain of about 100 citizens in eight years. While that number represents a significant gain in population, it does not appear to reflect any significant increase in commerce. The town was still devoid of a bank, the nearest being in Portland. A lumber company and another flouring mill appear in the 1886 directory, a modest increase in agricultural commerce.

The proprietor of the new lumber company, J.J. Morgan, was a principal in the previously existing wheat warehouse, and railroad agent for the oregon central Railroad. He, along with the Smith brothers of the new Red Jacket Mill, appear to be the only real entrepreneurs among the town's business community. The balance of businesses listed are the same as in 1880. It was still a farm town with a modest range of business aimed at serving both the surrounding farm trade as well as the growing family population. The introduction to Hillsboro's entry in the Gazetteer speaks of such a town. It listed two churches, a good school, an efficient fire brigade and a newspaper. The commercial activities are simply listed as "farm produce and lumber is

24Matthews, "Sin to Silicon," 7-9. For example, Dick Wiley's application for a saloon license in 1877 was resisted by the town Trustees, although it was eventually granted 
shipped."244

The civilizing efforts of Hillsboro's townspeople kept pace with the modest growth of the population. New social organizations appeared in the 1870 s and $80 \mathrm{~s}$. Hillsboro possessed a lodge of the International order of Good Templars by 1873 with its own meeting hall, along with a Masonic lodge and the Grange. Hillsboro's I.O.G.T. lodge included many of the town's leading citizens, men who served on the town's Board of Trustees.24s In 1886 the Hillsboro Literary society was formed, which met in the Good Templars' Hall. The object of the society was the improvement of its members by cultivation of the liberal arts and sciences. The membership of the society was composed of all the prominent professionals and businessmen in the town, along with their wives. 240

The names of the businessmen who set the moral and social tone in Hillsboro had less and less connection with the settlement population that had inhabited East Tualatin Plains. In the 1850s, 1860 s and 1870s, there were a few men

24 oregon state Gazetteer and Business Directory, Portland (Polk and Company: 1886) 194-195.

24529 November, 1873, The Independent. Albert Tozier, Notes. Box 6 , ff 6-7, Mss. 1, washington County Museum, Washington County, oregon. The anti-alcohol ordinances passed by the Trustees are not particulariy surprising given the membership of the I.O.G.T..

$24{ }^{6}$ Records of the Hillsboro Literary society, 18861887. Mss. 371, Washington County Museum, Washington County, Oregon. 
representing families of the settlement population, such as Riley Cave the blacksmith, R.E. Wiley the saloon keeper, and Richard Baldra, who ran a hotel in town for a while in 1874 . These men were an undistinguished minority that was gradually subsumed in a business community which came primarily from outside the original settlement community. The outsiders were not radically different from the farmers. They were a small town version of the same type exhibited by the farmers of East Tualatin Plains.24

David Hill's dream was to see the oregon country fill up with several thousand farming families, just like the people he saw settling East Tualatin Plains in the late 1840s.248 The men who launched Hillsboro in the $1850 \mathrm{~s}$ did so in keeping with the town-founding trend of the gold rush era without really envisioning a major commercial center. Sulger may have wanted that, but he did not remain to lead the effort. He was gone by 1860. The failure of Hillsboro to develop for almost fifteen years after its founding no doubt discouraged any real entrepreneurs from considering Hillsboro. The townsmen of Hillsboro in the $1880 \mathrm{~s}$ pursued

24 R.G. Dunn and Company Collection, Washington County, oregon. Vol. 6, 200. The report on Baldra stated that he was previously a farmer and not much good at business. He was characterized as "hard up, slow to pay." R.E. Wiley was characterized as a drunk of limited means. R.G. Dunn Collection, Vol.6, 172. Riley Cave was portrayed as ambitious and of good character, but also of limited means. R.G. Dunn Collection, Vol. 6,186 .

248 Letter to Samual Thurston, January 6, 1850. Mss. 379, Oregon Historical Society, Portland, oregon. 
the creation of a society that had as its aim the preservation of family-oriented small town life in the midst of a farm community as envisioned by David Hill.

The small town businessmen who migrated to Hillsboro in the 1860 s and 70 s were not drawn to the town because of 1 ts potential for commercial growth but because of the lack of it. Hillsboro was a town that had failed, seemingly deliberately, to respond to Dykstra's Urban Impulse. The businessmen who set up shop in Hillsboro during this period did so because it afforded them an opportunity to do business in a manner they preferred. Hillsboro's market place threatened little competition for these men. The lists of businesses reflect this point. From the 1860 s on, the business list remains the same, one of each type of business. The only growth was duplication of business as the population grew, requiring a greater degree of service.249 The business directories show new businesses appearing only to duplicate those already in place. Older businesses remain. They are not replaced by bigger and better enterprises during these years. Hillsboro's growth was in population, not in commerce during the decades of the 1870 s and 1880 s.

The businessmen of Hillsboro were not deliberate under-

24'For example, wiley's was the only saloon in town from 1866 until 1889, when the population had doubled over the previous ten years. Ed Lyon's saloon opened in 1889 to meet the thirst of the growing population. 
achievers, nor were they ashamed of their town. The growth of Hillsboro in the 1880 s was significant. The population doubled from 500 to 1,150 . The growth of small businesses, and their attendant family cliental, eventually produced the phenomenon of town pride, or boosterism, that was a surrogate for the entrepreneurial commercialism of cities. Boosterism was a form of controlled entrepreneurialism, as it promoted the small town as a good place to live for families. By attracting families, the merchants, barbers and blacksmiths kept their trade and their preferred small town way of life. Boosterism was in effect a form of active community identity that bridged the gap between the nostalgia of the Jeffersonian agrarian dream and the reality of the hard world of commerce. 250

The appearance of boosterism in Hillsboro was apparently a facet of growth in the population. By 1889 , Hillsboro's entry in the oregon, washington and Idaho Gazetteer evidences a promotional tone lacking in previous years. Words such as "prosperous" and "progressive" are used. School population is discussed, as is a new brick bank and other brick bulldings. Five social groups are listed. The town is still characterized as primarily

$250^{\circ}$ Boosterism was a small town variation of the phenomenon of selective migration Johansen speaks of with regard to the settlement communities of the oregon frontier. In essence, these communities practiced a certain exclusivity to insure the survival of a preferred way of life. Dorothy $O$. Johansen, "A Working Hypothesis for the study of Migrations," 5 . 
agricultural in orientation. Fertile farmland is touted as moving fast. The commerce of the place is still listed as the shipping of farm produce, lumber and livestock. The impression given is that of a growing, family-oriented, farm-to-market town, a desirable place to live for those seeking a way of life that incorporates the myth of the agrarian past and the progressivism of the modern world.2si

The emergence of Hillsboro's small-town boosterism and its family town orientation in the late 1880 s is confirmed by a special edition of the Hillsboro Independent in 1891 . In this special edition, a front page article discusses in detail the town's progressive metamorphosis, especially in terms of its brick architecture, an index of prosperity in small towns 252 . The focus of the article is summed up in one sentence. "Hillsboro possesses many advantages to be considered by those who are seeking for a home, ...."

The lengthy article provides a profile of Hillsboro as having become something of a gilded lily. The town had not become the metropolis it claimed in the headlines, but rather a neater, tidier, better-built version of what it had been for the past two decades, a small farm-to-market town.

25roregon, washington and Idaho Gazetteer, 1889-90. (Portland, Or.: Polk and Company, 1890)

252 see Mumford Lewis, The Brown Decades. A Study of the Arts in America, 1865-1895. (New York: Harcourt, Brace and Co., 1931) for a discussion of the role such architecture played in the ideology of the American middle class during this period. 
The almost non-existent commerce of the town is discretely left to the last paragraph of the article, and introduced as follows. "The manufacturing industries of Hillsboro and vicinity are as yet limited." The two flour mills of earlier years are listed, along with a sash and door factory, and two brickyards -- the latter three businesses having been established to service the growing local housing market.2s3 Even more revealing is an advertisement by J.J. Morgan, the sole entrepreneur of any scale in the town for over twenty years. Morgan's advertisement promoted town lots as Hillsboro's chief money-making opportunity. Land, not commerce, is spoken of as the safe and sure way to get rich in Hillsboro. 254

Hillsboro revealed itself in 1891 to be a small town with limited aspirations. It was a careful town where businessmen who had arrived years earlier and slowly built up their positions without serious competition now ruled. Their personal values and careful business habits set the tone for Hillsboro well into the next century. Hillsboro did not fail to respond to the Urban Impulse, it chose to ignore it.

25331 December, 1891. Hillsboro Independent. 254 Ibid. 
CHAPTER IX

CONCLUSION

At the close of the nineteenth century, the people of Hillsboro were in need of reassurance. The next century promised continued social and economic changes. The community took some comfort in institutionalized nostalgia. Nostalgia for an idyllic past, the simpler days of the noble pioneer, had two attractions for the people in small towns such as Hillsboro. Nostalgia afforded a framework for putting change into perspective, and it offered succeeding generations the opportunity to assume some of the virtue of the founding generations in establishing their bona fides as native sons. In turning to nostalgia as a means of dealing with the changes inherent in the evolution of urban life, Hillsboro came full circle with the settlement community from which it grew. Instead of moving boldly forward into the future, the townsmen turned to the past for a sense of identity and direction. The pioneers of the 1840 s would have been surprised to find themselves considered the inspiration of townsmen sixty years later.2ss

25ssee Faragher, Sugar Creek, 221-222, for a discussion of the role nostalgia played in a frontier community in Illinois in the 1870s. Hillsboro's experience was very similar. 
The phenomenon of pioneer nostalgia was not limited to Hillsboro during the 1890s. It was a state-wide trend and it reflected oregon's basic conservatism, a legacy of the first settlers. Those who settled oregon in the $1840 \mathrm{~s}$ imbued the state's collective consciousness with a nostalgic, back-looking tradition that influenced rural life -- including small towns -- for much of the twentieth century. Membership in the oregon Pioneer Association, founded in 1897, was the embodiment of oregon's nostalgic orientation. Social worth was based on the date of one's arrival in oregon. 250

Many of the early settlers had been rugged individuals, trappers and subsistence-level frontier farmers. They were not much given to social elitism on the basis of origins and financial status. In celebrating the role of the pioneers in founding the Tualatin Plains community, the townsmen ignored the true nature of that community. Membership in the various nostalgic pioneer groups that sprang up in the 1880 s and 1890 s tended to be weighted in favor of the successful and the persistent. Such people read history as a legitimization of their status and existence. The past was crafted to serve the narrow needs of a successful few in the present. A mythology was created, and it served in Iieu of a genuine history for generations. The less successful, the recent arrivals in town, the ethnic immigrant, the 
itinerant, and women, all tended to be ignored by the nostalgic trend. In so doing, the townsmen sought to anchor Hillsboro as a small, family-oriented town on a selective interpretation of the settlement era. ${ }^{237}$

Hillsboro's institutionalization of pioneer nostalgia took the form of the J.S. Griffin Cabin of the Native sons of Oregon, founded in 1899. The title native son is important. Pioneers were considered as those who arrived prior to 1859 ; those who arrived after were merely early settlers. Those born in oregon were native sons. In reviewing the early officers of the Griffin Cabin, seven of the thirteen officers were not of the East Tualatin plains settlement families. They were not of the neighborhood, nor of the settlement experience. The stated aim of the group was to perpetuate the early history of oregon. In fact, much of its early activity was focused on small town society and boosterism, such as county fairs, balls, parades, bicycle tours and firemen's tournaments. In these events the officers of the cabin played a leading social role by officiating at the various events. In such a manner was history "perpetuated" in Hillsboro at the turn of the

257A case in point is J.S. Griffin and the Hillsboro Congregational church. In the 1890s the Hilisboro Congregational Church used "Father Griffin" to validate their existence and achieve celebrity status as one of the early congregations in oregon. History was written to reflect Griffin as founder of the congregation in 1842 and is so honored today. In fact, the congregation was founded in 1856 in opposition to Griffin and his over-zealous ministry. Richardson, "John Smith Griffin," 57. 
century. 258

Abner Baker, in an unpublished doctoral dissertation, investigated the pioneer tradition as it relates to the nineteenth century doctrine of progress, that is, progress as a way of explaining the westward American expansion. According to that doctrine, the pioneer equalled expansion and progress. Baker states that most of the surviving early settlers viewed themselves as progressive pioneers, that is, as first settlers who came west for progressive, positive reasons rather than the negative interpretation of the yeoman fleeing the evils of capitalism. This view of progressive pioneers was assumed in the 1870 s and thereafter, when formal pioneer organization took place. The assumption of the progressive mantel reflected the political and social trends of the era in which the organization took place. It was not an accurate recollection of the motivations behind immigration and settlement. 259

Most of those who settled at East Tualatin Plains between 1840 and 1850 fit the category of yeomen -- a figure who represented the ideals of agrarianism -- when agrarianism was threatened by a competitive market economy.

258Lester Mooberry, "Pioneers Counted from 1859 Date; First organization settlers Cited," February 15, 1962, Hillsboro Argus.

259Abner S.Baker, "The oregon Pioneer Tradition in the 19th Century: A study in Recollection and self-Definition." Ph. D. Dissertation, University of Oregon, 1968. 2-3. 
The formation of the Native sons of oregon cabin in Hillsboro in 1899 came at a time when the progressive rhetoric of the town's boosters melded with the contemporary re-interpretation of the pioneer experience. The pioneer experience was venerated by the townsmen, who in their ambitions wished the town to be associated with the recollected progressivism of the pioneers. The townsmen effectively merged their identity with that of the surrounding community composed of the descendants of the first settlers. The townsmen and the farmer became one in their need of a common nostalgia that served in lieu of a genuine history. Such a synthesis reflected Hillsboro's limited ambitions by its ideological dependance on the surrounding agrarian community.

The real motivation behind the nostalgic adaption of the virtuous pioneers by the townsmen was discomfort with the civilization of their own era. These men had a yearning for a simpler time of their own youth, when things seemed less complex, and the community was more virtuous and economically independent -- and less competitive. They disliked the multiplicity of choice in life, and the institutionalization of social and economic displacement which lessened community and, through complexity, man's own self-reliance. 200

26 Baker, "The Oregon Pioneer Tradition in the 19th Century," 83 . 
The Tualatin Plains was one of the earliest settled communities in the oregon frontier. Hillsboro was its principal town, and the county seat. Yet, from settlement to the present, little serious comprehensive historical scholarship has been carried out by the various historical groups that have existed in the town since 1899. For the most part, history has continued to be a nostalgic tool of small town boosterism, with the local historical society's floats in the town parades and their displays at the county fair.

Hillsboro's historic perspective is a confirmation of a collective self-image that is closely and sincerely held. It is a self-image born of a deliberate choice on the part of those men and women who came to town in order to live a small town version of frontier life as established at East Tualatin Plains between 1840 and 1850 . The way of life sought by the townsmen, and possessed by the farmers, could not survive the commercialization of agriculture nor the urban impulse of town development. A sub-conscious, collusive relationship grew up between farmer and townsmen to resist commercialization and protect a way of life that would insure the prolongation of the agrarian dream. It is a testament to the convictions of the community that they succeeded in so doing until well into the 1960s, when the pressures of speculative development were brought to East Tualatin Plains by the descendants of those who had elected 
to settle on other frontiers. 


\section{BIBLIOGRAPHY}

\section{Published Works}

Bailey, Barbara Ruth. Main street. Northeastern oregon. The Founding and Development of Small Towns. Portland, or.: oregon Historical society, 1982 .

Bancroft, Hubert Howe. History of oregon, Vol.II, 1848-1888. San Francisco, Cal.: The History Company, 1888.

Bechham, stephen Dow. The Indians of Western Oregon. This Land Was Theirs. Coos Bay, Or.: Argo Books, 1977.

Benson, Robert $I$. "The Glittering Plain", Land of Tualaty, Vol.1. Hillsboro, Or.: Washington County Historical Society, 1974 .

Bowen, William A. The willamette Valley. Migration and settlement on the oregon Frontier. Seattle, wa.: University of Washington Press, 1978 .

Carey, Charles H. A General History of Oregon. 2 vols. portland, or.: Metropolitan Press, 1935.

Carey, Charles $H$. The oregon constitution. Salem, or.: state Printing Department, 1926.

Curti, Merle. The Making of an American Community. stanford: Stanford University Press, 1959.

Dobbs, Caroline C. Men of Champoeg. Portland, or.: Metropolitan Press, 1932.

Dodds, Gordon B. The American Northwest. A History of oregon and Washington. Arlington Heights: Forum Press, 1986.

Faragher, John Mack. Sugar Creek. Life on the Illinois Prairie. New Haven, Conn.: Yale University Press, 1986 .

Faragher, John Mack. Men and Women on the oregon Trail. New Haven, Conn.: Yale University Press, 1979.

Galbraith, John $S$. The Hudson's Bay Company as an Imperial Factor, 1821 - 1869. Berkeley, Calif.: University of California Press, 1957. 
Genealogical Material in Oregon Donation Land Claims, Vol.1 $\& 2$. Portland, Or.: Genealogical Forum of Portland, 1957 .

Gilbert, James Henry. Trade and Currency in Early oregon. New York: AMS Press, Inc., 1967.

Holmes, Kenneth L. Covered Wagon Women. Diaries and Letters from the Western Trails, 1840-1890. Ed. K. Holmes. 4 vols. Glendale, Cal.: Arthur H. Clark, Co., 1983. Vol. $1,1840-1890$.

Jackson, W.T. Wagon Roads West. A Study of Federal Road Surveys and Construction in the Trans-Mississippi West. New Haven, Conn.: Yale University Press, 1952.

Johannsen, Robert $w$. Frontier Politics on the Eve of the Civil War. Seattle, Wa.: University of washington Press, 1955 .

Johansen, Dorothy 0 . "The Land Base of Oregon's Economy", Genealogical Materials in the oregon Donation Land Claims, Vol.II. Portland, or.: Genealogical Forum of Portland, 1959 .

Lewis, Mumford. The Brown Decades. A study of the Arts in America, $1865-1895$. New York: Harcourt, Brace and Co., 1931.

Loy, William G., et al. Atlas of oregon. Eugene, or.: University of Oregon Press, 1976.

Luckingham, Bradford. "The Urban Dimensions of Western History", Historians and the American West. Ed. Michael P. Malone. Lincoln, Neb.: University of Nebraska Press, 1983 .

Mackey, Harold. The Kalapuyans. A Sourcebook on the Indians of the Willamette valley. Salem, Or.: Mission Mill Press, 1974 .

Oregon state Directory, 1881. Portland, or.: J.K. Gill Publishing Co., 1881 .

oregon, Washington and Idaho Gazetteer, 1889-1890. Portland, Or.: Polk Publishing Co., 1890.

Pomeroy, Earl. The Pacific Slope. New York: Alfred A. Knopf, 1965 . 
Snyder, Eugene E. Early Portland. Stumptown Triumphant. Rival Towns on the willamette. Portland, Ore.: Binford \& Mort, 1970 .

Throckmorton, Arthur L. Oregon Argonauts. Merchant Adventurers on the oregon Frontlers. Portland, or.: oregon Historical society, 1961 .

Tobie, Harvey Elmer. No Man Like Joe. Portland, or.: Binford and Mort, 1949.

Victor, Frances Fuller. The River of the west. Hartford, conn.: Columbian Book Co., 1870 .

Wade, Richard $C$. The Urban Frontier. The Rise of Western Cities, $1790-1830$. Cambridge, Mass.: Harvard University Press, 1959.

winther, oscar osburn. The old oregon Country. A History of Frontier Trade, Transportation, and Travel. Stanford, cal.: stanford University Press, 1950.

Journal Articles

Burnett, Peter H. "Recollections and opinions of an old Pioneer." Oregon Historical Quarterly 5(1904): 151-198.

Gaston, Joseph. "The Cregon Central Railroad." Oregon Historical Quarterly 3(1902): 315-326.

Johansen, Dorothy 0 . "A Working Hypothesis for the study of Migrations," Pacific Historical Review 31(Feb.,1967) 112 .

Minto, John. "The Number and Condition of the Native Race in oregon When first seen BY White Men." Oregon Historical Quarterly 1(3): 296-315.

Oliphant, J. "Minutes of the west Union Baptist Church." Oregon Historical Quarterly 36(1935): 247-262.

Robbins, william G. "Opportunity and Persistence in the Pacific Northwest: A Quantitative Study of Early Roseburg, Oregon." Pacific Historical Review. 34(1970): $279-296$.

Robbins, William G. "Social and Economic Change in Roseburg, oregon, 1850-1885: A Quantitative View." Pacific Northwest Quarterly 64(1973): 80-87. 
"Slocum's Report on Oregon, 1836-37." Oregon Historical Quarterly 13(1912): 175-224.

Scott, Leslie M. "John Work's Journey from Fort Vancouver to Umpqua River, and Return, in 1834." Oregon Historical Quarterly 24(1923): 240-245.

Wardell, M.L. "Oregon Immigration Prior to 1846." Oregon Historical Quarterly 27(1926): 41-60.

Wilkes, Charles. "Report on the Territory of Oregon, 18381842." Oregor Historical Quarterly 12(1911): 269-299.

woodward, W.C. "The Rise and Early History of Political Parties." oregon Historical Quarterly 11(1910):323-354.

Manuscript collections

Balfour, Jay M. "The Portland-Tualatin Valley Plank Road." Research paper, Portland state University, 1969. Mss. 157, Washington County Museum, Washington County, cregon.

Berson, Robert L. "Aloha's Donation Claims." Mss. 220, Washington County Museum, Washington County, oregon.

Benson, Robert L. "Donation Land Claims", Mss. collection, washington County Museum, Washington County, Oregon.

Bourke, Paul F, Debats, Donald A. "The structures of Political Involvement in the Nineteenth Century: A Frontier Case." January, 1987. Mss. collection, washington County Museum, Washington County, oregon.

Dunn, R.G., and Company Collection. Baker Library, Harvard University Graduate School of Business Administration, Harvard University, Boston, Mass..

Griffin, John Smith. Record Book for the First Congregational Church of the Tualatin Plains. Griffin Papers. Mss.1075, oregon Historical Society, Portland, oregon.

Hill, David. Letters to Samual R. Thurston, 13 December. 1849,6 January, 1850. Samual R. Thurston Papers. Mss.379, Oregon Historical society, Portland, Oregon. 
Keeler, Robert $w$. "Introduction and Guide To An Existing Data Inventory of Archaeological Resources in washington county, Oregon." Cultural Resource Management Program survey report, 10 october, 1980. CRM collection, washington county Museum, washington County, oregon.

Keeler, Robert $W$. "observations and Predictive hypotheses on Archaeological site Locations, washington County, oregon." Cultural Resource Management Program, survey report, 13 october, 1980. CRM collection, washington county Museum, washington county, oregon.

Lepschat, Joseph, Mrs., Moore, A.W., Mrs. "Early settlements of Washington County." Mss. 325, washington County Museum, washington County, oregon.

Matthews, Richard P. "From Sin to silicon: A Brief Chronicle of the Evolution of the City of Hillsboro," Mss. 298, Washington County Museum, washington County, oregon.

Matthews, Richard P. "The cult of True Womanhood and Women's Associational Activities on the Tualatin Plains, 1840 1880 ," unpublished Mss..

Smith, Alvin Thompson. Diary, 1840-1853. Family Letters. Tualatin Academy Papers. Alvin Thompson Smith Papers. Mss.8, Oregon Historical society, Portland, Oregon.

Theses and Dissertations

Baker, Abner $S$. "The oregon Pioneer Tradition in the 19 th Century: A study in Recollection and Self-Definition." Ph.D. Dissertation, University of oregon, 1968.

Richardson, steve. "John Smith Griffin, Independent Missionary to the Indians and Tualatin Plains Pioneer." Master's Thesis, University of Oregon, 1986.

zenk, Henry B. "Contributions to Tualatin Ethnography: Subsistence and Ethnobiology." Master's Thesis, Portland state University, 1976.

\section{Pamphlets}

Benowitz, June. "From Log Cabin to High-Rise. The washington County Courthouse, 1849 - 1988." The Public Services Building Groundbreaking Ceremony. April 5, 1988 . 
Government Documents

Basic Data Survey of Oregon Counties, Index 35 . Oregon state Planning Board. 1938.

Board of Commissioners Journals. Washington County, Oregon. Vol. 2, 7 May, 1852 - July, 1869; Vol. 3, August, 1869 March, 1876. Washington County Museum, Washington County, oregon.

Census Records. 1845. Tualaty District. Provisional Government of oregon.

Census Records. 1850. Washington County, Oregon. United states Government.

Census Records. 1860. Washington County, oregon. United States Government.

Census Records. 1870. Washington County, oregon. United states Government.

Deed Records. Washington County, Oregon. 1849-1882. Books $C, D$, and $E$. Department of Records and Elections, Washington County Administration Building, Hillsboro, oregon.

Farnell, James E. Tualatin River Navigability Study. Division of State Lands, Salem, Oregon, 1978.

Hillsboro. Plat of Town. 1 March, 1850. Surveyor's offlce, Washington County Administration Building, Hillsboro, oregon.

Hillsboro. Plat of Town. 14 september, 1860. Surveyor's office, Washington County Administration Building, Hillsboro, Oregon.

Inventory of the county Archives of oregon, No. 34 . Washington County, Oregon. Portland, or.: Oregon Historic Records survey, works Progress Administration, 1940 .

Township one North, Range Two West; Township one North, Range Three West; Township One South, Range Two West; Township one South, Range Three West. Official plot of Survey, Cadastral Department, General Land office, United states Department of the Interior. 1851 - 1853. 
Newspapers

Oregon Spectator, 5 Feb., 1846 - 10 March, 1855.

Democratic standard, 27 sept., 1854 - 11 May, 1859.

The Independent, 15 Nov., 1873 - 15 october, 1874 .

Hillsboro Independent, 4 Aug., 1893 - 25 Dec., 1931. 